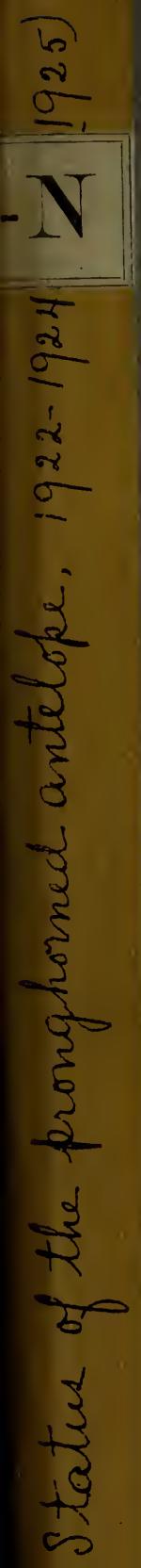




\section{HARVARD UNIVERSITY.}

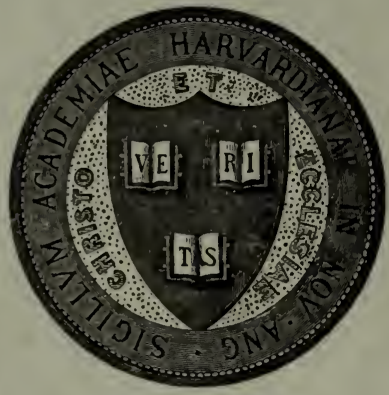

\section{LIBRARY}

OF THE

MUSEUM OF COMPARATIVE ZOÖLOGY 65.589

$$
\text { Exchange }
$$

September 10, 1925. 
UNITED STATES DEPARTMENT OF AGRICULTURE

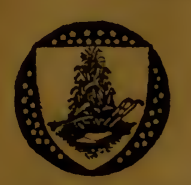

\author{
65,589 \\ DEPARTMENT BULLETIN No. 1346
}

Washington, D. C.

$\nabla$

August, 1925

\title{
STATUS OF THE PRONGHORNED ANTELOPE, 1922-1924
}

By

EDWARD W. NELSON, Chief, Bureau of Biological Survey

\section{CONTENTS}

The Pronghorned Antelope ................. Page

Former and Present Abundance of Pronghorns . . . . . . . . . . . . . . 1

Characteristics of the American Antelope. . . . . . . . . . . . . . . 4

Chosen Habitat .... . . . . . . . . . . . . . . . . . . . 7

Conservation and Control ..................... . . . . 8

Conservation Organizations and the Antelope .............. . 9

Washington Conference on the Conservation of the Pronghorn . . . . . . . . 11

Establishment of Antelope Refuges in Nevada . . . . . . . . . . . . 14

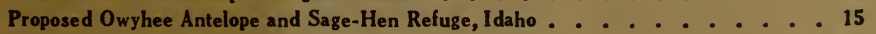

Restocking Experiments, 1924 .................. 16

Methods of Capturing and Transplanting Antelope ............. 18

Results of a Census of Existing Antelope. . . . . . . . . . . . . . . 22

WASHINGTON

GOVERNMENT PRINTING OFFICE 
Yhasion

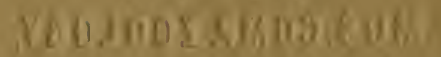
rexmotholngenges

$-$ 


\section{SEP 101925}




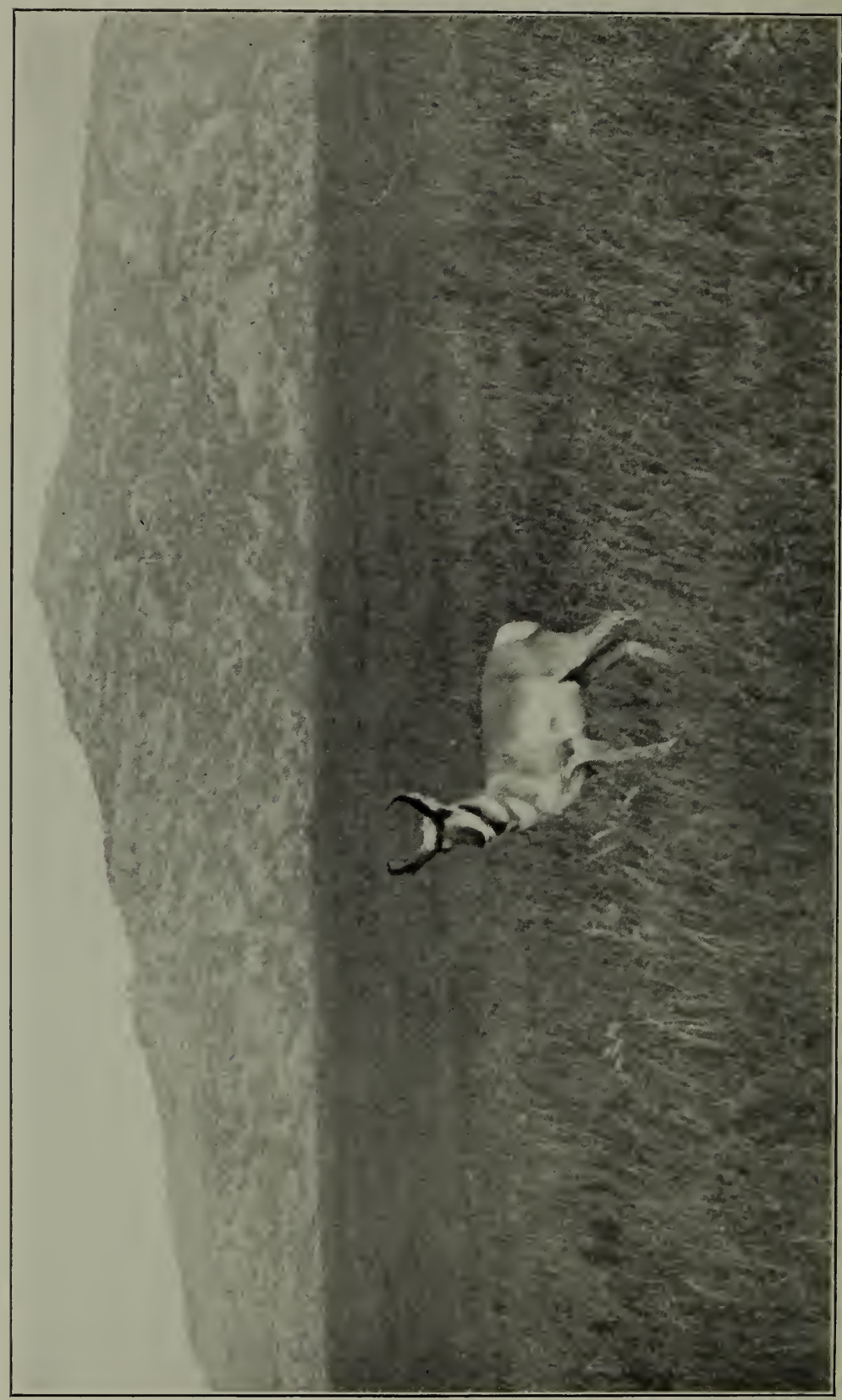




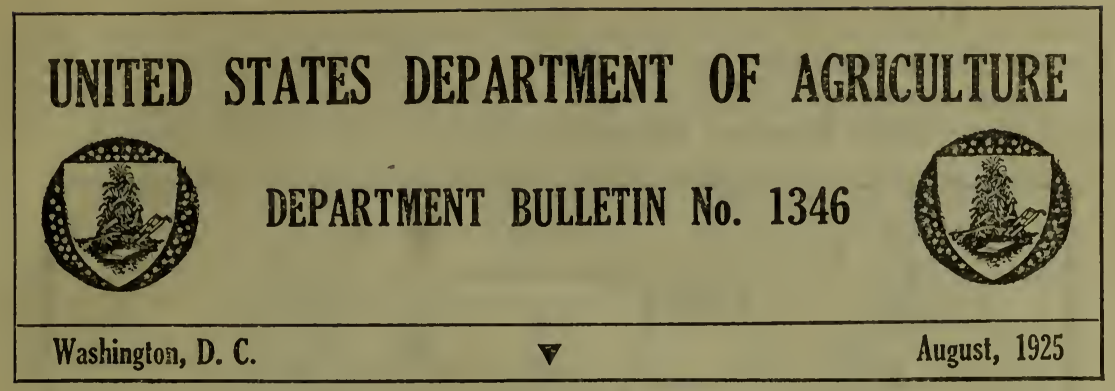

\title{
STATUS OF THE PRONGHORNED ANTELOPE, 1922-1924
}

\author{
By Edward W. Nelson, Chief, Bureau of Biological Survey
}

\begin{tabular}{|c|c|c|c|}
\hline & CONT & iNTS & \\
\hline & age & & Page \\
\hline he pronghorned antelope & 1 & Establishment of antelope refuges in & \\
\hline $\begin{array}{l}\text { ormer and present abundance } \\
\text { pronghorns }\end{array}$ & 1 & $\begin{array}{l}\text { Nevada } \\
\text { Pronosed Owyhee Anteloue and Sage- }\end{array}$ & 4 \\
\hline Characteristics of the American ante- & & lien Refuge, Idaho & 15 \\
\hline lope -- & 4 & Restocking experiments, 1024 & \\
\hline $\begin{array}{l}\text { Chosen habitat } \\
\text { Conservation and control }\end{array}$ & 8 & Methods of capturing and transplant- & 18 \\
\hline Conservation organizations and the & & Results of a census of existing ante- & \\
\hline Washingtton conference on the con- & & & \\
\hline
\end{tabular}

\section{THE PRONGHORNED ANTELOPE}

The pronghorn, or American antelope (Antilocapra americanai), is the most beautiful and graceful of America's big-game animals and has the distinction of being the only species of antelope existing in the New World at the time of its discovery by Europeans. It is not closely related to the antelopes of the Old World; but, as in the case of many other species of American mammals and birds, it was named by the early settlers from its general resemblance to the well-known Old World group. It is apparently of American origin, as shown by fossil remains of related forms. In addition, remains of species belonging to the true antelopes once inhabiting this continent have been found in fossil beds from coast to coast, some of which show remarkably close affinity to still-existing African types.

\section{FORMER AND PRESENT ABUNDANCE OF PRONGHORNS}

The first record of the pronghorned antelope having been seen by Europeans was published in 1723 in Torquemada's Monarquia Indiana, ${ }^{1}$ in which is described a great hunt made in honor of the viceroy, Antonio Mendoza, in 1540, at a place in the extreme southwestern part of the State of Hidalgo and adjoining parts of the

1 Vol. 1 , book 5, pp. 611-612. 
State of Mexico. The plain on which this hunt occurred has been known from that day to the present as the Llano del Cazadero, in commemoration of this event. The station of Cazadero on the main line of the Mexican Central Railroad marks this vicinity.

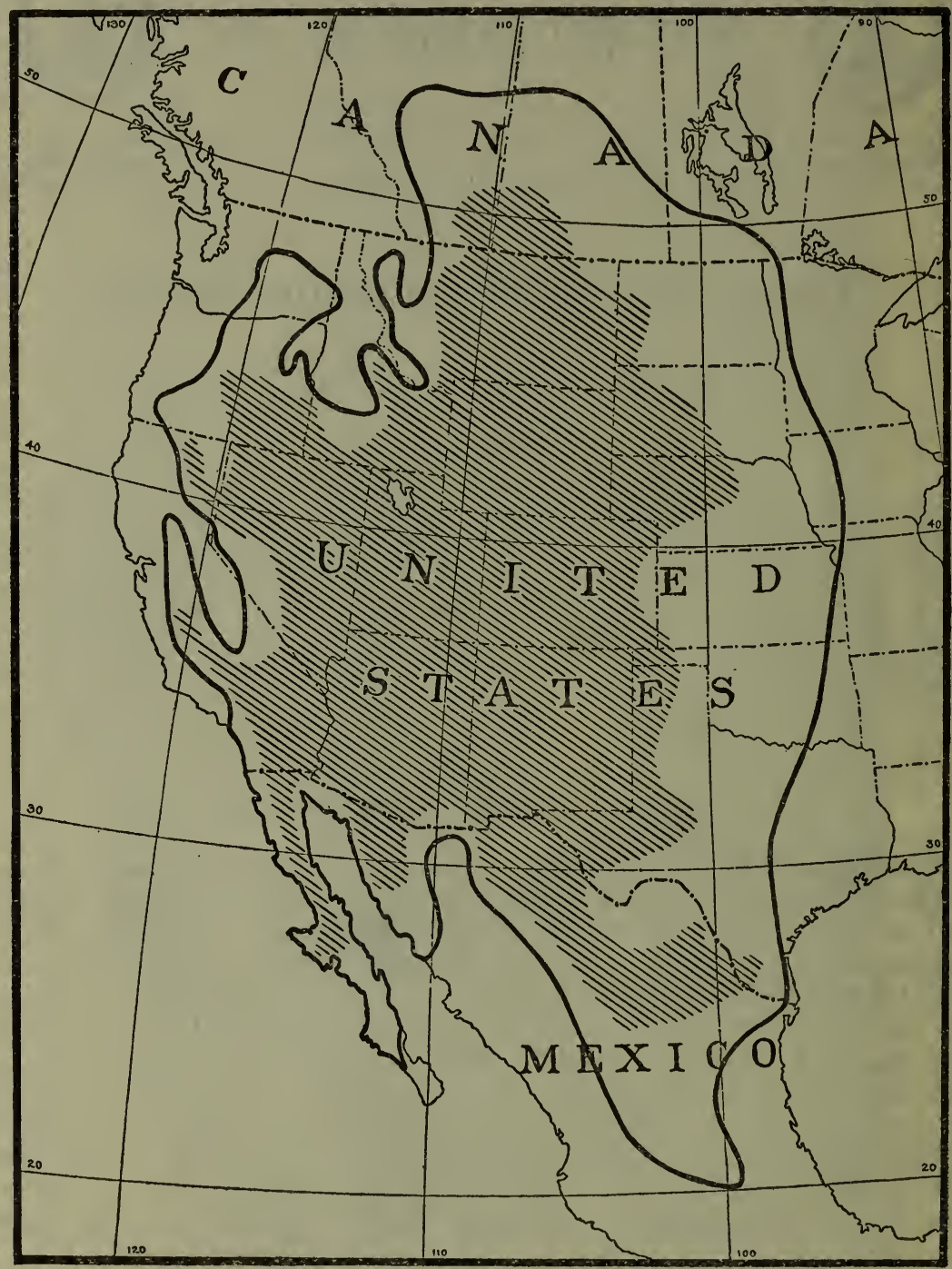

FIG. 1.-Original and present distribution of the pronghorned antelope. The black line marks the limits of the distribution before European settlements in America. The shaded portion indicates the area within which antelope are now found (1922-1924) in scattering bands. Details of present distribution within this area are shown on separate maps of States and Provinces (figs 3 to 21), and in Table 1, page 3

The hunt took the form of a great drive of game by the Indians, during which, the author states, 600 deer were killed, among which were large stags " and those which they call verrendos." He states that the verrendos did not occur in Spain, and that "they not only ran but flew," thus indicating that the remarkable speed of these 
animals attracted the attention of the first European observers. Throughout the antelope country in Mexico and the southwestern United States the Mexicans still term these animals "berrendos," the "v" of the old Spanish having been replaced by the modern "b." As a matter of course the pronghorn must have been a familiar animal to the hardy Spaniards, who overran all parts of Mexico and much of the southwestern and western United States in their search for gold, but their records of the animal life seen are exceedingly scanty.

Subsequent occupation of the continent has shown that the pronghorn ranged over an enormous area. (See map, fig. 1.) It occurred over parts of the present Provinces of Manitoba, Saskatchewan, and Alberta, in Canada. In the United States it occupied the country from western Minnesota, Iowa, Kansas, Oklahoma, and Texas, reaching the Gulf coast near the mouth of the Rio Grande, and west to eastern Washington, Oregon, and the Pacific coast in California. In Mexico it occupied the open plains country of the tableland south almost to $20^{\circ}$ of latitude, nearly to the Valley of Mexico; also the western part of Sonora and most of Lower California.

Table 1.-Distribution of antelope in North America, 1922-192/

\begin{tabular}{|c|c|c|c|c|c|}
\hline Region & Areas & $\begin{array}{l}\text { Number } \\
\text { of ante- } \\
\text { lope }\end{array}$ & Region & Areas & $\begin{array}{l}\text { Number } \\
\text { of ante- } \\
\text { lope }\end{array}$ \\
\hline $\begin{array}{l}\text { Arizona } \\
\text { California...... } \\
\text { Colorado..... } \\
\text { Idaho......... }\end{array}$ & $\begin{array}{r}18 \\
6 \\
28 \\
14\end{array}$ & $\begin{array}{r}651 \\
1,057 \\
1,233 \\
1,485\end{array}$ & \multirow{2}{*}{$\begin{array}{l}\text { Canada: } \\
\text { Alberta } \\
\text { Saskatchewan...- } \\
\text { Total, Canada }\end{array}$} & $\begin{array}{l}5 \\
9\end{array}$ & $\begin{array}{r}1,030 \\
297 \\
\end{array}$ \\
\hline Kansas.... & \multirow[b]{2}{*}{$\begin{array}{l}44 \\
10 \\
11\end{array}$} & \multirow{2}{*}{$\begin{array}{r}8 \\
3,027 \\
187 \\
4,253\end{array}$} & & 14 & 1,327 \\
\hline $\begin{array}{l}\text { Montana_-...- } \\
\text { Nebraska.-.- } \\
\text { Nevada....-.. }\end{array}$ & & & \multirow{2}{*}{$\begin{array}{l}\text { Mexico: } \\
\text { Coahuila 1 } \\
\text { Chihuahua } 1 . . . \\
\text { Durango } \\
\text { Sonora } \\
\text { Lower Californi }\end{array}$} & $\begin{array}{l}1 \\
1\end{array}$ & \multirow{2}{*}{$\begin{array}{r}600 \\
700 \\
(?) \\
595 \\
500\end{array}$} \\
\hline $\begin{array}{l}\text { New Mexico } \\
\text { North Dakota_... } \\
\text { Oklahoma.-.-.-. }\end{array}$ & \multirow{2}{*}{$\begin{array}{r}31 \\
5 \\
2 \\
4\end{array}$} & \multirow[t]{2}{*}{$\begin{array}{r}1,682 \\
225 \\
23 \\
2,039\end{array}$} & & $\frac{4}{2}$ & \\
\hline Oregon.............. & & & Total, Mexico & 8 & 12,395 \\
\hline \multirow{2}{*}{$\begin{array}{l}\text { South Dakota } \\
\text { Texas_- } \\
\text { Utah } \\
\text { Wyoming }\end{array}$} & \multirow{2}{*}{$\begin{array}{l}11 \\
42 \\
10 \\
27\end{array}$} & \multirow{2}{*}{$\begin{array}{r}680 \\
2,407 \\
670 \\
6,977\end{array}$} & \multirow{2}{*}{$\begin{array}{l}\text { Summary: } \\
\text { United States.. } \\
\text { Canada.-...... } \\
\text { Mexico }\end{array}$} & \multirow{2}{*}{$\begin{array}{r}264 \\
14 \\
8\end{array}$} & \multirow{2}{*}{$\begin{array}{r}26,604 \\
1,327 \\
12,395\end{array}$} \\
\hline & & & & & \\
\hline Total, United States & 264 & 26,604 & Grand total. & 286 & 30,326 \\
\hline
\end{tabular}

1 Estimated.

Through the occupation of its territory by man the pronghorn has become extinct in many of its former haunts, but it has survived in limited numbers over an amazing proportion of its original range in Canada, Mexico, and in 16 of the western States of this country.

Originally over most of the enormous territory occupied the pronghorn was very abundant. Its range covered not only practically all of the buffalo country west of the Mississippi River but a vastly greater area. Where the pronghorn occurred with the buffalo people best qualified to judge consider that it exceeded that animal in numbers. It has been estimated that the buffalo herds at one time numbered from thirty to sixty million animals. In view of the greater territory occupied by the pronghorn and its known abundance, it may be considered a conservative estimate to place its probable origi- 
nal numbers at not less than thirty to forty millions, and possibly more.

George Bird Grinnell informed the writer that he has often talked about the abundance of antelope with men familiar with the western plains 50 years or more ago and has never met a man of experience who did not agree with him that during the middle of the last century antelope were far more abundant than buffalo. During the summer of 1879 Doctor Grinnell found them extremely abundant in North Park, Colo., where he saw trails made by them in travel from one locality to another worn in the hard soil to a depth of from 8 to 10 inches, like the trails made by buffalo herds going to and from water or during their movements from one district to another.

As against the many millions of pronghorns once inhabiting this continent a recent census, taken through the Biological Survey and detailed elsewhere, shows approximately 30,000 survivors. (See Table 1, p. 3.)

\section{CHARACTERISTICS OF THE AMERICAN ANTELOPE}

Horns.-The pronghorn is the only antelope in the world with branched or pronged horns, and has the unique characteristic among all hollow-horned ruminants of shedding the outer covering of the horns annually. This takes place soon after the rut in November and December in the Yellowstone National Park in northern Wyoming, and elsewhere in the range of the species this time probably varies somewhat with latitude.

When the time for shedding arrives the horny sheath gradually loosens and becomes detached from the skin around the base and, following this, from the bony core within. Later the horn falls off, leaving the bony core covered with a blackish skin more or less overgrown with long, coarse hairs, which afterward are gradually lost. A new horny nucleus develops on the tip of the bony core, the horny growth then extending slowly downward until it reaches the base. Gradually thickening and hardening, the horny material grows at the tip until the new horn attains its full development. The horns continue to grow as the animal increases in age until the full size is reached.

Both sexes have horns, those on the does being smaller and slenderer than on the bucks.

Rump patch.-Another characteristic of these interesting animals is a conspicuous rump patch composed of white hairs which are longer than those elsewhere on the animal's back. Through developments in the skin muscles the pronghorn at times of excitement has the power to erect these white hairs until they stand out stiffly over the rump, forming a great dazzlingly white rosette, like a giant chrysanthemum, which, when the animal is dashing away across the plains in the bright sunlight, is extraordinarily conspicuous. The writer has many times discovered bands of antelope running on the open plains where but for these heliographic patches they would have been beyond ordinary eyesight. These long rump hairs lie like other hairs on the skin and give little indication of their strikingly conspicuous appearance until the animal suddenly throws them up into action. The antelope fawns at a very early age 
begin "flashing" their white rump patches on being startled or excited.

Curiosity.-In addition to its physical peculiarities the pronghorn is very different psychologically from any other of our large-game animals. Early in their acquaintance with these animals hunters became familiar with their intense curiosity, and have employed various methods to toll them within gunshot. One of these was to lie on the ground and wave a red flag slowly back and forth on a ramiod. Another strange performance often said to have the same effect was for a hunter to lie on his back and kick his heels in the air.

While in Mexico some years ago, during the Biological Survey zoological explorations, the writer located a considerable number of antelope on the grassy plains of northwestern Chihauhua, but found them so shy from being hunted in these open spaces that they were almost impossible of approach within gunshot. Specimens were needed for the bureau's scientific study series and every effort was made to secure them-at first, owing to the shyness of these animals, almost without success. Finally, recalling old stories of the curiosity of the antelope, the writer tried the experiment of taking a white bed sheet and, placing one edge over his head, fastened it under his chin. This formed a kind of hood, and when the two upper corners were passed under his arms and attached at the middle in the back, and the hanging edges fastened in front of his body, the whole formed a kind of hooded cloak completely covering him from head to foot. A lot of long grass stems were then gathered and stuck through his hatband so to form a tall, grassy crown.

Covered with this white cloak the writer rode out on the plains until he located a band of antelope, and when at a distance of nearly half a mile dismounted, hobbled his horse, and proceeded toward them in a stooping posture. Meanwhile they were standing looking fixedly at him. When he came within 500 yards he went on his hands and knees, the sheet covering him to the ground, and began moving slowly toward them. The antelope had lined up, with a large buck standing in front. They turned several times and nerrously ran a short distance and then turned and raced back to their first position, where they lined up to look at the strange object. The old buck of the band, which from the beginning had stood out by itself in front, began slowing walking toward him. The writer then stopped and sat with crossed legs, the cloak still hiding his person, and waited, rifle in hand, until the buck had come within 100 yards, when it became a prize for the bureau's scientific collection.

On another occasion, while clad in the same disguise, the writer saw a solitary old buck antelope standing about half a mile away on the far side of a bare, dry, alkali mud flat. He again dismounted and made a similar approach, the buck meanwhile standing and watching him steadily. The buck remained motionless and permitted the writer to continue to approach until within about 100 yards without showing any sign of alarm.

Another solitary buck grazing on an open grassy plain was approached in the same manner. Whenever it stopped grazing and looked at him intently, the writer moved his head up and down and 
sidewise as though feeding on grass and looking about and then continued to advance on hands and knees. Finally the animal stopped grazing, and when the writer was well within 100 yards it actually closed its eyes and appeared to be dozing, as its head nodded slightly up and down, apparently in complete indifference.

Through the use of this sheet the writer had no trouble in approaching antelope anywhere on the plains, and he was inclined to think that they took him for some harmless white animal. There were many half-wild cattle grazing on these plains at that time which were ordinarily shy and would run away when a man appeared on horseback. After the writer began wearing this white sheet, which not only covered himself but when on horseback would spread over the rump of the horse, the cattle ceased to show any alarm as he appeared and would permit him to ride through herds of them, merely lifting their heads and gazing at him for a short time and then resuming their feeding, the effect of the disguise apparently being the same with them as with the antelope.

It may be of interest to know that the specimens of antelope secured by the use of this grotesque disguise formed the basis of Doctor Merriam's description of a new geographic race of the pronghorn, which he named Antilocapra americana mexicana. ${ }^{2}$

Racing.-One of the most extraordinary peculiarities in the psychology of the pronghorn is its desire to pass in front of a mounted man or a team moving by at no great distance from a band. From 1883 to 1888 the writer lived in a section of Arizona where antelope were plentiful, and frequently hunted them and often saw them when riding in a wagon or on horseback along roads or trails crossing their haunts. This area was mainly covered by a great scattered forest of pinyons, cedars, and junipers, interspersed with many small grassy parks of varying size. During the summer antelope were distributed in small bands in these parks, sometimes 2 or 3 individuals together and at other times from 15 to several times that number.

It was a common occurrence when a traveler passed along these roads for a band to stand from 75 to 200 yards away watching him. Then they would suddenly start and run one after the other parallel to the course taken by the traveler and dash across the road immediately in front of him, often within a short distance, after which they would stream away and disappear among the scattered tree growth. When traveling on horseback and happening upon antelope in such places the writer often amused himself by spurring his horse to a gallop and continuing his course in a direction which would take him by and away from the animals. At such times he tried to appear unconscious of their presence, and this procedure almost invariably brought the expected response, and the animals began racing him until they had gained a slight leadership, when they would dash by in front across the road or trail, one after the other, frequently the last of the lot being within 20 yards.

Once the writer tried the experiment when he saw a solitary buck antelope stand about 100 yards to one side of a wagon road. Appearing not to notice it, he spurred his horse at full speed across

${ }^{2}$ Proc. Biol. Soc. Washington, vol, 14, p. 31, 1901; type from Sierra en Media, ("hihuahua, Mexico. 
the level plain. The buck immediately whirled and began racing him orer the grassy park, gradually drawing in until it finally crossed the trail almost under the horse's nose and certainly not more than 10 feet away, after which it dashed off and disappeared in the neighboring scattered growth of cedars.

On another occasion, after a long hunt, the writer was returning to camp just as it was becoming too dark to distinguish objects at a distance. Camp was some miles away, and in order to get there quickly he was galloping his horse down the middle of a long, narrow park in the scattered pinyon and cedar forest. He was paying no attention to anything except what lay immediately in front until a curious sound at his right caused him to look, and there he made out the dim forms of a band of about 20 antelope which, in a long line about 30 yards away, were racing him down the park. Eventually they gained sufficient headway to cross his course a short distance in front, when they disappeared. It was so dark at the time that their forms could be only dimly seen.

In discussing the pronghorn with many hunters who have been familiar with it in early days the writer has noted that without exception they have accounts illustrating the extraordinary and apparently overwhelming curiosity of these animals. This very frequently has led the animals to expose themselves to the most imminent danger. They sometimes would come almost into the midst of a camp to satisfy themselves as to the strange beings who had suddenly appeared in their territory, and many fell victims to this habit.

\section{CHOSEN HABITAT .}

The natural home of the pronghorn was on the treeless, grassy, and often desert plains of the continent. The animals would scatter singly or in small bands in spring and summer, especially during the period when the does were caring for their young fawns. As winter approached they began to gather in bands, sometimes containing thousands of individuals, and to seek favorable feeding grounds for the winter. A band of more than 500 frequented a broken and open pinyon and cedar forest in the part of eastern Arizona where the writer lived in the early eighties. In summer they broke up and scattered over the more open plains in the adjacent parts of New Mexico and northern Arizona. Numbers of them continued to reside through the year among the pinyon and cedar forests, but the bulk of the band went out on the grassy plains. In winter they were very fond of gathering in the pinyon and cedar forests, where they were sheltered from the cold storms which made the open plains places of discomfort. When within these scrubby sheltering forests they were especially liable to become victims of predatory animals and hunters. Near the base of the Sandia Mountains, in New Mexico, the writer knew of hunters trailing bands of antelope among the pinyons during long-continued snow storms and killing many of them one after the other. The animals thus falling victims to the hunter would be roughly dressed and hung up in a pinyon tree, and then the hunter would resume the trail of the survivors and in a comparatively short distance again overtake them and obtain another victim. In this way as many as 10 or 12 could be killed at times during a single morning. 
During the eighties the increase in the cattle business was so great in northern Arizona that the antelope learned many new habits. Among others was that of following range cattle through a belt of heavy pine forest up to an elevated grassy plateau of about 8,000 feet altitude, lying on the east front of the White Mountains, about the headwaters of the Black, Blue, and Colorado Rivers. There, on a wide rolling open plain, they passed the summer, coming out, on the approach of winter, in company with the cattle. This change was comparable to that which caused the elk, once a habitant of the foothills and adjacent plains, to become an animal of the higher elevations. During this period antelope became frequenters of the open, grass-grown, yellow-pine forests of the mountain areas not only in various parts of the United States but also in the Sierra Madre of Chihuahua, Mexico.

\section{CONSERVATION AND CONTROL}

The hunting of antelope is now forbidden by law almost throughout its range. In the United States, of the 16 States in which these animals still occur, Wyoming is the only one in which their hunting might be legalized. The Wyoming law authorizes the State game and fish commission to permit the killing of not to exceed 100 bucks in designated parts of the State from September 15 to October 31 in any year. In 1922 the Wyoming commission had in mind to permit the killing of 100 buck antelope under the terms of this law, but the opposition expressed by individuals and in the press, not only in Wyoming but in other parts of the country, caused the plan to be abandoned. In 1925, however, the legislature authorized the issuance of 300 such permits during October, in certain counties in the eastern and southern parts of the State.

In Nevada the close season ends in 1930, and in Kansas, by action of the 1925 legislature, the close season was extended indefinitely.

There is little likelihood that the season will be opened in any other States in the near future, although under good protection the increase of antelope in favorable areas may in a few years render it urgently necessary to reduce their numbers. With the increasing occupation of the western United States, the presence of antelope in such numbers as might occur under complete protection might create a situation that would be intolerable to some of the residents whose livelihood depends upon farming and grazing.

Antelope, as in the case of other large-game animals, when under practically complete protection, lose their fear of man to a surprising extent and become bold in raiding fields and in destroying crops. The possibility of the development of such conditions should be seriously considered by conservationists in building up herds of antelope. Efforts should be made to seek, for the establishment of antelope refuges, remote and thinly settled areas unless the animals are to be reared within fenced inclosures. Even in the latter case the increase of the animals will eventually require some control of the numbers by eliminating the surplus. This is a matter of practical game administration which should be understood and accepted by the public with the same matter-of-course attitude that is shown toward the control of the surplus livestock on a farm. The limited hunting-license system provides a practical method of handling sur- 


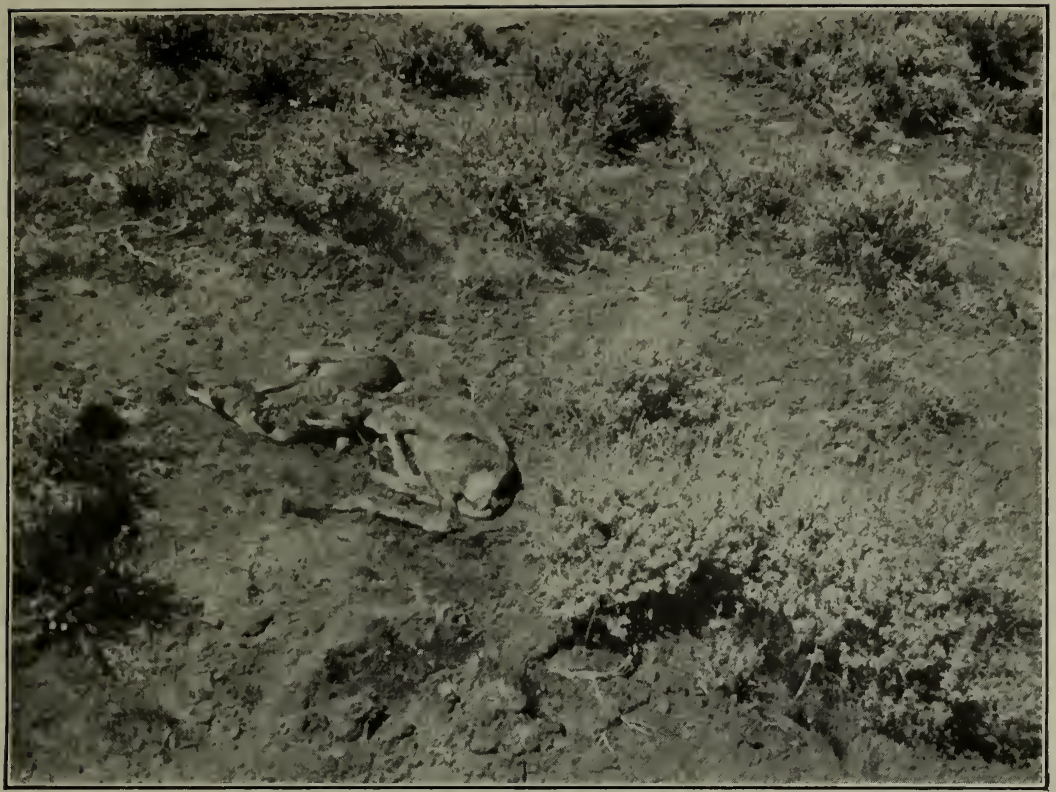

B2499M

Fig. I.-Two Newly Born Antelope, Diessner Ranch, Nev.

The doe usually hides the fawns one in a place and, feeding unconcernedly, approaches to nurse them. By watching the mothers the young animals are located and captured

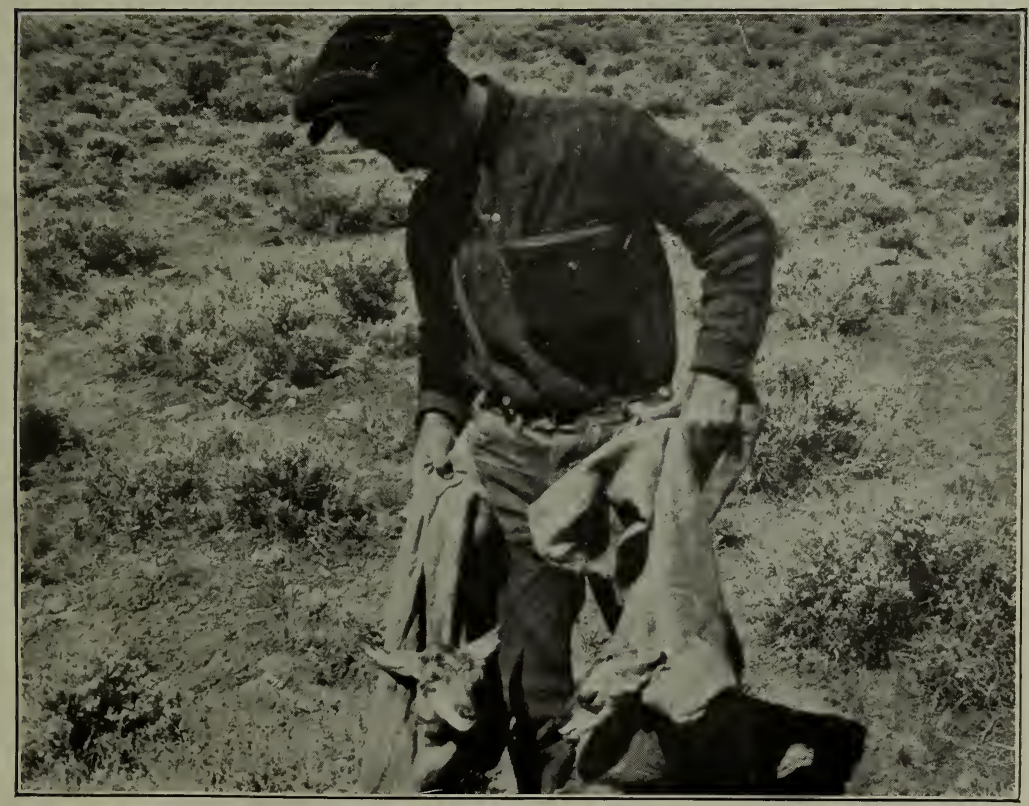

B2502M

\section{Fig. 2.-FAwns Just Captured, Washoe Rufuge, NeV.}

As soon as captured, the fawns are placed in grain sacks, each with a hole in it just large enough for the head to be put through. One sack is then hung on each side of a saddle horse and the fawns are brought to camp 


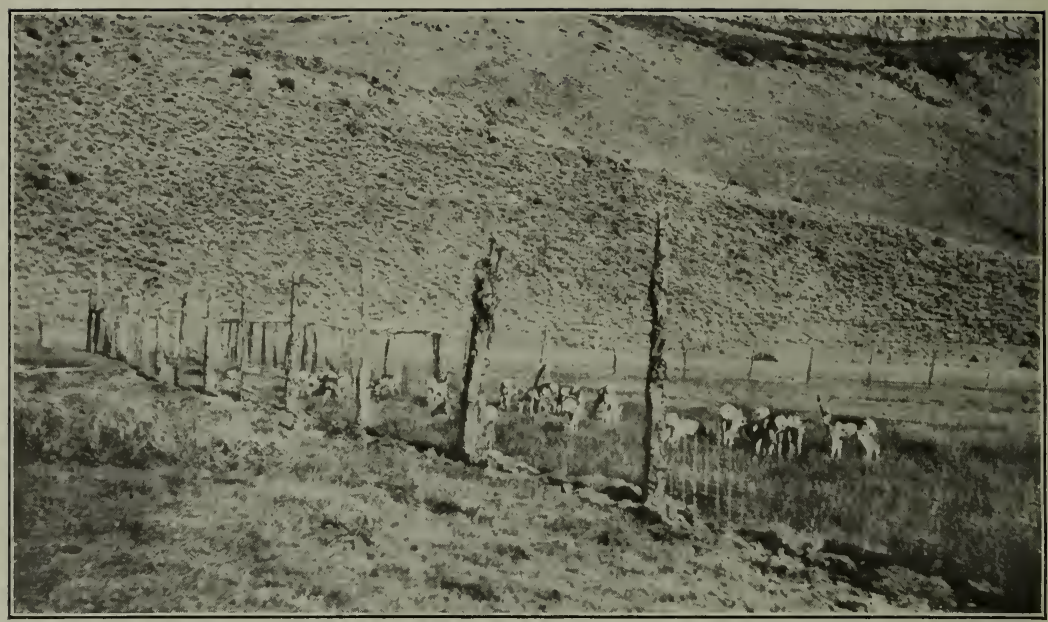

B2505 M

FIG. I.-YOUNG ANTELOPE IN TEMPORARY INCLOSURE

Captured on the Washoe Game Refuge and raised on the Wood Ranch, near Diessner, northwestern Nevada, by E. R. Sans, of the Biological Survey. Photograph taken July 18, 1924

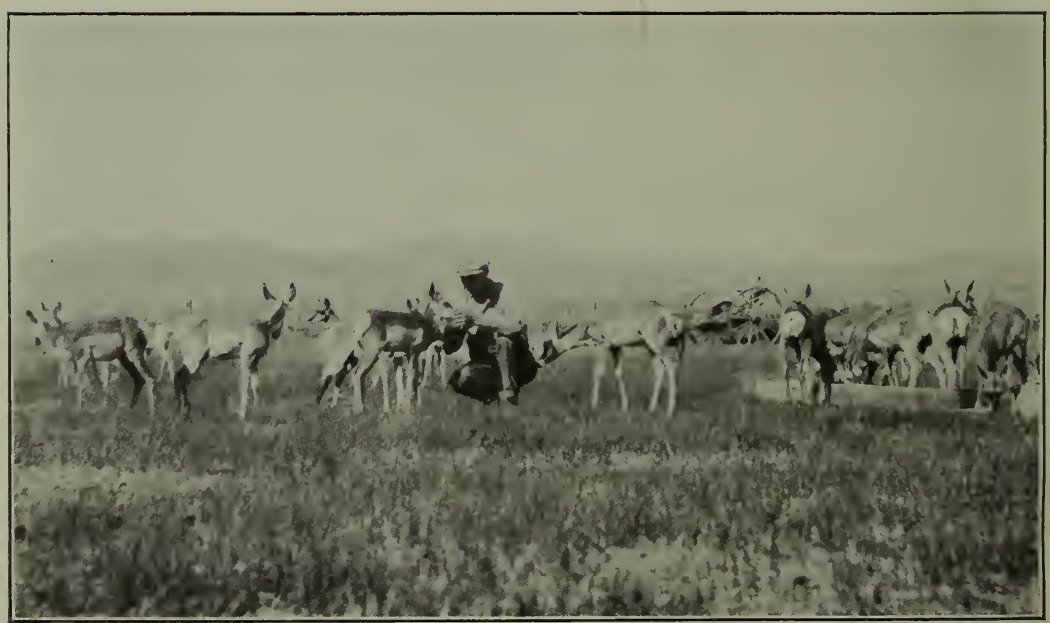

FIG. 2.-BOTTLE-RAISED FAWNS

B2503M

Photograph taken in August, 1924, on the Wood I.anch, near Diessner, Nev. 
plus game and at the same time perpetuating the species in reasonable numbers.

Conservationists should appreciate that there must be a sympathetic attitude on the part of the general public which is in direct contact with the game. This means that the surplus of big game, either of antelope or of any other kind, must be disposed of in a practical way, leaving a reasonable breeding stock to perpetuate the species. Those having administrative charge of the game in any area should determine the number of each species of large game that can properly be maintained there and provide for eliminating the surplus, if any, each year. In this manner overstocking the range and other embarrassments may be avoided.

The number of game animals of each species to be maintained in each area should be determined by a careful study of the conditions in the area by trained experts having practical knowledge of the requirements of the different species. It should be clearly understood that at the present time and for some years to come antelope need strict protection practically throughout their range, the one probable exception being in a limited area in Wyoming.

\section{CONSERVATION ORGANIZATIONS AND THE ANTELOPE}

A number of leading organizations of the country have interested themselves definitely in the conservation of antelope during a period of years. This is an appropriate place to put on record the more notable achievements of these organizations up to this time.

Boone and Crockett CTrib.-The last of December, 1910, and the first of January, 1911, 3 buck and 6 doe antelope were obtained from the Yellowstone National Park herd by the Boone and Crockett Club and shipped to the Wichita. National Game Preserve in Oklahoma, in cooperation with the United States Forest Service. (See Pl. I.) During this period 4 bucks and 8 does from the same source were shipped by this club to the National Bison Range in Montana, in cooperation with the Biological Survey. Of the antelope sent to Oklahoma, some reached their destination dead and others badly injured, and eventually all died. Those sent to the Bison Range were the basis of a herd of 64 animals which was subsequently built up and then completely destroyed by the inroads of predatory animals.

During 1914 the Boone and Crockett Club purchased 13 antelope in Alberta, which were sent to the Wind Cave National Park and Game Preserve in South Dakota. These animals did well for a time, but later their numbers had become so reduced that in 1916 the club again purchased 9 antelope in Alberta, which were placed in the same game preserve. Here they did well for a time and increased to 34 animals. Most of these were afterwards destroyed by predatory animals, but enough still remain to serve as a nucleus for building up a new herd. Special efforts are being made to protect them from further attacks by predatory animals. (Pl. VI.)

The Boone and Crockett Club appears to have been the pioneer in this line of conservation.

American Bison Society.-In January, 1912, the American Bison Society first became interested in the future of the antelope and assisted in an attempt to pass a bill through Congress to create the 
Snow Creek Antelope Preserve in Montana. In 1919 M. S. Garretson, secretary of this society, accompanied a representative of the Biological Survey to investigate conditions in southeastern Oregon for the purpose of determining the suitability of the region for the establishment of a Federal antelope refuge.

In October, 1921, the society purchased in Alberta and delivered at the Wichita National Game Preserve, Okla., 10 young antelope for the purpose of again trying to establish a herd in this locality. Most of these perished, and in 1922 the society purchased 6 additional antelope in Alberta, which were delivered at that game preserve. Most of these died; but, as is set forth in detail in the account of antelope in Oklahoma, this herd is at last increasing, with a good prospect that it may become permanently established.

During the spring of 1921 the secretary of the society accompanied a representative of the Biological Survey on an expedition to southwestern Idaho to examine that district to make recommendations concerning the establishment there of the Owyhee Antelope Refuge. The same year funds were contributed by the society to assist in protecting the Mount Dome antelope herd in California.

The annual report of the American Bison Society for 1922-23, pages 49 to 51, contains the first published census of the antelope of North America, which is dated January 1, 1922. This census was compiled by M. S. Garretson, secretary of the society, and gave a total of 11,749 antelope for the United States and Canada. The census of antelope compiled by the Biological Survey and given in detail later in this publication indicates a much greater number of antelope surviving than given in the first census mentioned above. Mr. Garretson's very creditable work was handicapped by many difficulties. The greater completeness of the census of the Biological Survey is due to the fortunate fact that this bureau has a number of employees permanently located in each of the several States where antelope occur.

The Bison Society has taken the stand that, having assured the perpetuation of the bison, it is free to help save the antelope now approaching a condition which will require active work to prevent their extermination.

Permanent Witd-Life Protection Fund.-The Permanent WildLife Protection Fund throughout its existence has taken an active interest in the conservation of antelope and has contributed substantial sums to carry out this purpose in various parts of the country. It contributed to the Bison Society funds in connection with investigations to create a Federal antelope refuge in southeastern Oregon, also for the establishment of a herd of antelope in the Wichita National Game Preserve, and for the protection of the Mount Dome herd in California. In cooperation with E. E. Brownell and the Biological Survey it assisted in the capture of 40 young antelope in northwestern Nevada during the spring of 1924 and in their distribution to the Grand Canyon National Park, Ariz.; to the Niobrara Federal Game Refuge, near Valentine, Nebr.; and to the National Bison Range, in western MFontana. It has also contributed funds to cooperate with the Biological Survey in marking the boundaries of the Washoe and Humboldt Antelope Refuges in northern Nevada. It has contributed special rewards for convictions for illegal killing of 
antelope in Oregon, and is cooperating with the Mexican Government in maintaining a special warden service to protect antelope and mountain sheep in northern Sonora. There the Mexican Government has appointed Ben H. Tinker, of Arizona, an honorary game guardian for northern Sonora. He entered on this duty on October 1, 1923, and patrols the Arizona-Sonora border during the active hunting season, October 1 to April 1, in order to enforce an executive decree protecting antelope and mountain sheep for a period of 10 years.

California Associated Societies for the Conservation of Wild Life.-This organization has interested itself in the perpetuation of the Mount Dome antelope herd. It is working with the State board of fish and game commissioners and has provided funds for feeding the animals during severe winters. It began its operations in 1914, and among its other activities materially helped in gathering information for this report concerning the distribution of antelope throughout California.

\section{WASHINGTON CONFERENCE ON THE CONSERVATION OF THE PRONGHORN}

For some years suggestions had been made that a conference be held to consider the conservation of antelope, the earlier proponents being E. Lester Jones, Director of the Coast and Geodetic Survey, Department of Commerce; Edmund Seymour, president of the American Bison Society; T. Gilbert Pearson, president of the National Association of Audubon Societies; and others.

In view, however, of the fact that a census of these animals was being taken by the Biological Survey, it was deemed best to delay such a conference until this investigation had been concluded, in order that the information obtained might be available for consideration. This census was practically completed in the fall of 1923, and a call for the antelope conference was issued by the chief of the Biological Survey to meet in the auditorium of the New National Museum, in Washington, D. C., December 14, 1923. The meeting was attended by representatives of the principal wild-life-conservation organizations of the country, State game wardens from a number of States, representatives of Government bureaus interested in wildlife conservation, and numerous private individuals. The conservation organizations and their representatives were:

Boone and Crockett Club, by Charles Sheldon; American Bison Society, by Edmund Seymour and W. T. Hornaday; Permanent Wild Life Protection Fund, by W. T. Hornaday; National Association of Audubon Societies, by T. Gilbert Pearson, W. P. Wharton, and William Finley; American Game Protective Association, by John B. Burnham; Izaak Walton League, by Will H. Dilg; Game Conservation Committee of the Camp-Fire Club of America, by W. B. Greeley and Marshall McLean; Associated Societies for the Protection of Wild Life in California, by Alden Sampson; and the National Parks Association, by Robert Sterling Yard.

Registration was made of the following State game commissions, represented by their chiefs:

Arizona, G. M. Willard; Arkansas, Lee Miles; California, F. M. Newbert; Kansas, J. B. Doze; Massachusetts, W. C. Adams; Minne- 
sota, J. F. Gould; Pennsylvania, the executive secretary, Seth E. Gordon.

The interest of the Federal Government in the conservation of the pronghorn was shown by the presence of Senator Peter Norbeck, of South Dakota, and by representation from the following Federal bureaus:

National Park Service, the director, Stephen T. Mather; Forest Service, W. C. Barnes and E. N. Kavanaugh; Coast and Geodetic Survey, the director, E. Lester Jones; and the Biological Survey, by the chief and several members of the staff. The Canadian National Parks Service, at the request of J. B. Harkin, commissioner, was also represented, O. S. Finnie, director, Northwest Territories Branch, Department of the Interior, being present.

The results of the census which had been practically completed by the Biological Survey were presented. These are set forth with some additions elsewhere in this bulletin.

From time to time during the past years the desirability has been suggested of organizing a national antelope society to foster the conservation of the pronghorn. In view of the fact that a number of the more important conservation organizations had already interested themselves and expended considerable money on projects for this purpose, it appeared to the conference that the organization of an additional conservation society would probably result in complications not beneficial to the cause and might really act as a deterrent to the development of much-needed activity to save these beautiful animals from extermination. It was agreed that the existing conservation organizations should continue to interest themselves in the conservation of the antelope as opportunity offered, and that whenever one organization should take up a specific project the others would actively cooperate in carrying it to a successful conclusion.

It was further agreed that the Biological Survey should serve as a clearing house for information concerning the pronghorn, and that its cooperation should be utilized as fully as possible in this work. The location of the Biological Survey field men engaged in predatory-animal and rodent-control work in all of the States in which antelope still exist places this bureau in a specially favorable position to procure up-to-date information on the subject. To put this decision into definite form Marshall McLean proposed a resolution for the purpose of establishing continuity of interest and activity, which was unanimously adopted by the conference, as follows:

That indiviluals and organizations represented here or others desiring to take part constitute themselves a conference for the preservation of antelope with the object of cooperating with the Biological Survey to that end.

After a discussion of many details and phases of the antelope situation and of matters connected with their conservation, T. Gilbert Pearson presented L. D. 'Frakes, owner of a cattle ranch near Warner Lake, and J. L. Lyon, owner of a sheep ranch near Lakeview, in southeastern Oregon, who came to the conference for the purpose of advocating the establishment of an antelope and sage-hen refuge covering a large area in southeastern Oregon. They announced that their ranches lie within the proposed refuge and that 
up to within a year they had been strongly opposed to its establishment; but that, after studying the matter carefully and learning the facts as to the policies that would be followed by the Government, they had become convinced that such a refuge would be to the advantage of the residents of that section of Oregon, as well as to the antelope and other wild life there.

In the discussion with these stockmen it developed that in the period when they were opposing the establishment of the refuge they believed that it would involve the elimination of livestock within the area and the destruction of their interests; but when it was understood that if such a refuge should be established there would be no elimination of the livestock of resident stock growers or other interference with their freedom beyond that of stopping the shooting of game within the area and the limitation of the number of livestock to the capacity of the forage production of the range, they approved the plan.

After discussion of the suggested antelope refuge in southeastern Oregon the conference adopted a resolution authorizing a committee made up of representatives of the conservation organizations present to meet in the offices of the Biological Survey during the afternoon of December 14 to confer with those interested and draft a bill for the creation of an antelope and sage-hen refuge in southeastern Oregon. Since then a bill has been introduced in the Oregon Legislature for the establishment of a State antelope refuge covering the area recommended.

The exclusion of hunters from the area and the prevention of destructive overstocking cover the only restrictions contemplated in the proposed Federal refuge. It was planned that the control of the grazing should be under the supervision of the Forest Service, in order to provide for the best utilization of the forage practicable.

It will be of interest to know that the first suggestion for establishing an antelope refuge in southeastern Oregon appears to have been made by L. Alva Lewis, an agent of the Biological Survey, in a letter dated January 22, 1913. In October of the same year Harry Tilford, inspector of State game refuges for the State Game Commission of Oregon, made a similar recommendation.

In 1916 E. Lester Jones, Director of the United States Coast and Geodetic Survey, made a trip into eastern Oregon, where he observed the antelope in the vicinity of Desert Lake, Jacks Lake, and Guano Lake, the principal herd being in the vicinity of Jacks Lake and containing about 800 animals. In all, he saw more than 1,000 antelope, including a number which had been apparently wantonly killed and then left to lie undisturbed where they fell. On his return from this trip Colonel Jones adrocated the establishment of a Federal antelope refuge in Lake County, Oreg., in order to try to prevent the destruction of these herds, and at the National Parks Conference held in Washington, January 4, 1917, he delivered an address on "The future of the antelope," which was printed with a map showing the proposed refuge and distributed as a circular by the National Park Service. His recommendation included the country from Hart Mountain east to the Lake County line and south to include Guano Lake. Colonel Jones warmly advocated the holding of 
the antelope conference, and still maintains a keen interest in antelope conservation.

In 1917 and 1918 representatives of the Biological Survey investigated and reported on the antelope situation in that region with a view to the possible establishment of a Federal refuge. In 1919 the secretary of the American Bison Society visited the area in company with a representative of the Biological Survey, and later recommended to his organization that it interest itself in the establishment of the proposed refuge.

Ever since the refuge was first proposed the National Association of Audubon Societies, through its Oregon representative, William L. Finley, has taken an active interest in it; and in 1923, through the efforts of the Biological Survey and the National Association of Audubon Societies, a meeting of stockmen of Lakeview was held, and favored the creation of a Federal wild-life refuge, with the understanding that local stockmen within the area should continue to retain their grazing and other rights. It was as a result of this meeting that resident stock growers attended the antelope conference in Washington, as set forth above.

\section{ESTABLISHMENT OF ANTELOPE REFUGES IN NEVADA}

In 1923 Gov. J. G. Scrugham, of Nevada, who had been empowered by the State legislature to create 25 State game refuges, requested the assistance of the Biological Survey in determining suitable locations, particularly those to be made for the protection of antelope. E. R. Sans, supervisor of predatory-animal and rodent-control work of the Biological Survey in the State, consulted with the governor, and as a result two antelope refuges were established-the Washoe State Recreation Ground and Game Refuge, lying mainly in Washoe County, in extreme northwestern Nevada, adjoining Oregon (Pl. V, fig. 1); and the Humboldt State Recreation Ground and Game Refuge, on the northern border of the State, adjacent to Owyhee County, Idaho. Following their establishment, on recommendation of Mr. Sans, who was familiar with the region, enlargements of these refuges were made by the governor to include adjacent districts specially frequented by antelope herds.

At the time of its creation the enlarged Washoe refuge was believed to contain about 2,000 antelope, and the Humboldt refuge about 1,000 . The Washoe refuge lies adjacent to that part of southeastern Oregon which for some years has been under consideration as the possible site of a Federal refuge for antelope and sage hens. 'The Humboldt refuge lies immediately to the south of that part of southwestern Idaho which also has been considered as a possible Federal antelope and sage-hen refuge. The establishment of refuges in adjacent parts of Oregon and Idaho would thus afford protection to the antelope herds passing back and forth across the border in this great tableland region, which is obviously so favorable to the perpetuation of these animals.

Predatory-animal hunters under Mr. Sans's direction had been working for a long time destroying coyotes and other stock- and gamekilling animals in the region covered by the Nevada State antelope refuges. Work for the destruction of predatory animals in these 
areas will continue and will be a great factor in lessening the losses of young antelope and in building up the herds. In addition, the Biological Survey has made an exception to its general rule and has permitted its hunters to be made deputy State game wardens, so that in carrying out their predatory-animal-control work they will be in position still further to assist in the protection of the antelope herds.

Local stockmen have shown a most friendly spirit toward the establishment of the Washoe and Humboldt refuges and have expressed a desire to assist in the protection of the antelope within these areas.

The Washoe refuge contains about 3,888 square miles, and its boundaries are about 312 miles in extent. The Humboldt refuge covers an area of 1,836 square miles, with a distance of 168 miles about its borders. At the request of the governor, the Biological Survey is taking charge of marking the boundaries of both refuges. This is rendered possible through a generous contribution of funds from the Permanent Wild Life Protection Fund, through W. T. Hornaday. Metal signs bearing the following legend are being placed on posts at suitable intervals around the borders of the Washoe refuge, and similar signs about the Humboldt refuge:

NEVADA GAME REFUGE NO. 9
For THE PRESERVATION of ANTELOPE AND OTHER GAME
HUNTING GAME ANIMALS OR BIRDS ON THIS REFUGE IS PRo-
HIBITED UNDER PENALTIES PRovidED BY LAW
All persons are asked to assist in the protection of antelope,
to prevent the extermination of this beautiful animal, found
only in North America; also to help protect other game, that
the surplus may spread to the surrounding country.
Maintained in cooperation between the State of Nevada; the
Bureau of Biological Survey, United States Department of
Agriculture; and the Permanent Wild Life Protection Fund of
New York.
For further information address.
Nevada State Game Commission, Carson City.
J. G. ScRUGHAM, Governor.

\section{PROPOSED OWYHEE ANTELOPE AND SAGE-HEN REFUGE, IDAHO}

Apparently the first suggestion that a refuge should be made for antelope and sage hens in southwestern Idaho was in a letter dated December 10, 1920, from George Tonkin, United States game warden in that region. In 1921 further information was received from Mr. Tonkin and other representatives of the Biological Survey in that area, and in the same year the American Bison Society became interested in the project, and its secretary, M. S. Garretson, visited the Owyhee region with a representative of the Biological Survey. As a result of his report and recommendations the Bison Society became active in trying to bring about the establishment of this refuge.

The stockmen resident within the limits of the proposed refuge in Owyhee County were practically a unit in its favor on the 
understanding that those operating within its limits should retain their existing rights. This, as in the case of the proposed antelope refuge in southeastern Oregon, accorded perfectly with the policy of the Biological Survey and the desires of its cooperators interested in the project.

Many antelope now exist within the limits of the proposed Owyhee refuge, as well as mule deer and other interesting mammals, and many sage hens. It is an ideal arid-region game refuge, offering sage plains varied with groups of low mountains, where considerable numbers of game animals can be maintained without in any way interfering with the grazing interests.

The sympathetic interest shown by the stockmen in this area indicates that if this refuge can be established it will give a fine demonstration of the practicability of maintaining reasonable numbers of game along with the continued use of such an area for stockgrowing purposes.

It can not be too often emphasized that it is not the policy of the Biological Survey completely to exclude grazing from game refuges except under very exceptional circumstances. This bureau is convinced that wherever a large area is involved game can be maintained there with stock without interfering with the legitimate utilization of such area for economic purposes.

It is hoped that with a better understanding of the purposes of these refuges, which are mainly to put an end to hunting game within their limits and to bring about a greater protection of game in order that it may be maintained and increase for the benefit of the surrounding region, the neighboring stockmen may come to approve their establishment. It is to be appreciated that refuges of this character should be formed in complete cooperation with the stockmen if they are to be effective.

\section{RESTOCKING EXPERIMENTS, 1924}

After a visit to the Grand Canyon National Park in northern Arizona, E. E. Brownell, of San Francisco, suggested in 1922 that the plateau midway down the slope on the south side of the canyon might well be utilized to establish a band of antelope. Following this suggestion, an expert of the Biological Survey examined the ground and found the project to be practicable. WV. T. Hornaday, of the Permanent Wild Life Protection Fund, also visited the Grand Canyon and approved the establishment of an antelope herd there. The outcome was that Doctor Brownell and Doctor Hornaday each contributed a very considerable sum to a fund to cooperate with the Biological Survey to carry out the project.

At first it was planned to purchase the young antelope for restocking purposes from Alberta, but later the Governor of Nevada, in recognition of the cooperation of the Biological Survey in the establishment of the State antelope refuges in the northern part of the State, very generously granted a permit for the bureau to capture 40 antelope fawns on the Washoe State Game Refuge. Fortunately O. C. Wood, one of the predatory-animal hunters of the Biological Survey, owned a ranch in the midst of the area occupied by the great antelope herds of that region, which was an ideal place 


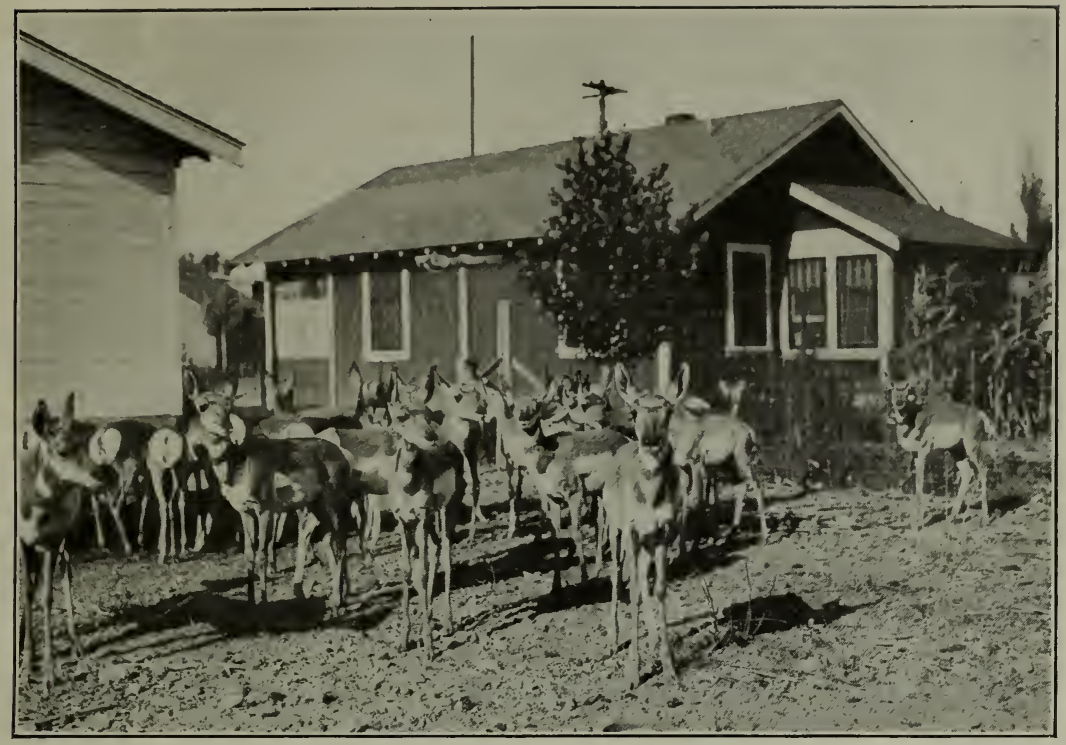

FIG. I.-ANTELOPE FAWNS IN INCLOSURE

B2517M

Photograph taken September 4, 1924, in a wire-fenced inclosure built for captured fawns, adjoining a house in Reno, Nev., where the young antelope were held for one month with complete success

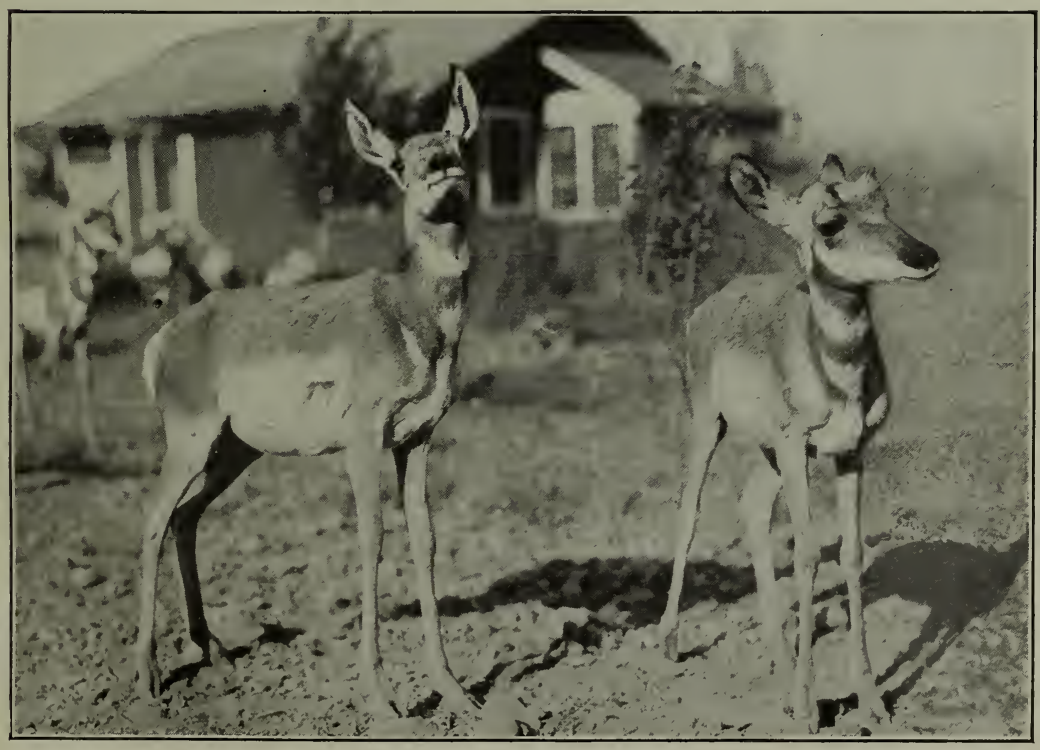

FIG. 2.-YOUNG BUCK AND DOE

$82515 \mathrm{M}$

Two members of the band of fawns shown above. The doe, about 15 weeks old, shows no horns as yet (September 4 ) 


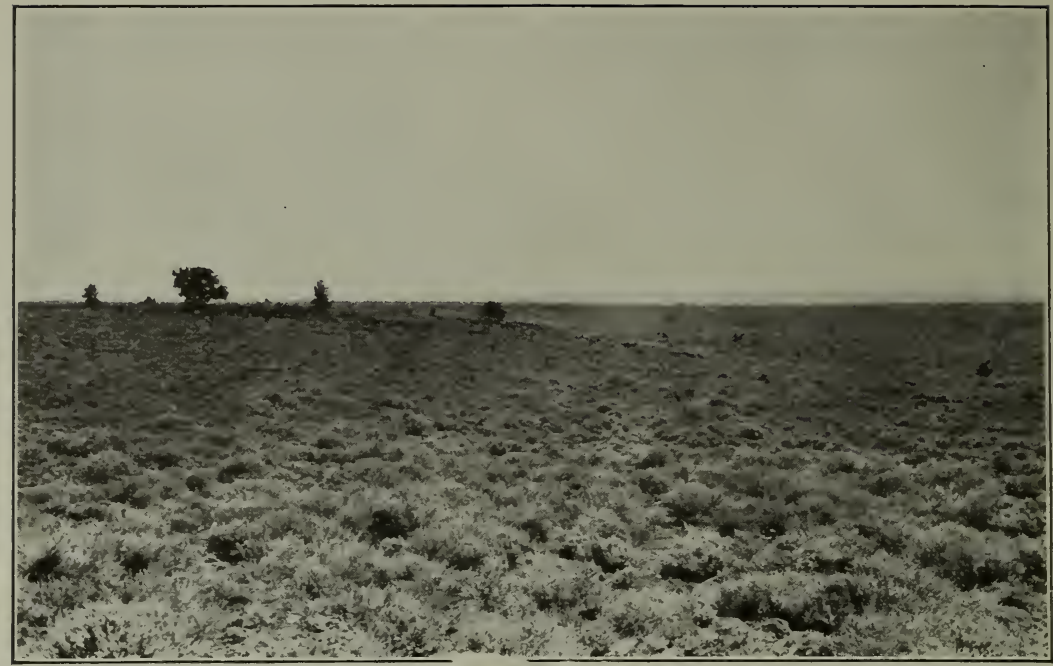

Fig. I.-View on Washoe Game Refuge, Nev.

B2500M

Photograph taken in the spring of 1924 on the antelope plain in northwestern Nevada. Typical antelope range, the vegetation consisting of sagebrush, with some low grasses and herbs

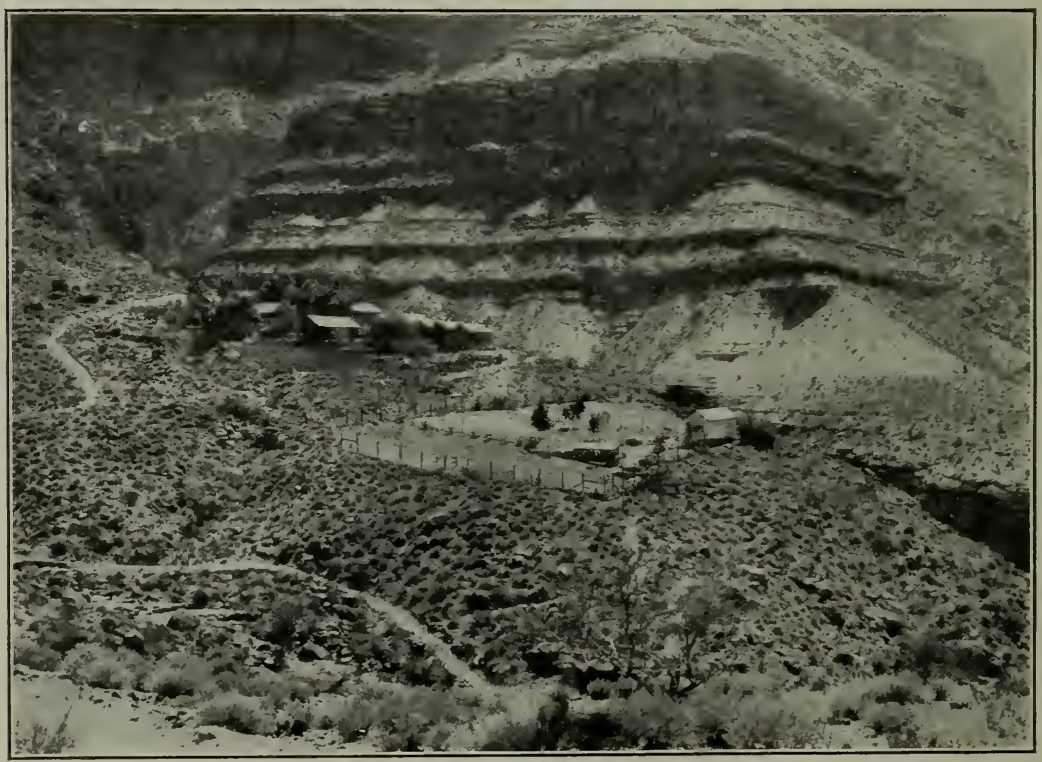

FIG. 2.-HOME OF ANTELOPE IN GRAND CANYON, ARIZ.

Hermit Creek Camp, where 11 young antelope were placed by the Biological Survey in September, 1924. Here they were fed at first by the National Park Service and are proving a great attraction to tourist visitors 
to concentrate and care for the young animals when captured and to raise them on the bottle.

This new plan of operations was submitted to the donor's of the fund and heartily approved. Its practical execution was placed in the hands of E. R. Sans of the Biological Survey.

Forty newly bor'n fawns were captured in the spring of 1924 by Mr. Sans, and all but a small number were safely reared during the summer and distributed in fall, as detailed below.

'The outcome of this experiment has been the placing of 12 antelope in Hermit Basin, in the Grand Canyon National Park, Ariz., where it is hoped they may thrive and increase so as to give pleasure to many thousands of visitors during the coming years. (I'l. V, fig. 2.) Ten of the young antelope were placed on the Niobrara reservation, near Valentine, Nebr., 9 on the National Bison Range, in western Montana, for the purpose of attempting to build up herds of these animals on both of these Federal game refuges, and 2 in the city park at Reno, Nev.

It is obvious that, following Mr. Sans's methods, the capture of young antelope would be perfectly simple in southeastern Oregon, in various parts of Wyoming, and ir wner districts where considerable numbers of these animals still exist, especially in areas like the Greybull River section of Wyoming, where they have increased until they are looked upon with disfavor by many of the resident farmel's.

To perpetuate antelope under fence, even in game refuges covering large areas, experience has shown that very great precautions must be taken first to destroy predatory animals, as bobcats and coyotes. Antelope within such areas appear to lose their freedom of movement and become extraordinarily helpless. This is particularly the case during heavy snowstorms, when they remain within more or less definite areas, in which predatory animals capture them with surprising ease.

The antelope herds in the Wind Cave Game Preserve in South Dakota and on the National Bison Range in Montana, the latter area consisting of more than 18,000 acres under fence, were brought up to a total of about 100 animals. Predatory-animal hunters had been detailed repeatedly by the Biological Survey to kill coyotes and bobcats in and about these refuges until the number of animals thus destroyed amounted to several hundred. Notwithstanding: this, however, during severe winter storms in two seasons the band of 64 antelope on the Bison Range was completely destroyed by wandering predatory animals, which were able to drive them into snow drifts and kill them without difficulty. More than half the herd on the Wind Cave refuge also was killed, partly by coyotes and partly by bobcats.

Evidence as to the danger from the bobcats was made plain when the Biological Survey warden, riding through the open pine forest of the Wind Cave refuge during a snowstorm, found and followed the fresh trail of a solitary old buck antelope. He soon came upon the tracks of a bobcat which had taken up the trail also. A short distance beyond he found the antelope, just killed and still warm. It was a full-grown buck in good condition and apparently had been easily killed by the bobcat, which had leaped upon its back. $44349^{\circ}-25-3$ 
The difficulties which have attended the establishment of a band of antelope on the Wichita fenced game preserve are detailed elsewhere in this bulletin.

With the reintroduction of antelope on the Bison Range from the Nevada fawns, the placing of a small band on the Niobrara Reservation, and the additions to the band still existing on the Wind Care Refuge by the Biological Survey, and those on the Wichita Game Refuge by the Forest Service, and in the Grand Canyon and in the Yellowstone National Parks by the National Park Service, the Federal Government is now attempting to build up herds of pronghorns in sir widely scattered localities within the limits of their former range.

\section{METHODS OF CAPTURING AND TRANSPLANTING ANTELOPE}

The following statement by E. R. Sans, supervisor of predatoryanimal-control work of the Biological Surver in Nevada, who successfully directed the capture and rearing of the 40 young antelope in northwestern Nevada during the spring of 1924 , contains so interesting and straightforward an account of the methods followed that it should enable anvone to repeat the operations successfully wherever any considerable number of antelope occur:

In the northern part of Washoe County, where we captured the young antelope farns, I estimate that there were from 1,000 to 2,000 antelope ranging during the sear except in the winter months. During the fall of 1923 they began learing this range the latter part of Norember and began returning the first of March, 1924. During December, January, and February they ranged in the High Rock Canyon country, about 40 or 50 miles south of their summer range.

In a letter receired early in Mav, 1925, Mr. Sans sums up his latest impressions concerning the antelope of this section as follows: The bunch at Last Chance, where re took the fawns last year, generally leare the plateau country about the last of Norember and work both wars, north and south, part of them going down into Guano Valles along the Oregon border and, I believe, crossing into Oregon, and the others south domn the High Rock close to the Black Rock Desert. The large bunch that ranges during the summer east of Guano Valles, in the high plateau country drift the same war, some going into Guano Valley and others into Virgin Valley and down toward the Black Rock Desert.

On April 18, 1924, I risited the summer range, and while riding on horseback over one of our predatory-animal trap lines I saw antelope everywhere I looked in bunches of 3 to 9 . The does were becoming hears with fawns, and I looked for them to start dropping them about the first of Mas. In order to be ready when the first fawns were dropped, I selected three men to start working on Mas 1. Thes were to establish camp at the Last Chance Ranch, orned by the Hapgood brothers, located at the head of the artelope range. o. C. Wood, Leo Weilmunster, and True Hapgood, one of the owners of the ranch, made up our crew. Thes were to ride the range each das, watching the female antelope to learn when the first roung were dropped. Thes were beginning to become discouraged when, on May 17, they discorered the first new-born fawn. On Mas 19 I arrired at the Hapgood Ranch accompanied 
by Smith Riley, in charge of reservations, Bureau of Biological Survey, and found the boys had 7 antelope fawns in one of the rooms of the house. They were awkward-looking things, all legs and ears.

\section{LOCATING AND CAPTURING FAWNS}

Our method of capturing the fawns was to ride out on the range early in the morning, keeping ourselves from view and using powerful field glasses in looking at the scattered antelope until we discovered a female that showed she had dropped her fawns. Then it was a matter of keeping hel in view until she went to feed her young, which she had hidden out, generally one in a place, possibly 75 to 100 yards apart [Pl. II, fig. 1.] Along about 8.30 to 10 in the morning she would go to water, then gradually feed back toward her fawns, never looking toward them but feeding as unconcernedly as if she were merely getting her morning's breakfast. Suddenly you would see a little speck raise up and the mother squat so that it could nurse. She would allow it to suckle a few minutes and then go on, the fawn following her until she picked up the twin. Then the same process would be repeated. The mother then would feed about possibly 20 minutes or a half hour, accompanied by the fawns, when one of them would drop down and she would lead the other about 75 to 100 yards and leave it also lying down. One particular doe that I was watching stopped suddenly and one of the fawns started running at right angles from the direction the mother was going, and when about 50 yards away dropped down as if it had been shot. The mother fed gradually on, leaving it there.

After the mother had left the immediate neighborhood of the hidden fawns we took particular care to sight up with objects so we could ride to the fawns. They were generally lying in the sun on the lava rocks with no shade to protect them, their heads stretched out on the ground, ears lying flat on their heads, and very difficult to see. They would allow us to walk up almost beside them before they would make a move. Then they would jump up and develop a wonderful burst of speed for about 30 or 40 yards, when their legs would begin to tangle up and they would fall down. 'I was successful in capturing two of them one morning, and was in doubt as to which of us was the most exhausted by the race when we both fell at the end.

As soon as the young were captured they were placed in a grain sack with a hole cut in the side about 4 inches from the bottom, just large enough for the head to be put out. [See Pl. II, fig. 2.] One was hung on each side of the saddle horse and thus carried to camp, where they were kept until a sufficient number were caught to warrant a trip to the permanent inclosure at the ranch. (Pl. III, fig. 1.)

The mothers are very suspicious and will not go near the fawns if they can see or scent a person; therefore much caution must be exercised in selecting a hiding place when watching to locate the young.

\section{FEEDING ON THE BOTTLE}

The next most important thing is food for the young. We found that to begin with, the best ration was rich cow's milk, about two-thirds of a pint at a feeding, heated to a little more than the body temperature and fed from a bottle through a nipple known as a lamb's nipple. Great care must be exercised not to overfeed. As the fawns all look alike, when you get a lot of them together it is necessary as soon as each one is fed to separate it from the others. Overfeeding will probably cause scours, which are difficult to handle.

In the raising of our $40 \mathrm{kids}$ we had only one that developed a real case of scours. While we brought it through by a liberal dose of lime water and 
castor oil, it never did so well as those that had not had it. We also found that whenever one of them looked a little dumpy, a tablespoonful of castor oil invariably brought it around within 24 hours. The warm milk was fed three times a day, 6 o'clock in the morning, noon, and 6 o'clock in the evening. (See Pl. III, fig. 2.)

\section{GRAIN AND GREEN FEED}

When the fawns were six weeks old we began to feed them a little wheat (bran and middlings) and when they were two months old quite a number were eating it. Then we substituted steamed rolled oats, which they ate readily at the same time that they were also eating considerable green feed from the meadow. When they were about $2 \frac{1}{2}$ months old the green feed dried up on account of the extremely dry season, and the fawns began to fall off in flesh, but ate about twice as mucl grain as they did when the green feed was plentiful.

When they were 3 months old we moved them to Reno, so as to be able to get green feed, as it would have been hard on them to wean them from their milk without it. They were very fond of green lawn cuttings of blue grass and white clover, and we cut it from the lawn three and four times a day, feeding it to them fresh and keeping an ample supply of rolled oats where they could go to it at all times. They did not appear to miss the milk, which was discontinued on August 25, with the exception of five or six weaklings and cripples which were fed milk until the 5th or 6th of September. Even though we had discontinued the milk, the kids began to fatten up and grow fast upon the green-feed and rolled-oats diet.

We shipped some of them on the 9th of September, when their average weight was 42 pounds, at $3 \frac{1}{2}$ months of age. They ranged in weight from about 35 up to 50 pounds each.

We purchased a bale of first-cutting, well-matured alfalfa hay, keeping a supply in the inclosure from the time they were 3 months old, and they would feed a little at a time on this, and no doubt if they did not have an ample supply of green feed they would have taken to it very readily. For a winter diet I believe well-cured meadow hay and rolled oats would be the best. In feeding alfalfa hay care slould be exercised not to get unmatured second or third cuttings, as there is danger of its causing bloating. Mr. Green, of the California Fish and Game Commission, told me that they had lost several deer and elk from allowing them to feed on green alfalfa in the field.

\section{TRANSFER TO TEMPORARY INCLOSURE}

When a sufficient number of fawns were caught to make a load they were placed in an automobile and taken to the Wood ranch at Diessner, Nev., where we had built a wire-fenced inclosure containing 5 acres of meadowland. The distance by road was about 55 miles, but going by saddle horse it was only 12 miles. It was much easier on the fawns to go in a car, even a much greater distance, than it would have been on pack horses for a shorter distance.

In building temporary inclosures to hold antelope fawns until they are old enough to transfer to their permanent homes (Pl. IV) much care should be taken to have all posts on the outside of the wire netting and all braces so placed that there will be no projections inside for the fawns to run against. The feeding corral should be small and made of dressed lumber with no cracks, or if net wire is used it should be lined inside with sacking to keep the animals from getting hurt when they become frightened. 


\section{CARE TO PREVENT FRIGHTENING}

Antelope fawns are rery panicky when something unusual occurs. The attendants must move slowly, talking to them at all times; quick movements frighten them. Upon entering the place where they are confined, if one will talk to them and be careful to move slowly, in a ferw minutes they will settle down and allow him to work among them without signs of fear. Even after they are 2 or 3 months old it is necessary to use much caution when going among them, but I noticed that the fawns usually come running to a man when they become frightened, apparently for protection. When suddenly frightened, however, they may rush at full speed into a fence without apparently seeing it. With a single exception every fawn we lost was injured or killed outright from being frightened. Two of them broke their necks by hitting the wire fence on a slant, running their noses into the mesl.

Fawns apparently have a hereditary fear of cats and $\operatorname{dog} s$, and I believe cats scare them worse than the dogs. I have been wondering if the bobcat family isn't one of their worst enemies on the range.

We found out when we crated the animals at Diessner that one must be very careful, for after a few were caught the others became frightened. At first we caught all the gentle ones, leaving the wild ones until the last. When we came to the last two, which were the wildest of all, one of them made a frantic jump at the wire fence, striking it on the slant and breaking its neck.

When we recrated them at Reno I purchased lumber and made a corral

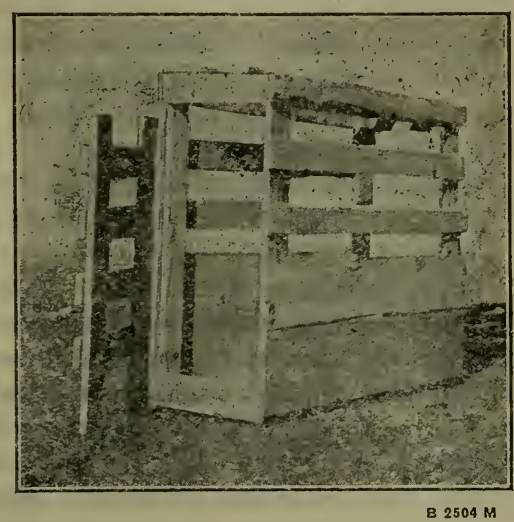

FIG. 2.- Specially constructed crate for shipping 4-months-old antelope. Made of five-eighths-inch material and requiring $201 / 3$ feet of common lumber, the inside measurements being $381 / 2$ inches long, 33 inches high, and 13 inches wide. Weight, 35 pounds. Cost of making crate and lining with burlap, including labor and materials, $\$ 2.40$ about 8 by 20 feet with a lumber chute narrowing to about 4 feet wide at oue end. Putting all the fawns into this small inclosure, we picked the wildest one first and by catching the four or five that did not come to us readily when they were out in the big inclosure we had no trouble whatever. The old gentle stand-bys did not become frightened, and within a fer minutes we had the total number for shipment crated.

\section{SHIPPING CRATES}

Crates should not be built too large. (Fig. 2.) A crate for an antelope averaging 50 pounds in weight should be about $381 / 2$ inches long, 13 inches wide, and 33 inches high, inside measurements, using select dressed lumber, about one-half or five-eighths of an inch thick by 3 inches wide. The bottom and sides up for about 12 or 14 inches should be solid, and then 3-inch strips placed 3 inches apart on the sides and ends to allow good rentilation. The two strips above the solid bottom board should be wrapped with burlap so as to make a padded crate. It is well to take a small joining plane and run over the edges of the boards so that there will be no sharp edges to cut.

The main thing in making a crate is to have it so narrow that the animal can not change ends in it. Antelope should be put in the crate backward with head toward the door. The door should be made so that it will slip in a slot 
at the bottom and then can be tied at the top with stout cord. Room for a water can and space for grain should be allowed in the front. Coarse straw at least 3 inches deep should be placed inside for a bed while in transit.

The express company charges one and one-half times the first-class rate on live animals, but does not include in the weight the feed necessary while en route. Water and feed should not be placed in the crates, therefore, until after they are weighed and billed out.

\section{TRANSPORTING ANTELOPE IN CRATES}

Animals should be crated singly, for where two or more are together they will cut each other with their sharp hoofs. When one lies down the other will invariably step on it. In the 240 miles that we transported the fawns from Diessner to Reno by automobile truck they were crated singly and endured the trip in fine shape. We left Diessner at 2 o'clock in the afternoon and, driving all night, arrived in Reno at 8.15 in the morning, thus making the trip during the coolest period of the day.

We have demonstrated beyond a doubt that young antelope can be successfully taken from their natural range and raised if care is exercised in handling them.

Great care must be taken to keep all milk containers, bottles, and nipples perfectly clean, and I would suggest that if any more antelope are taken in this district they be transferred direct to Reno as soon as the required number is captured, where unlimited supplies of milk can be obtained and also all other necessary food. It is not necessary to have such a large inclosure as we made at the Wood ranch, and I believe the antelope become gentle more readily where they see people constantly passing.

\section{RESULTS OF A CENSUS OF EXISTING ANTELOPE}

For many years the Biological Survey has been engaged in determining the former and present range of the pronghorn. In 1922 it became evident that the time had arrived for active measures leading to their conservation if their extermination was to be avoided. In order to form a basis on which intelligent conservation measures might be built a definite census of the surviving pronghorns was undertaken. This was continued from 1922 well into 1924 through field men of the Biological Survey, with the active and friendly cooperation of State game officials, State game protective associations, and individuals, not only in the United States but in Canada and Mexico, involving a great deal of correspondence.

In taking the census of the antelope in the United States the survey has been fortunate in having a field organization for the control of predatory animals and of harmful rodents in each of the 16 States where the pronghorn still occurs. Their operations in these services are of State-wide character and are conducted in cooperation with the State extension services, State departments of agriculture, and other organizations, as well as stockmen and farmers. Their work puts them in touch with county agents, sheriffs, and other officials, hunters, and men generally familiar with the State. The State game officials were particularly helpful, and the field force of the United States Forest Service also added many facts. Without the contributions from these varied sources this report could not have been prepared. Each contributor is entitled to feel that he has 
definitely assisted in a work which may be the basis for definite action in various States to insure the perpetuation of the pronghorn.

In taking this census determined efforts were made to locate as completely as possible each surviving band and, wherever possible, to have an actual count of the animals in it.

Almost throughout its range the pronghorn is decreasing. Each succeeding year some of the smaller herds marked on the accompanying maps are certain to disappear, and only in the most favorable areas, where they are carefully protected, is there hope for the lono survival of these interesting animals. In perpetuating herds of antelope in the different States one of the principal factors will be the interest taken in them by ranchmen, local sportsmen, and other residents. Antelope are on the verge of final extermination in Kansas, where in the early days they were familiar sights from the windows of passing trains.

There is little hope for the preservation of the large number of small bands containing from three to a dozen or more pronghorns. Under present conditions, when a band is reduced to a very small number, its continued existence is practically impossible unless it has the benefit of exceedingly careful guardianship.

The decrease of antelope is governed by a number of conditions, among which may be mentioned the inroads of predatory animals, illegal shooting, and the increased occupation of their territory for economic uses and the disturbance brought about by it. There may be improvement as to the first two of these factors, but the last is one which is necessarily beyond control. 'This means that eventually the surviving antelope will be limited to bands located in some of the more desert and least occupied parts of their former range, such as in northwestern Nevada, or to large, fenced game refuges. There are areas in many of the Western States which are suitable for the maintenance of bands of antelope on the open range if public sentiment will interest itself in them.

The largest herds of antelope in any restricted area appear to be located on the great plains which cover northwestern Nevada and adjacent parts of Oregon and southwestern Idaho. In this isolated, sparsely populated region may still be found the nearest approach to original conditions of any part of the antelope range in the United States to-day.

There is no intention to claim anything like complete accuracy in all the specific localities and numbers of antelope set forth. From the very nature of the case that is obviously impossible. Furthermore, with the decrease of antelope some of the small bands here listed may have already disappeared. Also occasional bands here and there may have been missed, and the numbers estimated for many may be erroneous-either too great or too small. It is earnestly desired that all who are in position to give constructive criticism will send in the information which they possess in order that corrections and additions may be made on the records.

Table 1 , on page 3 , summarizes the number of bands of antelope and the total number of animals in each within the various geographic areas. Following is a detailed statement showing the location and distribution of the bands in each of the areas listed. 


\section{ARIZONA}

In 1923 antelope in Arizona were restricted to bands occurring in 18 areas and totaled about 650 animals. A more intensire investigation might slightly increase this number. Formerly the existed in great numbers in this State, where the range and climatic conditions were peculiarly farorable to them. In the eastern part of the State from $18 S 4$ to $1 S S 9$ they were very numerous both on the grassy plains and in the parklike openings among the scattered cedar, juniper. and pinson forests corering rast areas of that great plateau region. In summer thes ranged also among the sellow-pine forests on the Mogollon Plateau, but the heary snows on these higher elerations forced them into the lower countrs in winter. As elsewhere at that period, there was no appreciation among sportsmen and the general public of the need of any restraint in killing game, and both antelope and other kinds of big game were killed freels throughout the sear. With the increasing occupation of the ranges the antelope hare steadils decreased and now are extinct orer great areas where ther once abounded.

The information concerning the number of antelope now in Arizona has come mainly from M. E. Musgrare, in charge of the predatory-animal work. and D. A. Gilchrist, of the rodent-control work, both of the Biological Surres. Their personal familiarity with all parts of the State has enabled them to make an excellent preliminars surrey of the situation. On December 15, 1923, Mr. Musgrare wrote:

"We hare collected fairls accurate data on the antelope of this State and I hare found that the number of young this rear ranges from 10 to $2 \bar{y}$ per cent of the total number of animals a year or more old. The heariest percentages of soung are on the ranges in the ricinity of Valentine, north of Seligman. It is beliered that there were 25 per cent of young born in the Sitgreares $\mathrm{Na}$ tional Forest and only about 10 per cent on the Prescott National Forest and adjacent to it. The small band located in the San Fernando Valley, south of Tucson, had an increase of about 20 per cent. The total increase for the State for the present sear should be about 15 per cent.

"The antelope that live on the Anderson Mesa hare been materially reduced in number. Last year ther numbered more than 100 head, but now only 25 surrirors are reported. I am inclined to beliere that the antelope in Arizona are increasing regardless of the rapid depletion of the herds on the Anderson Mesa, south of Flagstaff, and along the Verde rim. Antelope appear to be increasing on cattle ranges in the State and decreasing on sheep ranges."

The distribution of antelope in Arizona is approximately as follows (fig. 3) : ${ }^{3}$

1. About 12 antelope are reported as ranging in Antelope Valler, between Hurricane Ledge and Kanab Creek, north of the Grand Canyon, in Moliave Counts.

2. In 1923, according to residents of Grand Canson and railroad men emplosed on trains between Williams and Grand Canson station, in Coconino Counts, about a dozen antelope still occurred in the ricinits of Anita, or between Anita and Cataract Canjon. They are seen occasionally from the trains.

3. About 50 in small scattered bands occur in open parks in the vellow-pine forest north of Flagstaff, in Coconino Crunts.

4. Superrisor Miller, of the Coconino National Forest, reported in 1923 that the antelope ranging on Anderson Mesa, southeast of Flagstaff, in Coconino Countr. in 1913 numbered about 200 . but that in 1922 thes had become rerluced to about 100 , and in 1923 to about 25 . This decrease indicates the danger of extermination confronting this herd.

3 The paragraph numbers in this and other States and Provinces correspond to the numbered areas shown on the respective distribution maps, the numler of the area being the figure outside the circle, the number of antelope in each area leing expresied by the tigure within the circle. 

Plate Vi

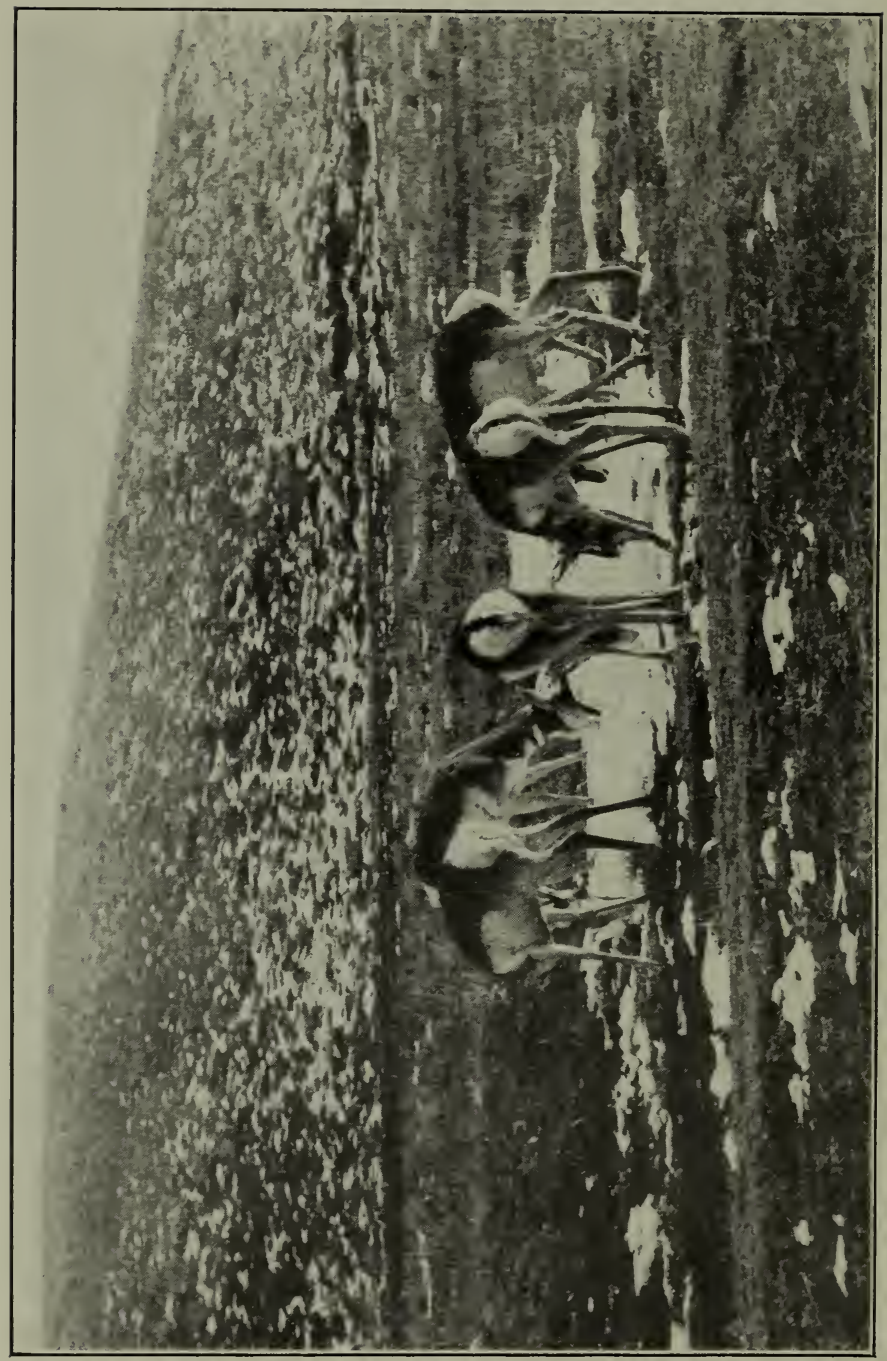

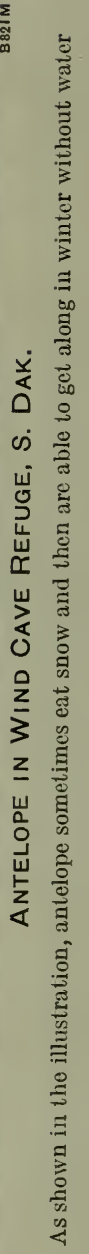


5. Formerly many antelope ranged on the sagebrush plains southwest of Winslow, in Navajo and Coconino Counties, but in 1923 these had become reduced to 10, located in Coconino County.

6. About 50 are reported on the open range near Heber, in Navajo County.

7. About 50 are reported as ranging along the Verde rim, northeast of Camp Verde, Iavapai County.

S. About 40 are ranging in Cedar Glade, south of Ashfork, in Yavapai County.

9. In 1922 several bands, aggregating 100 or more, were reported to be ranging on the Baca Grant, 50 miles south of Seligman, in Yavapai County.

10. A band of about 50 is reported as ranging in the open country near Seligman, in Yavapai and Coconino Counties.

11. In 1922 about 80 were reported to have been on the Carrow cattle range, southwest of Nelson, in Mohave County. These probably also range into Yavapai County. The Carrow brothers' give strict protection to the antelope on their range, where they have increased within the last 10 years from about 15 animals to the present number.

12. A band of 25 is reported as occupying the open range southeast of Springerville, in Apache County. From 1884 to 1890 bands aggregating 500 to 600 antelope occupied this territory.

13. In 1923 bands aggregrating about 75 antelope were reported to have been ranging in Iuma County, ne a $r^{\prime}$ the international boundary. Seven head were reported in 1924 between the Mohawk and the Cabeza Prieta ranges.

14. In 1923 Papago Indians reported that a few antelope were still ranging in Santa Rosa Valley, in Pima County, but no definite number was given.

15. In 1923 about 30 ante-

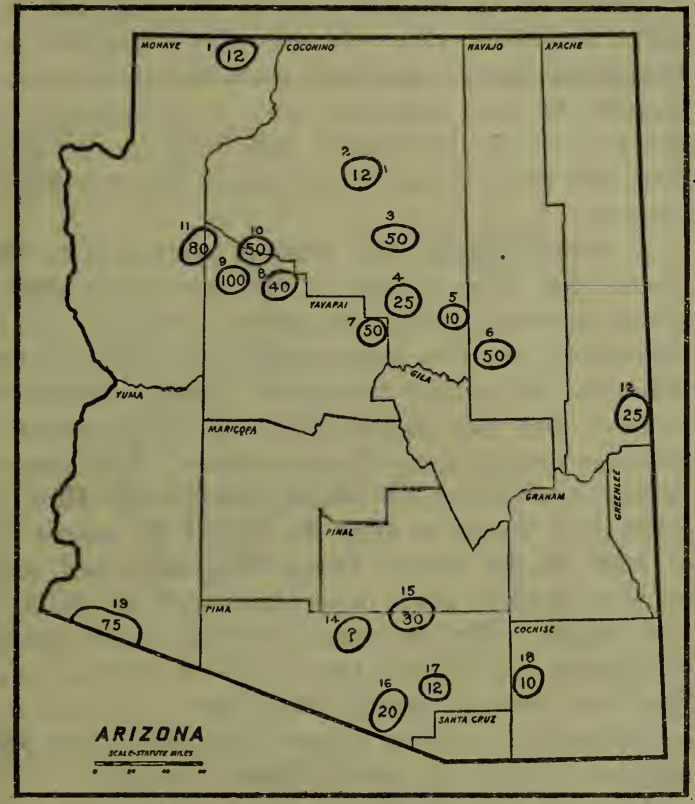

FIG. 3.-Distribution of antelope in Arizona; estimated at 651 , in 18 areas lope were reported occur-

ring on the mesa west of Oracle and along the road to Florence, about 35 miles northwest of Tucson, in Pinal and Pima Counties.

16. According to residents of Arivaca, about 20 antelope occur in the upper end of Altar Valley, not far from San Fernando Valley, in Pima County. Near a small lake near the midale of the valley in 1923 a number of young were noticed with this band, indicating that it may be slowly increasing.

17. In 1923 a band of about 12 was ranging on the plains near the north end of a small mountain range locally known as the Sierrita, southwest of Tucson, in Pima County.

18. In 1923 about 10 antelope were ranging on the plains near Benson, in Cochise County.

During the middle of the last century when the gold rush took place, antelope were generally distributed and very abundant on the plains of California, especially in the San Joaquin Valley and over the Mohave Desert region, ranging thence south to the Mexican border; also on the arid plains in the northeastern part of the State. In 1923 they had been reduced to small bands in six widely separated areas, containing a total of about 1,057 animals.

$44349^{\circ}-25-4$ 
Although the intensive occupation of California is making nearly all parts of the State impossible for the presence of antelope in a state of freedom, there are a few areas within which herds might be perpetuated, especially in the northeast. Fortunately, the State fish and game commission is taking an active interest in the matter, as is also the committee for the conservation of wild life of the California Academy of Sciences.

At the Washington Antelope Conference F. M. Newbert, president of the board of fish and game commissioners, stated that for a long time the game commission has taken an active part in trying to safeguard the surviving antelope. At one time the Mount Dome herd (No. 1 on the map) had dwindled to 11 animals. Through the interest of the commission in safeguarding these animals by its warden service the number has been increased until now there are about 118. Mr. Newbert expressed a desire to cooperate with the Biological Survey and also with the authorities of the States of Nevada and Oregon in any practical way to perpetuate and if possible increase the antelope herds. It will be difficult to perpetuate the four small herds in the southern part of the State, but in the northeast there is greater promise of success.

A correspondent who visited northeastern California in the fall of 1922 stated that three-fourths of the dry farms have been deserted in that region, which naturally tends to restore favorable conditions for the antelope. The committee for the conservation of wild life of the California Academy of Sciences has raised funds for feeding the Mount Dome antelope in severe winters and has joined with the State game commission in having game wardens protect them from poachers. It is planned to try to have an antelope refuge established for their benefit. M. Hall McAllister, chairman of that committee, wrote on July 16, 1924 : "By reason of the remarkably open winter of 1923-24 the Mount Dome herd remained scattered and did not band up as they usually have done: therefore, no tally was possible on them as has been usual. Also by reason of the small rainfall and few heavy storms in California the Lassen herds [No. 2 on the map] have migrated across the line into Nevada, and in July, 1924, not over a dozen were sighted on their old grounds in Lassen County, although some 500 are reported ranging in the neighboring part of northwestern Nevada."

No doubt the shifting of the Lassen County herds to the adjacent part of Nevada was caused by shortage of feed in the California area, and these animals may be expected to return to Lassen County as soon as adequate rainfall again restores the proper forage conditions. For this reason this herd is being credited to California, which appears to be their natural home. Fortunately, the area they have gone to in Nevada lies within the antelope refuge established in 1923 by the governor, thus affording them protection.

In California, as elsewhere, coyotes and other wild animals prey upon the diminishing herds of antelope, as upon other wild life. Wherever it is practicable the Biological Survey is having its field leaders give special attention to the destruction of predatory animals endangering the surviving herds of antelope and other large game. Hunter Fay Clark, working cooperatively for the Biological Survey and the California Department of Agriculture in the Mount Dome district, has been successful in destroying coyotes which have been preying on the antelope and deer of this district. The inroads of these pests undoubtedly account for the slow increase of this. herd. In a single month, in the range of these antelope, Mr. Clark killed 35 coyotes. The result of his work will undoubtedly become apparent in an increase of the game animals of that district, as has been the case following similar work in other parts of the West. 
The detailed information concerning the distribution and number of antelope now in California has been supplied mainly by M. Hall McAllister, of the California Academy of Sciences; George Neale, executive officer of the California Fish and Game Commission; and F. E. Garlough, of the rodent-control section of the Biological Survey.

The distribution of antelope in California is approximately as follows (fig. 4) :

1. John O. Mriller reported on February 28, 1923, that the Mount Dome herd contained about 118 antelope. They range on the plains in the southern end of Lower Klamath Lake, near Mount Dome, in Siskiyou County, probably the most favorable area in California for perpetuating antelope under natural conditions. For some years the herd has had the attention of the State fish and game commission and other conservationists, as set forth above, and with the destruction of predatory animals in that district should increase in numbers.

2. The Lassen County antelope, scattered in numerous small bands on Madeline Plains, in Dixie Valley, Secret Valley, and other points, range eastward into the Smoke Creek Desert of Nevada. These were counted by W. J. Lee, who reported on September 29, 1923, that they aggregated 864 animals. Since then it has been reported that most of these animals have crossed the State boundary into the a djacent part of Nevada, as a result of failing forage due to the excessively dry season of 1924. They will undoubtedly return with the restoration of more favorable conditions.

3. In 1922 two small bands, totaling 29 animals', were reported as ranging between Mendota and $\mathrm{Pa}$ noche Creek, on the west side of the San Joaquin

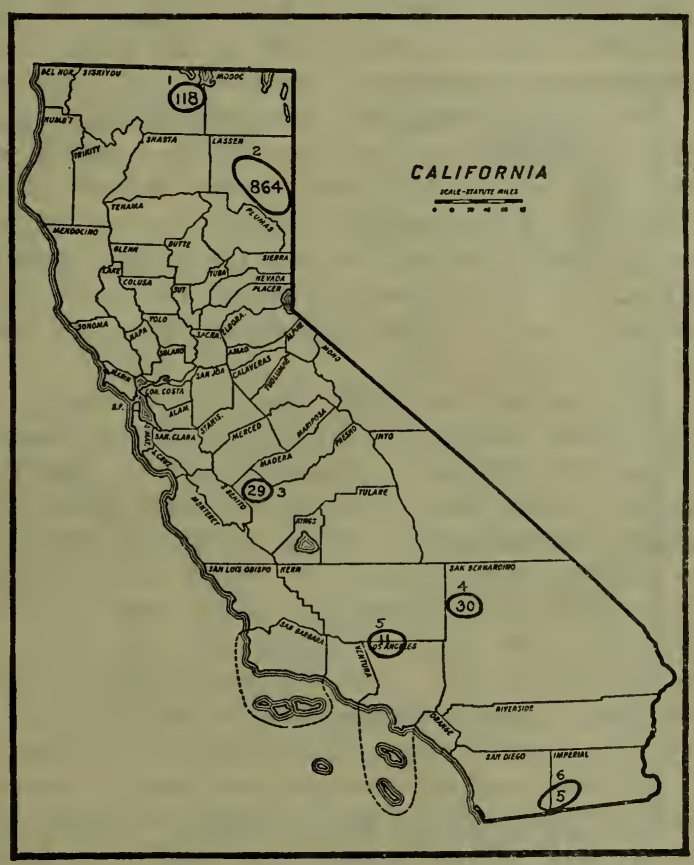

FIG. 4.-Distribution of antelope in California, estimated at 1,057 , in six areas

Valley, in Fresno County.

4. A band of about 30 was located in 1922 between Granite Wells and Randsburg, on the Mohave Desert, in San Bernardino County.

5. In 1922 a band of 11 lived in Antelope Valley on the Kern-Los Angeles refuge, ranging over adjacent parts of Kern and Los Angeles Counties. In April. 1924, 13 . were reported as having been seen between Willow Springs and Liebre Ranch, on the west side of the valley in Kern County.

6. A band of 5 was reported in 1922 ranging in the desert north of the State highway between Campo and Imperial, in Imperial and San Diego Counties. These animals probably range back and forth across the Mexican border.

\section{COLORADO}

The plains of Colorado formerly abounded in antelope. It is surprising that with the long-continued occupation of this State by farmers and stockmen bands of antelope still survived up to October, 1923, in 28 localities, aggregating approximately 1,233 animals. This indicates an interest in or at 
least a tolerance of these animals, which might well be converted into such an active spirit of protection as would perpetuate a number of herds in suitable localities.

The very excellent census of antelope in Colorado here presented is due largely to the persistent efforts of John H. Hatton, secretary-treasurer of the Colorado Game and Fish Protective Association, and to the work of Stanley P. Young and Joseph Keyes, in charge of the predatory-animal and rodentcontrol work of the Biological Survey in the State. Mr. Hatton wrote that the active interest of the Colorado Game and Fish Protective Association in the conservation of antelope will undoubtedly be very helpful in bringing about their perpetuation.

Early in 1923 the legislature of Colorado established the Colorado Antelope Refuge in northern Larimer County, on the Wyoming line, which covers the territory occupied by a band of about 75 animais. The fall of the same year Mr. Hatton wrote concerning the plans of the Colorado Game and Fish Protective Association:

"We plan during the next legislature to have presented some areas in the eastern part of the State which would be suitable for antelope refuges. We first became interested in this subject as an organization a couple of years ago, and it seemed that the first logical step would be to get a census of the species, which, as you know, has already been done. I plan also a little later to address a letter to the local newspapers where antelope are found, giving a little account of them and making appeals for their protection."

The general results of inquiries concerning antelope in Colorado indicate that these animals are steadily decreasing, especially on the eastern plains. There has been some discussion of the possibility of rounding up the survivors in this region and placing them under fence in northeastern Larimer County in the antelope refuge recently established.

Antelope once abounded in North Park, but the county assessor of Jackson County, in a letter dated October 31, 1923, stated that none remain and that the last band, containing 21, was killed many years ago by hunters from Fort Collins. About 35 years ago in that district a hunter used a, telescope rifle for killing antelope, for which he was paid $\$ 1$ each. Wagons were sent out to pick up the animals, which were shipped to Denver for sale.

The results of the census of antelope in Colorado indicate that there is still time to build up fine herds of these beautiful animals in parts of the State where they will not become obnoxious to the farmers. A careful study of the situation should be made for the purpose of locating satisfactory areas where clefinite efforts can be made to have State refuges established, and in addition of enlisting the cooperation of men having large fenced pastures to maintain small antelope herds as a matter of interest. Apparently one of the vital needs in Colorado, as in many other States, is to insure a better enforcement of the law against those who wantonly kill antelope. A large proportion of these animals now being killed are, no doubt, shot merely for passing amusement.

The distribution of antelope in Colorado is approximately as follows (fig. 5) :

1. Not less than $\mathbf{1 5 0}$ antelope range between Vermilion Creek and the head of Sand Wash in northwestern Moffat County. The majority of the people in that district seriously object to these animals being killed, although it is stated that occasionally a resident shoots one for his own use.

2. In Middle Park, northwestern Grand County, a small band of 7 still exists. This was formerly a favorite range for antelope, but they have been rapidly decreasing there and will probably be completely exterminated in the not distant future. 
3. $A$ band of about 75 is located in northeastern Larimer County, on the Colorado State Antelope Refuge, mentioned above. These antelope, no doubt, range across the boundary into southern Wyoming, and are said to be holding their own and possibly increasing. Some of the people in this district favor the protection of the antelope, while other's do not and are reported to look upon them as a nuisance.

4. About 33 antelope are reported from north-central Morgan County, where they are said to be decreasing.

5. In Logan County about 150 survive. There is some complaint here of their destroying crops. Although antelope appear to be occasionally shot in this district, the herd appears to be holding its own and with a little better protection would undoubtelly increase. It is obvious that the relation of these antelope to the farming community requires careful study before any definite effort is made to build up the herd.

6. C. F. Parker wrote from Julesburg in October, 1923, that about 55 antelope are located in the northwestern corner of Sedgwick County, where the farmer's desire their protection. In winter they come down and feed in the

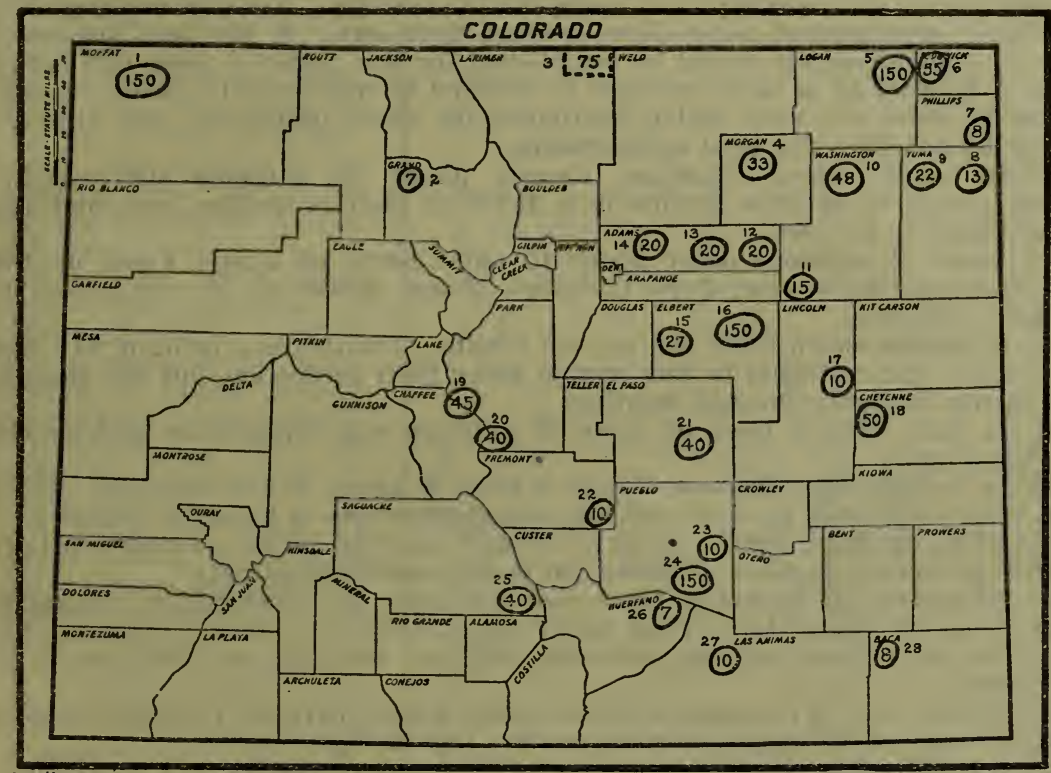

FIG. 5.-Distribution of antelope in Colorado, estimated at 1,233, in 28 areas. Antelope refuge indicated by broken lines

alfalfa fields. They are said to be increasing. Mr. Parker stated that when he fenced an 8,000-acre pasture at his Cottonwood Ranch about 20 years ago 2 does and 1 buck antelope were included. They have steadily increased since that time, and it is generally understood in the neighborhood that anyone caught molesting them will receive the limit of the law. Occasionally in that district antelope are pursued and shot by hunters in automobiles, but the resident farmers are interested in them and desire their protection.

7. A small band of eight has about held its own for several years in southeastern Phillips County. The people in that district are interested in them and favor their increase, which no doubt could be brought about by a little more careful protection.

8. A band of 13 is located in northeastern Yuma County.

9. A band of 22 is reported from northwestern Yuma County.

10. In northern Washington County, the existing herd numbers about 48, and their protection is favored by most of the people in the county, although occasionally one is shot. Suggestions have been made that they be captured and removed to a fenced refuge, but this is not generally favored. 
11. A band of about 15 has been reported from southwestern Washington County. It is stated that both this and the band in the northern part of this county are about holding their own. H. R. Rice, assessor of Washington County, wrote under date of October $2 \overline{7}, 1923$, that about two months previously 2 antelope laad been shot north of Plattner and left as they fell, and that 3 were killed in the same neighborhood a year or so before, but that efforts to locate the killers were unavailing. Mr. Rice thinks that the partial protection the antelope receive has a tendency to cause them to lose their fear of man, and this enables poachers to kill them with little difficulty. He thinks that they could best be perpetuated by inclosing them in a pasture from which each year the surplus bucks might be killed by hunters. This idea appeared to appeal to some of the local sportsmen.

12, 13, and 14. Three bands of about 20 each are reported from Adams County. It is stated that there is not much local interest in them and the herds are decreasing.

15 and 16. About 27 antelope are said to remain in the western part of Elbert County and 150 in the northeastern part. Their protection is favored by most of the people living in that district; but it is reported that they are frequently hunted, especially by men in automobiles. Notwithstanding this, the herds are reported to be about holding their own. It has been suggested that an antelope refuge might be established for the larger of these two herds.

17. A band of 10 or more antelope is reported in east-central Lincoln County. There is some not very active sentiment for their protection, and through killing by poachers the herd is decreasing.

18. In northwestern Cheyenne County about 50 antelope still remain. There is said to be little sentiment in favor of their protection, and they are being killed by hunters.

19. About 45 antelope occur about 10 miles north of Buena Vista. on the line between Chaffee and Park Counties. Local sentiment is very favorable to their protection.

20. In southwestern Park and eastern Chaffee Counties is a band of 40 . The majority of the residents in this section favor their protection, but the band is decreasing, probably through hunting.

21. In July, 1924, a hand of about 40 antelope was reported in east-central El Paso County.

22. In southeastern Fremont County a band of about 10 still survives. Their protection is farored by residents, but occasionally one is killed by hunters.

23 and 24 . In July, 1924, a band of 10 was reported in the east-central part of Pueblo County, and one of about 150 in the south-central part.

25. About 40 are reported from near Crestone, in southeastern Sagauche County, on the Luis Maria Baca grant No. 4. They are under fence in this grant and as a result of the protection they are receiving are reported to be increasing.

26. A band of 7 is reported in the extreme eastern part of Huerfano County. 27. A band of 10 ranges in north-central Las Animas County.

28. A band of 8 is reported in the northwestern Baca County.

\section{IDAHO}

Bands of antelope are reported in 14 areas in Idaho with an aggregate of approximately 1,500 animals. They are located mainly in the east-central and extreme southwestern parts of the State. Information concerning them has been obtained from R. E. Thomas, State game warden; United States Forest Superintendent Olsen; and L. J. Goldman, leader of the Biological Survey's predatory-animal work in the State.

During the past four years considerable work has been done to bring about the establishment of a Federal antelope and sage-hen refuge, covering the Owybee desert country in the extreme southwestern part of the State, in Owyhee County. Details concerning this are giren elsewhere in this bulletin.

The present distribution of antelope in the State is approximately as follows (fig. 6) :

1. A band ranges in Antelope Valley and the Pahsimeroi Mountains in Custer County. Forest Supervisor Olsen states that they inhabit the low open ridges lying at the base of the mountains generally, but occasionally a buck 
is seen in the higher elevations, even up to 8,000 feet. Mr. Olsen states that at one time he counted 104 antelope in this band.

2. Forest Supervisor Olsen states that three years ago a band of 12 adult antelope made the Sulphur Creek ranger station in Pahsimeroi Valley, Lemhi County, their headquarters. They became very fond of alfalfa, which grows plentifully there, and have remained there ever since, except that they sometimes go back into the hills a couple of miles or so during the winter season. They have been carefully protected by the forest rangers and have increased until the band now numbers 62 .

Forest Examiner S. B. Locke writes that at this time antelope in the Pahsimeroi Valley have become a nuisance at several ranches. At the ranch just about the ranger station 20 to 40 antelope enter the fields' during the summer and consume approximately one crop of alfalfa. While the hay is tall they do not cause much damage but feed on it intensively soon after it has been cut. Some of the ranchers keep them away from their fields by the use of dogs and shotguns. Any increase in the numbers here would intensify the losses of the farmers.

3. A band of $9^{\prime}$ is located near Goldburg, in Custer County.

4. A band of 25 is reported in Lemhi Valley, in southern Lemhi County. 5. About 25 live on Medicine Lodge Creek, in Clark County.

6. About 60 range on Birch Creek, in western Clark County and adjacent parts of Jefferson and Butte Counties.

7. About 75 are reported as ranging in Little Lost River Valley, in Butte and Custer Counties. Antelope from this area are said to range sometimes far out on the Snake River desert.

8. In July, 1924, a band of 4 was seen on the Snake River desert at Arco, in

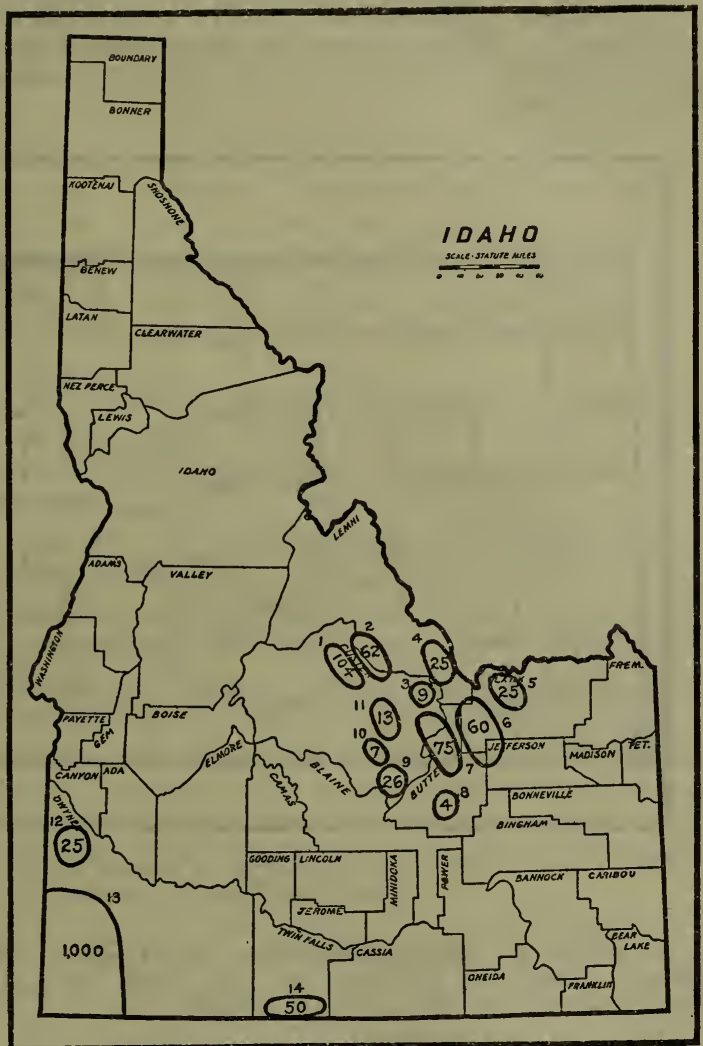

FrG. 6.-Distribution of antelope in Idaho, estimated at 1,485 , in 14 areas

Butte County.

9. A band of 26 was counted in 1923 in the Copper Basin, near Mackay, in southern Custer County.

10. A band of 7 exists near Chilly, on Big Lost River, in Custer County.

11. About 13 are reported to range about Horse Heaven Pass, at the head of Pahsimeroi Valley, in Custer County. A long-time resident of that section states that a few years ago this herd contained about 100 animals.

12. A band of 25 is reported as ranging on Succor Creek, in Owyhee County.

13. Southwestern Owyhee County is the most important area in Idaho for antelope. Reports state that two separate bands occur, one ranging from the Juniper Mountains in Owyhee County to the Nevada line, and the other occupying the country from the crest of the same mountains westward to the confluence of the Owyhee River and Soldier Creek in Oregon. L. J. Goldman, in charge of the predatory-animal work of the Biological Survey in Idaho, wrote that he had reports from authentic sources of from 600 to 1,000 occupy- 
ing the extreme southwestern corner of Owyhee County. They range from the Duck Valley Indian Reservation west to the Oregon line and probably into Jordan Valley, Oreg.. and from the Nevada State line to a point about 30 miles north. Stragglers and small bands undoubtedly stray beyond these limits. They also cross southward into Nerada. Their main summer range is about the forks of the Owyhee River and the Juniper Basin. E. Grandjean, of the Forest' Service, wrote that this band occupies the high plateau drained by the Owyhee River at altitudes varying from 4,500 to 6,000 feet. This area is fairly well watered and overgrown with grasses and sagebrush. In the middle of it are located the low, hilly Juniper Mountains, which are very rocky and cover an area approximately 10 miles wide by 20 miles long. This main plateau, except the wooded part, is used by antelope as spring, fall, and winter range. The animals usually appear there early in April and remain until early in winter, when the snow compels them to leave for their winter range, generally believed to be the low desert plateau lying south of the main Owyhee River.

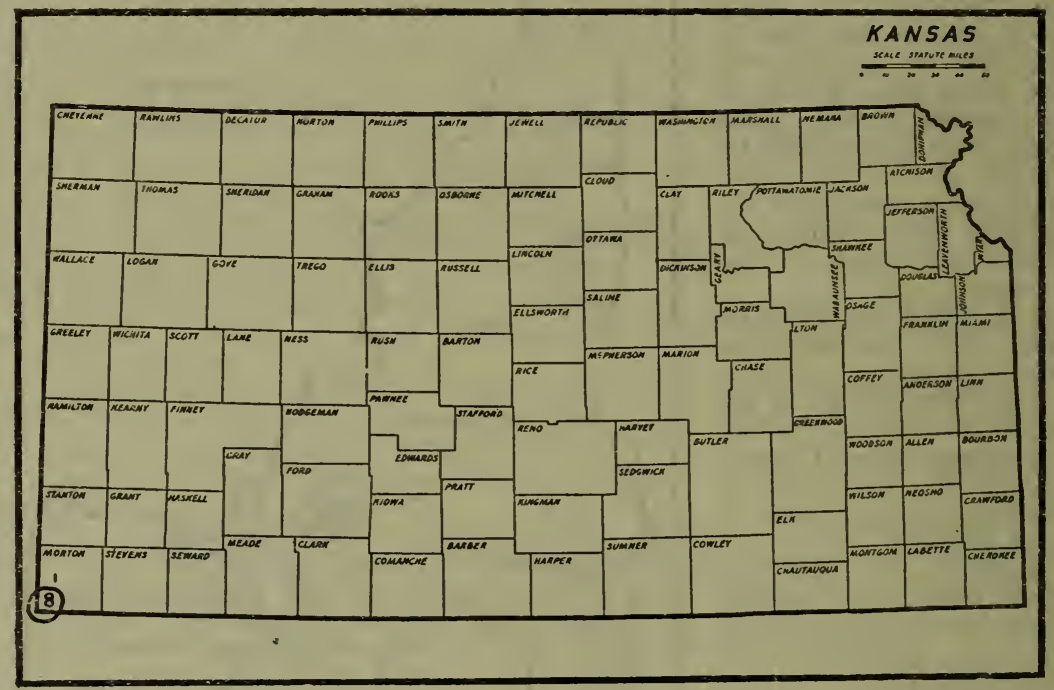

FIG. 7.-The only band of antelope in Kansas occurs in the extreme southwestern corner; estimated to contain 8 animals

14. Scattered bands numbering about 50 are reported to live on Browns Bench, along the Nevada line, in Twin Falls County. These undoubtedly range back and forth across the State line.

\section{KANSAS}

The only antelope definitely reported as existing in Kansas in 1923 was a band estimated to contain about 8 in the extreme southrestern part of the State, in Morton County. According to State Game Warden J. B. Doze they are reported to be more often in Oklahoma than in Kansas, passing back and forth across the line (fig. $\tau$ ).

At one time Kansas was inhabited by myriads of pronghorns, and for years, i after the construction of the transcontinental railroads they were a familiar sight to passengers on the trains. In 1923, however, they had become almost exterminated throughout the State.

In a letter dated July 2, 1924, Hal G. Evarts, of Hutchinson, wrote that he had recently received reliable information that in 1916 a herd of 62 pronghorns was ranging about 25 miles northwest of Cimarron, in the Pawnee Creek 
breaks. In 1918 he saw seven, which wintered within a mile of the town of Cimarrou. In 1921 a band of 16 spent the summer and winter about 15 miles soutl and west of Garden City. He has not seen them since that time, but is of the opinion that they may still be ranging in the sandhills of that vicinity.

\section{MONTANA}

In the early days the great plains of Montana contained countless thousands of antelope. The present census records surviving herds in 44 districts, mainly in the eastern and central parts of the State, with a total of approximately 3,000 animals. As in many other States, the antelope situation here is precarious and needs prompt attention if the herds are to be perpetuated.

The information given below is mainly the result of inquiries made by Thomas N. Marlowe, chairman of the State fish and game commission; C. A. Jakways, State game warden; by employees of the Forest Service; and especially by O. E. Stephl, R. E. Bateman, and other employees of the Biological Survey. It should be noted that several antelope herds drift back and forth between northern Montana and Canada, particularly from northern Valley and Hill Counties. In severe winters, antelope frequently drift down the Yellowstone Valley into the State from the Yellowstone National Park, Wyo.

Some ranchmen complain of injury to crops by antelope, one complaint relating to damage to alfalfa in Powder River County. Abandonment of ranches by a large number of dry-land farmers has restored more favorable conditions for antelope over considerable areas. Nany new settlers are interested in protecting the antelope, but from curiosity frequently kill a single animal to get an opportunity to taste its flesh. A considerable number of the older ranch owners who were in the State during the days when the antelope was one of the common game animals, are now taking an active interest trying to prevent the extermination of the species. In some cases they afford antelope the same protection against hunting on their ranges that they give their cattle. The antelope have learned these sanctuaries, and when shot at elsewhere immediately run to them for safety. Local sportsmen's associations are in position to be very helpful in developing antelope conservation in the State.

Thomas N. Marlowe, chairman of the State Fish and Game Commission, wrote as follows:

"The matter of further protection and propagation of the antelope is, to my mind, a very difficult one. In spite of what we have tried to do in this State, they seem to be, as stated in your letter, on the decrease and practically threatened with extinction. The only possible solution of the matter appears to be the creation of an antelope preserve somewhere in eastern Montana. This should be as thoroughly fenced as the buffalo range near here and the predatory animals destroyed.

"I believe also that a new herd should be started on the buffalo range. [It will be noted below that in September, 1924, a small herd was reestablished on the buffalo range by the Biological Survey.] I believe something can be accomplished along these lines, and if a reserve is created in eastern Montana possibly our department might be able to do something toward financing it, if not too expensive. I am with you in the hope that some solution can be found at the antelope conference to help remedy the situation.

"I am satisfied after having been a member of the State fish and game commission for more than five years that the greatest problem confronting us in this State in the protection of game is the control of predatory animals. If we could exterminate them there would be plenty of game in the State for all 
demands, as there is no doubt that predatory animals destroy more than all the hunters put together. Two years ago we framed a law setting aside 25 cents from eacli hunting and fishing license to cooperate with the Biological Survey in the destruction of predatory animals in connection with the State Livestock Association, but I am frank to say that the amount we are expending in this respect scarcely more than kills off the increase."

The antelope reported from Montana are distributed approximately as follows (fig. 8) :

1. A band of eight is reported in the vicinity of the Sweet Grass Hills, in Liberty County. Antelope are reported to have decreased in this district.

2. Another band of eight ranges along the Marias River, in Liberty County. It is reported that a few years ago several small herds were ranging 20 to 30 miles south of Chester, on the main line of the Great Northern Railroad, in Liberty County, but since then information has been conflicting, and nothing definite has been learned to indicate whether they are still there.

3. A band of $\mathbf{1 5}$ antelope south of Galata is said to contain the only antelope remaining in Toole County.

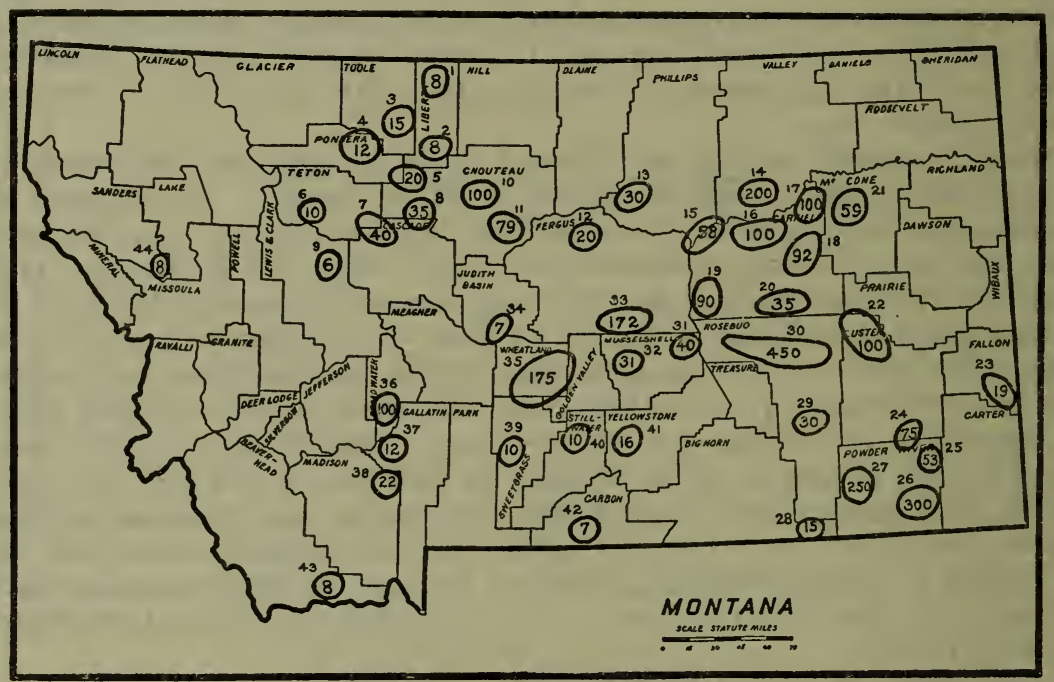

Fig. 8.-Distribution of antelope in Montana; estimated at 3,027, in 44 areas

4. About 12 antelope are still ranging on the Marias River and its tributaries, in Pondera County. Two years ago a band of about 12 ranged on the Marias River 30 miles northeast of Conrad, but people familiar with the district state that they have now disappeared. It is reported that bootleggers in high-powered automobiles passing through this district to Great Falls make a practice of pursuing and killing antelope on the open plains. The residents resent this killing but have been powerless to prevent it. It is reported also that the Conrad and Brady rod-and-gun clubs are interested in the preservation of antelope and will assist in their protection in any way that is practicable.

5. About 20 antelope are reported to range on the Teton River, in Pondera and Chouteau Counties, about 20 miles east of Brady.

6. A band of about 10 antelope is reported about 12 miles southwest of Chouteau on the north side of the Sun River, in 'Teton County. This band has decreased during the past few jears.

7. About 40 antelope are reported to range between Chouteau, Teton County, and Great Falls, in Cascade County.

8. Two bands, numbering about 35 , range north of Great Falls, in Cascade and Chouteau Counties.

9. A band of about six is reported to be ranging in the Dry Creek country, about 10 miles southeast of Augusta, in Lewis and Clark County. 
10. About 100 are reported north of Fort Benton, in Chouteau County.

11. A band of 19 was reported on February 9, 1924, to range immediately west and north of the town of Montague, Chouteau County, sometimes within half a mile. A few years ago this band was double its present size. Another band of about 60 , near the town of Square Butte, is reported to have increased about 10 per cent in the past two years.

12. Three small bands, aggregating about 20 , are located near Winifred, in northern Fergus County. One is 10 miles northeast of the town, another 18 miles, and the third is ranging near Armells Creek. The total number of antelope here is slowly decreasing.

13. A band of 30 was reported in 1922 south of the Little Rockies, in southwestern Phillips County.

14. On January 2, 1924, several bands, totaling about 200 antelope, were reported on the range from 20 to 30 miles southwest of Glasgow, in Valley County. A few range around the head of Duck Creek, Brazil, and Dry Runs. The larger bands occupy the country that divides the heads of Little, Beaver, and Lone Tree Creeks and on down the east slope to Willow Creek. The antelope here are reported to be decreasing rapidly and likely to be exterminated unless better protection can be given them. It is reported that antelope occasionally cross into the northern part of Valley County from Canada.

15. A band of about 50 ranges in the Missouri breaks in northwestern Garfield County, and a smaller band of 8 in the adjacent southeastern part of Phillips County between the Little Larb Hills and the Missouri River.

16. About 100 are reported on the Snow Creek Game Preserve in Garfield County.

17. In Garfield County a band of 70 is reported along the Missouri River in Townships 23 and 24, and a band of 30 north and east of Haxby.

18. There are several bands in eastern Garfield County, aggregating about 92 animals, of which 68 occur along Woody Creek, in Townships 40, 41, and 42, and adjacent areas, and about 24 along Big Dry Creek east of Jordan. Several years ago these and other bands in this county were decreasing, but since many dry farmers have left, they are beginning to increase.

19. A band of 60 ranges along Lodgepole Creek from Dilo to the Musselshell River in Garfield County, and another band of 30 occurs farther down in the southwestern corner of the same county.

20. A band of about 20 is located near Colagen, and another band of 15 ranges in Townships 13 and 14 , both in southern Garfield County.

21. In February, 1924, 38 antelope were reported as ranging on the Timber Creek Divide, a small herd of 7 west of Weldon, another numbering 7 near McDonald Butte, 6 on Jawbone Coulee, and a single buck on the Big Dry, totaling 59 animals in McCone County.

22. Frank Hamlick, a deputy State game warden at Kinsey, Custer County, wrote on January 21,1924 , that 49 antelope were living in his pasture, and that various other bands were located within 15 miles, which in the aggregate amount to about 100 animals. He is doing all he can to protect them, but they are being killed by hunters.

23. Three small bands, aggregating about 19 animals, occur in southeastern Fallon County, where they are reported to be decreasing.

24. A band of 75 is reported to range on Mizpah Creek, in southern Custer and northern Powder River Counties.

25. C. A. Hatterschied wrote in February, 1924, that in the preceding fall he counted a herd of 53 antelope on Timber Creek, in Powder River County.

26. In January, 1924, P. E. Fannigan, of Graham, wrote that several herds of antelope occur in the country lying east of the Big Powder River, in southern Powder River County. He considers that they aggregate more than 300 animals. One neighbor counted 270 antelope in his pasture on one occasion last year. They do not appear to be increasing, but some of the farmers complain that they are eating their alfalfa. From the reports, it is probable that there are other antelope in this section of the State, but details are lacking. C. A. Hatterschied reports seeing a herd of 47 on Horse Creek in the fall of 1923.

27. Bands totaling 250 range on the Custer National Forest southeast of Ashland, in Powder River County. B. W. Hogan, of Ashland, wrote that when he went there in 1910 there were only 3 antelope in the entire Custer National Forest. These were well protected by ranchmen and have increased to the present herd. They are often seen in bands of from a dozen to more than 
100. The Custer National Forest appears to be ideally adapted to their needs.

Powder River County appears to have the largest number of antelope in any area of that size in the State. R. F. Tarbell stated that the largest band on a ranch in the southern part of the county numbered 57. This increased somewhat during 1923 , but, as a whole, the antelope hare barely held their own during the past 10 years. At the present time they are not being molested and undoubtedly are increasing.

28. A band of about 15 is reported in the extreme southeastern part of Big Horn County, on the Tongue River, near Decker. It is being protected and is slowly increasing.

29. A band of about 30 , which is reported to be increasing in numbers, is ranging south of the Yellowstone on Otter and Bearer Creeks in southern Rosebud County.

30. North of the Yellowstone River, along Stella, Hay, Wolf, and Cottonwood Creeks, and also between Forsyth and Melstone, are a number of bands of antelope varying in size up to nearly 200 animals, which aggregate about 450. They are said to be holding their own or increasing in numbers.

31. In a district about Melstone, in Musselshell County, three small bands, totaling about 40 animals, are said to be decreasing.

32. A band of 31 is reported on the Gumbo Flats north of Roundup in Musselshell County.

33. A band of 172 was counted along Elk River on the Jack Rowley Ranch, about 50 miles southeast of Lewistown, in Fergus County. Mr. Rowley states that for the past 10 years from 100 to 125 antelope have been ranging on the ranch about 50 miles southeast of that town. During the fall of 1923 he counted 172 in one band, which apparently corered the entire number. He states that they ordinarily run in three or four bands, but occasionally unite. They have many young; but, although efforts have been made by the owners of the ranch to protect them, they continually stray off and are shot by hunters. When fired at, those not hit usually seek safety in the meadows on the ranch where they seem to appreciate the fact that they are protected. Mr. Rowley belieres that since so many dry farmers hare left that section of the State, conditions are more favorable for the antelope, which are likely to increase in numbers.

34. A band of 7 is located in the foothills of the Big Snowy Mountains south of Moore, in Judith Basin County.

35. About 175 antelope are located mainly in Wheatland County. Of these, two bands of about 20 each range near Rothiemay in western Golden Valley Countr, about 80 on the Winnecock Sheep Ranch, 5 to 10 miles southwest of Shawmut, and a few small bands numbering about 30 northwest of Twodot, the last-named bands being all in Wheatland County, also 25 near Porcupine Butte, northern Sweetgrass County. It is reported that the antelope in this area have been decreasing rapidly since 1908 through hunting from automobiles.

36. About 100 antelope ranged near Radersburg, Broadwater County, in 1923. It is stated that some of these can be seen from the main road at almost any time.

37. A band of 12 was reported near Three Forks, in Gallatin County, in 1912 , but no information has been receired concerning them since.

38. About 22 antelope are reported to live on the old Green Ranch immediately west of Madison River near the mouth of Cherry Creek, in Madison County. This band has decreased during the past 15 years.

39. A band of about 10 is located on the Little Timber and Duck Creek Ranges in Sweetgrass County.

40. A band of 10 ranges near Gibson, in the Big Coulee Country, in northern Stillwater County.

41. Several bands, numbering at least 16, range about 20 miles northwest of Billings, in Yellowstone County.

42. A band of 7 is reported on Lone Creek, near Red Lodge, Carbon County.

43. The only antelope reported in Bearerhead County is a band of 8 ranging on Red Rock and Black Tail Creeks.

44. Eight antelope were placed on the National Bison Range in September, 1924, by the Biological Survey, in cooperation with Doctor Brownell, of San Francisco, and Doctor Hornaday, of the Permanent Wild Life Protection Fund. These antelope were from the Washoe Antelope Reservation in northwestern Nerada, where they were caught as newly born fawns in the spring 
of 1924. The antelope placed on this range by the Boone and Crockett Club in 1911 increased to 64 , but all are believed to have been killed by predatory animals in 1922.

\section{NEBRASKA}

Of the countless thousands of antelope which once roamed the plains of Nebraska but 10 small bands remain, containing a total of about 187 animals. $\Lambda \mathrm{s}$ in Kansas and some other western States, for many years following the completion of the first transcontinental railroad, passengers through Nebraska had the pleasure of observing many antelope from the train windows. With the increasing occupation of the State by farmers and stockgrowers the pronghorn has been reduced to the present insignificant numbers.

Only a single attempt appears to have been made to establish and maintain under confinement a herd of antelope in this State. This was done in September, 1924, when the Biological Survey, in cooperation with Doctor Brownell and Doctor Hornaday, as detailed elsewhere, placed 10 young antelope from northern Nevada on the Niobrara Reservation, a Federal game refuge near Valent:ne. Conditions there appear to be well suited to antelope,

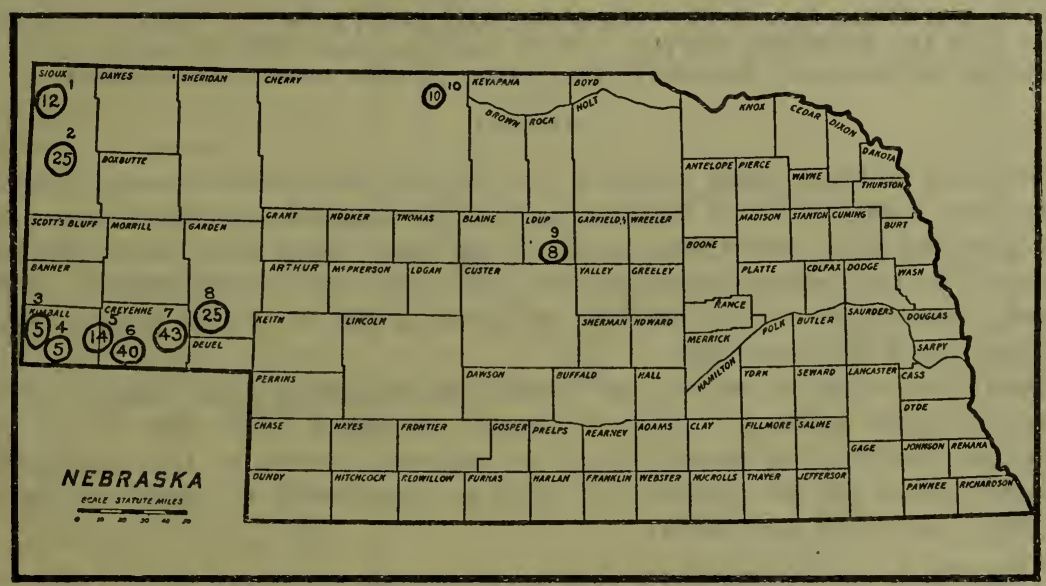

Fig. 9.-Distribution of antelope in Nebraska, estimated at 187, in 10 areas

and it may be possible to build up an interesting herd. In order to insure the perpetuation of these beautiful animals in Nebraska, another herd might well be established elsewhere in the State.

The occupation of Nebraska for farming purposes is so complete that there is little hope of a herd being maintained there except under fence. Safe free range for antelope in this State is a thing of the past.

In a letter dated March 12, 1924, George Bird Grinnell wrote that three or four years ago a band of about 40 antelope was located somewhere along the North Platte north of Bridgeport, Morrill County. According to the latest accounts he had they were rapidly decreasing.

Supervisor Jay Higgins, of the Nebraska National Forest, supplied information in the spring of 1922 that there were bands of antelope in Scotts Bluff, Banner, and Kimball Counties, and added: "We secured three conrictions for killing antelope in Scotts Bluff and Kimball Counties."

The antelope bands existing in Nebraska in 1922 and 1923 were distributed as follows (fig. 9) :

1. A band of about 12 reported in 1922 as near the 33 Ranch, in Sioux County, near the Wyoming line. 
2. A band of about 25 ranged near Agate, in Sioux County, in 1922. These have existed in about the same numbers for the past 10 years.

3. A band of about 5 was reported in 1922 about 10 miles west of Bushnell, in Kimball County.

4. A second band of 5 was reported in 1922 near the State line, south of Kimball, in Kimball County.

5. A band of 14 was reported in 1922 between Dix and Potter, on the border between Kimball and Cheyenne Counties. Their numbers for some years have remained about stationary.

6. A band of about 40 was reported in 1922 as ranging about 18 miles south of Sidney, in Cheyenne County. For some time this band has about held its own.

7. A band of 43 was reported in the spring of 1922 as grazing in fields near Sunol, in eastern Cheyenne County. The farmers complained of this invasion of their wheat fields by antelope and requested information of the Forest Service as to what might be done to control them.

8. A band of 25 was reported in 1922 about 12 miles south of Lisco, Garden County. This herd had about held its own for some time.

9. A band of 8 was reported in March, 1924, about 15 miles north of Sargent, in Loup County.

10. Ten young antelope, 6 females and 4 males, were placed on the Niobrara Game Reservation in September, 1924, by Doctor Brownell, of San Francisco, and Doctor Hornaday, of the Permanent Wild Life Protection Fund, in cooperation with the Biological Survey. These antelope were part of the fawns captured in northwestern Nevada in the spring of 1924, as already detailed.

\section{NEVADA}

Formerly antelope were plentiful over all the Great Plains and deserts in this State. They are now limited to about 11 comparatively small areas. In the northern and northwestern parts of the State occur great areas sparsely occupied by man, where conditions are still favorable to these animals. As a result, some of the largest herds to be found in the West still survive there, aggregating more than 4,200 .

Legal protection for antelope in Nevada has undergone some changes in the past few years which it will be of interest to record. The close season for antelope was lifted in Nevada by an act approved March 23, 1921 (amending chapter 234 of the act of March 27, 1917, as amended by act approved March 4, 1921), providing as follows:

"SEC. 42. It shall be unlawful to kill, catch, trap, wound, or pursue with the intent to catch, capture, injure, or destroy any deer or antelope at any time during the year other than during such 30-day period to be known as the open season between September 15 and December 15 of each year as may hereinafter be designated for the respective counties by the boards of county commissioners thereof under the provisions of section 50 of this act; provided that there shall never be any open season on deer without horns and that during such open season of each year it shall be unlawful to kill, catch, trap, wound, or pursue with the intent to catch, trap, injure, or destroy more than one deer with horns and one antelope with horns; and provided further that in all counties in which no designation to the contrary shall have been made by the county commissioners prior to the 1st day of August of any year, the open season for deer with horns or antelope shall be from October 14 to November 12 , both dates inclusive.".

An act approved March 21, 1923, restored antelope to the protected list until 1930 , in the following terms:

"SEc. 9. It shall be unlawful at all times to take any mountain sheep, goats, elk, or antelope until January 1, 1930."

After the opening of the season on antelope in Nevada in 1921 there was a feeling among some of the county commissioners in the northern part of the State that an open season was called for. E. R. Sans, predatory-animal inspector of the Biological Survey, working with the Washoe County Game 
Protective Association, pointed out to the boards of supervisors in Humboldt and Elko Counties the undesirability of an open season on antelope, and as a result the season was closed by them for two years. In Washoe County the board of supervisors felt the technical requirements of the law called for an open season, but were so well convinced of the undesirability of permitting antelope to be killed in any numbers that they limited the open season to onehalf hour, extending from 7.30 to 8 a. m., November 10 . It is obvious that under such conditions no antelope were legally killed in Nevada that season.

The information concerning the distribution and numbers of antelope in Nevada has been furnished mainly by Mr. Sans and by Supervisor Alexander McQueen, of the Humboldt National Forest. Mr. Sans has been extraordinarily successful in promoting antelope protection in Nerada. His friendly cooperation with the State authorities and the active part he took at the request of the governor in helping to locate and outline the antelope refuges in' the northern and northwestern parts of the State hare been a major serrice to the conservation of these animals:

The distribution of antelope in Nevada is approximately as follows (fig. 10) :

1. This area is the washoe County State Game Refuge (Pl. V, fig. $2)$. The number of antelope within its limits is estimated by resident stockmen at from 2,000 to 2,500. E, R. Sans wrote:

"Predatory Animal Hunter R. W. Young, stationed at the Thomas Dufurrena ranch in the Thousand Creek district of Humboldt County, re-

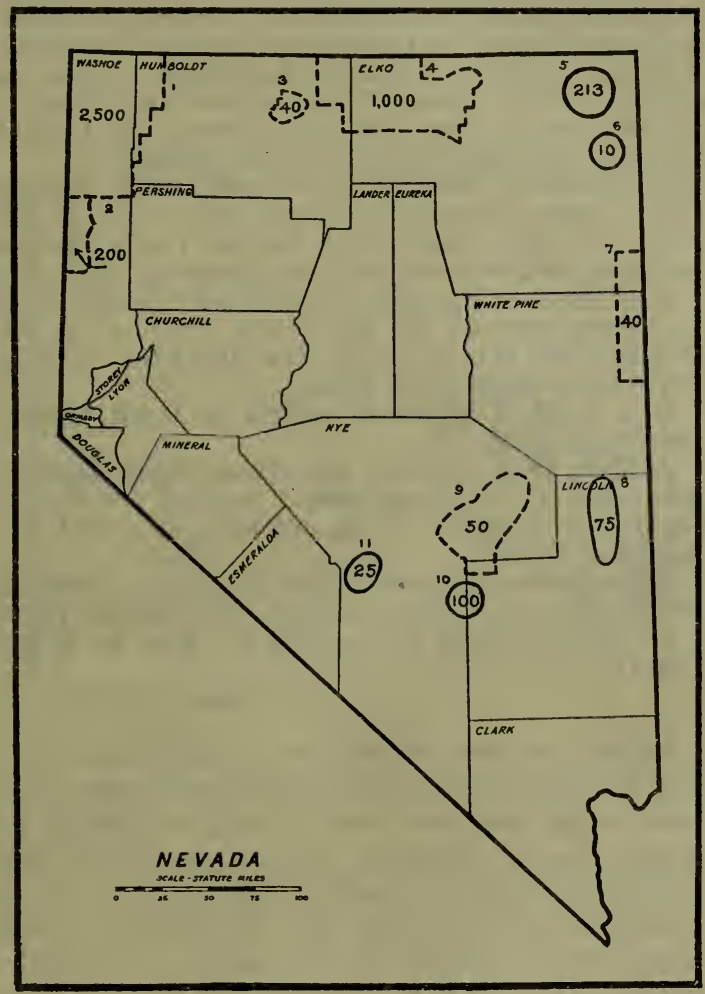

FIG. 10.-Distribution of antelope in Nevada, estimated at 4,253 , in 11 areas. Game refugees indicated by broken lines ported on January 17, 1924, that he saw not less than 1,000 antelope in the course of a day's travel in that neighborhood, and from reliable reports we gather that this is the wintering ground for these animals.

“T. B. Harriman, one of our predatory-animal trappers working in northern Washoe County, reported December 19, 1923, a band of from 600 to 700 antelope migrating to their winter range in the High Kock Canyon. This is the largest band we have had any notice of wintering in High Rock Canyon. There have always been a few coming into this sheltered district to winter, but this winter an unusually large number is there."

Further interesting information concerning the antelope on this game refuge is contained in statements received from Mr. Sans, which are set forth in the account of his capture of the young antelope for restocking purposes during the present season. 
2. This area covers the Smoke Creek antelope refuge of Washoe County, south of the main Washoe County refuge. Mr. Sans wrote:

"From reliable information I learn there are about 1,000 antelope ranging from Willow Creek, northeast of Susanville, in California, to Smoke Creek, in Nevada. The larger part of these appear to range in Secret Valley and the tablelands in Nevada to the railroad to Amadee and Ravendale, Calif., on the north."

These herds include those recorded for Lassen County, Calif., and those which remain permanently in Nevada. On account of the uncertainty as to the exact number in Nevada, they have been placed at 200 animals, although at present they must exceed 1,000, owing to the California herds having temporarily entered this area, as set forth in the account of the California antelope.

3. About 40 antelope are reported to range on the Santa Rosa State Recreation Ground and Game Refuge in eastern Humboldt County.

4. Various bands, aggregating about 1,000 antelope, are reported to occupy this area, which includes the Humboldt State Recreation Ground and Game Refuge, in Elko and Humboldt Counties. This area is the southern extension of the Owyhee Desert from across the boundary in Idaho. Some of the antelope range back and forth across the Idaho line. These bands are said to be holding their own, if not increasing.

5 . This area contains bands numbering, respectively, $29,43,71$, and 70 , by actual counts, ranging on Nine Mile Flat, 16 miles east of Contact and between the Bad Lands and Loomis Creek, in Humboldt County. These 213 are said to have increased from 20 during the last seren years.

6. A band of about 10 ranges near Cobre, in Elko County.

7. This area covers the White Pine State Recreation Ground and Game Refuge (No. 12), in White Pine and Elko Counties. A band of 40 antelope is reported to be ranging there.

8. A band of about 75 ranges in Duck Valley, from Geyser to Pioche, in Lincoln County.

9. This area includes the Grant State Recreation Ground and Game Refuge (No. 4) in Nye County. Several small bands of antelope, estimated to aggregate from 35 to 65 animals, are said to range within this area in Railroad Valley.

10. A band estimated at 100 was seen during the spring of 1923 near White Blotch, Lincoln County, and in the adjacent parts of Nye County.

11. A band of 25 is reported to range in Wild Hor'se Valley, southern Nye County.

\section{NEW MEXICO}

Antelope in New Mexico are decreasing, but up to the fall of 1923 they were still found in 31 areas, with an estimated total of 1,682 survivors from the vast herds which once occupied this region. Details concerning their numbers and distribution in this State set forth below are largely the result of careful investigations made to March 1,1924 , by $\mathrm{L}$. C. Petree, chief deputy in the State department of game and fish. In addition information has been supplied by employees of the Forest Service and of the Biological Survey and by individuals in the State. District Forester Frank C. W. Pooler, of Albuquerque, submits some interesting ideas on antelope conservation, as follows:

"I imagine everybody agrees that the nucleus of any scheme should include several Federal game preserves covering herds like the one proposed in adjacent parts of Oregon and Nevada. Such preserves, however, can not go further than to serve as a kind of rock-bottom insurance against total disappearance. The big problem is to secure an effective care of the scattered herds running on all kinds of land under all kinds of jurisdictions.

"Could not the Biological Survey be designated by the proposed convention as the central agency to perform the following steps with respect to each herd for which there appears to be a reasonable chance of perpetuation:

"(1) Determine the number, range, and condition of the herd.

"(2) Assign custodianship of the herd to some one party. This might be the Forest Service, the State game department, some stockman, or possibly some game protective association. 
“(3) Confer with such agency as to the step necessary to insure perpetuation; such steps might include the establishment of State game refuges, the offering of rewards against killing, pledges on the part of the stockmen to exercise rigid jurisdiction over their employees, pledges of winter feeding, or arrangements for predatory-animal control.

"(4) Ask for the necessary cooperation from the necessary parties to assure the execution of the measures decided on under the preceding paragraph (3).

"(5) Require from the custodian at least an annual report on the condition and needs of the herd.

"Let me offer one example of how the foregoing scheme would work. On Diamond Creek in the Gila Forest is a herd of about 25 animals, which have lodged there in timbered country since a blizzard drove them out of the San Augustine Plains about five years ago. This herd has plenty of feed and water, very fair protection against predatory animals, and no greát likelihood of illegal killing except during the deer season, when they are occasionally mistaken for deer by hunters. A special warning to all hunters in that locality, supplemented by a little extra patrol during the 10 days of the hunting season, would, I think, cause them to start increasing. The Forest Service would, I think, assume the special custodianship of this herd and would have the cooperation of the stockmen. If authorized by the forester it might be that we could eren require certain special precautions by the two or three stockmen affected against any of their employees damaging this herd.

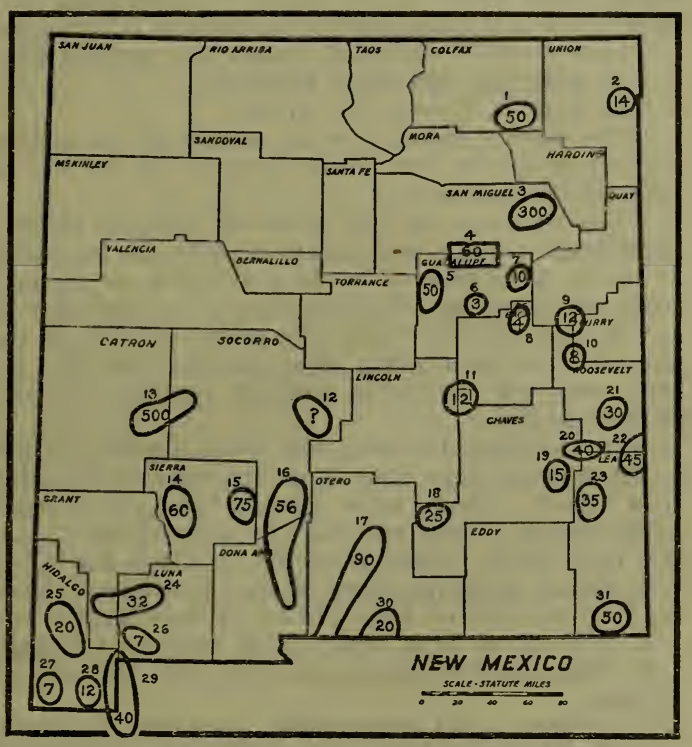

FIG. 11.-Distribution of antelope in New Mexico, estimated at 1,682, in 31 areas

Should predatory animals get worse, we would doubtless have your cooperation whenever we reported the situation. The main thing would be that somebody would assume responsibility for doing all reasonable and practicable things for the herd:"

Mr. Pooler's contribution contains some very practical suggestions, some of which might be utilized as the program for antelope conservation develops.

Antelope for many years have been protected on the well-known Bell ranch, where there has been a standing offer of $\$ 50$ reward for the arrest of anyone found hunting on these lands; but under this protection they have not increased so rapidly as might be expected, probably owing to the depredations of predatory animals and eagles.

The bands of antelope in New Mexico are located as follows (fig. 11) :

1. About 50 antelope range in southeastern Colfax County.

2. A band of 14 was reported in February, 1924, in the Eklund pasture, 15 iniles northwest of Clayton, Union County. 
3. About 300 antelope are estimated to occupy the area of the original Bell ranch, eastern San Miguel County, now partly owned by the Tom B. Owens Co. and by Dan C. Trigg, jr. This is the largest number of antelope in any restricted district in the State. The first-hand information here presented concerning these animals shows the need of a careful survey of the situation in this district as a basis for further conservation measures. The friendly attitude of protection toward the antelope by the owners of the ranges indicates possibilities of building up here considerably larger herds than now exist. Owing to the large size of this area there has been some difficulty in getting definite information concerning the present situation. C. M. O'Donel, manager of the Bell ranch, under date of July 20, 1923, supplied the following:

"The sum of the reports from employees in various parts of the range gives the number of antelope within the present boundaries of the ranch as 217 . Naturally this can not be an accurate count, though the habit of antelope to 'locate' in bunches makes it more accurate than would probably be the case with other varieties of game. ***

"I believe that antelope are increasing on this range only rery slowly, if at all. My opinion is that their natural enemies, of which perhaps the eagle is the worst, keep down the increase by destroying the young. I believe we had as many, if not more, antelope here when I first came to the ranch 25 years ago."

Inquiry was instituted among the purchasers of parts of the original Bell ranch, with the following results:

The Tom B. Owens Co. wrote:

"We hardly know how to arrive at an estimate of the number of antelope on our property, but think around 100 to 150 old ones, with possibly a fawn crop of 50 this year.

"The antelope on our place as well as on the Bell ranch are found on the level open valleys and rarely go into the mountains for any reason. We have, it seems, a surplus of bucks and often see them off by themselves, they having been whipped out of the herds by the younger and stouter bucks.

"We do not know of any other section of the country where the antelope are as often seen as on these ranches, and we never take any kind of drive or ride over our pastures without seeing several bunches of various numbers, from 2 to $20 . "$

Dan C. Trigg, jr., who now owns a part of the original Bell ranch, wrote:

"A few antelope stay in my pasture all the time. I have seen as many as 26 in a bunch. There have always been two separate bands in different portions of my ranch. They are more or less migratory and have a habit of crossing into the Bell ranch, which joins my holdings for several miles."

4. Bands totaling about 60 antelope are reported from the ranches of Senator $\Lambda$. A. Jones and of John Hicks, in San Miguel and Guadalupe Counties.

5 . A band of 50 is reported in western Guadalupe County.

6. Three antelope are on the Ed. Morrow ranch, in southern Guadalupe County.

7. A band of 10 is reported in eastern Guadalupe County.

8. Four antelope are reported on the Buckeye ranch, near Taft, in northern De Baca County.

9. A band of 12 is on the Charles Orr ranch, near the cornering parts of Roosevelt, Curry, and Quay Counties.

10. A band of 8 occurs on the C. S. Hart ranch, near the borders of Roosevelt and Curry Counties.

11. A band of 12 is near the bordering corners of Lincoln, De Baca, and Chaves Counties.

12. A band of antelope is reported as living in southeastern Socorro County, but the number is not given.

13. Herds aggregating 200 or more are reported as ranging on the Sall Augustine plains, in Catron and Socorro Counties. This number was verified by actual count reported by the Magdalena Game Protective Association, but those familiar with the situation believe that there are many more than that number in this district. G. W. Evans, of Beaverhead, states that 200 antelope, by actual count, live on his 50,000-acre ranch in the southwestern portion of San Augustine plains, in Catron County, within the general area reported by the Magdalena Game Protective Association. It is obvious that there are in this Great Plains region many more antelope than those here listed, possibly 500 in all. Formerly the San Augustine plains were a favorite resort for thousands of antelope.

14. A band of about 60 ranges in western Sierra County. 
15. Clyde L. Grow, reservoir superintendent of the Reclamation Service, wrote from Engle, N. Mex., on September 12, 1924, reporting between 50 and 75 antelope on the east side of the Elephant Butte Reservoir, in the Cristobal Mountains, in eastern Sierra County. He added that they were fed during the deep snow all the preceding winter by the Victoria Land \& Cattle Co. and are in good condition. They range to the vicinity of Engle, where they are sometimes seen by passengers on the Santa Fe Railroad trains. In 1883 the writer had the opportunity to observe personally a very considerable number of antelope ranging the plains about Engle, particularly to the east and nortl. The proprietor of the single hotel and general store there at that time kept a pack of greyhounds which he fed on antelope meat. His sole amusement in this isolated place was to drive out with a buckboard on the open plains, accompanied by his greyhounds, until he found a band of antelope, when the greyhounds were sent in pursuit while he followed until the dogs had pulled down and killed one or more of the animals, which he carried back for dog food.

16. A band of 56 antelope was reported to be ranging between White Sands and the Organ and San Andres Mountains, in Socorro and Dona Ana Counties.

17. In southwestern Otero County 90 antelope are reported by Oliver Lee, manager of the Sacramento Land \& Cattle Co., and others.

18. A band of 25 ranges about the headwaters of the Felix River, in southwestern Chaves County.

19. The "L. E." pastures in eastern Chaves County are occupied by a band of 15 .

20. H. E. Crosby, of Kenna, reports 40 antelope living in the pastures of the Crosby ranch in eastern Chaves County.

21. A band of 30 is reported ranging on the Littlefield ranch, on the Staked Plains, in central Roosevelt County.

22. In northeastern Lea and southeastern Roosevelt Counties 45 antelone are reported ranging on Bakers Flats and across into adjacent parts of Texas. A small band, the number not specified but reported to have been living in northern Lea County for several years, has raised no fawns, owing to the depredations of predatory animals. In the spring of 1923, following a cooperative campaign against these destructive pests by the Biological Survey and the State, a number of fawns survived and this herd may now increase.

23. A band of 35 antelope is reported in western Lea County.

24. There is a barid of 10 near Cow Springs, in southern grant County, and one of 22 on the Antelope Plains of western Luna County.

25. A band of 20 is reported as ranging in the San Luis Valley, in Hidalgo County.

26. A band of 7 is in southwestern Luna County.

27. A band of 7 is reported also in the Juniper pastures, Animas Valley, in Hidalgo County.

28. In 1922 a band of 12 was reported in Playas Valley, in Hidalgo County.

29. About 40 antelope range in extreme southeastern Hidalgo County, some of which cross into the adjacent part of northwestern Chihuahua.

30. Twenty antelope range from southern Otero County south into Texas.

31. About 50 antelope occur in San Simon Range, in southern Lea County.

\section{NORTH DAKOTA}

Antelope hare almost disappeared from North Dakota. The remaining herds now number only five and aggregate 225 animals. Their future appears to be extremely doubtful unless a game preserve can be established wherein they may be safeguarded. The information concerning antelope in North Dakota has been obtained by H. L. Rice, of the North Dakota State Game Commission, and R. Scott Zimmerman, in charge of rodent-control work in the State for the Biological Surrey.

The distribution of the herds is approximately as follows (fig. 12) :

1. In September, 1924, 60 antelope were reported as ranging from northwestern Dunn County into the adjacent part of McKenzie County.

2. A band of 9 was reported in September, 1924, in southwestern McKenzie County. 
3. About 75 are reported in adjacent parts of central Golden Valley and Billings Counties. This is the largest band reported in the State. William McCarthy, who owns 11,000 acres of rough, rolling land in the heart of the Bad Lands along the Missouri River, which affords a natural range for game, writes that when he came into possession of the range in 1910 there were about 15 antelope there. Much hunted, they sought and were given every protection in his pastures, where they found running springs and flowing wells with an abundance of grass, and as a result hare become very tame.

4. Bands numbering 55 were reported in September, 1924, in the Bad Lands of the Little Missouri River in Slope County.

5. In September, 1924, a band of 26 was reported from southwestern Bowman County.

\section{OKLAHOMA}

Of the vast number of antelope once roaming the prairies of Oklahoma only a single native band, containing 5 or 6 animals, was reported as surviving in 1923, and the small band on the Wichita National Game Preserve, in Comanche County. (See II. I.)

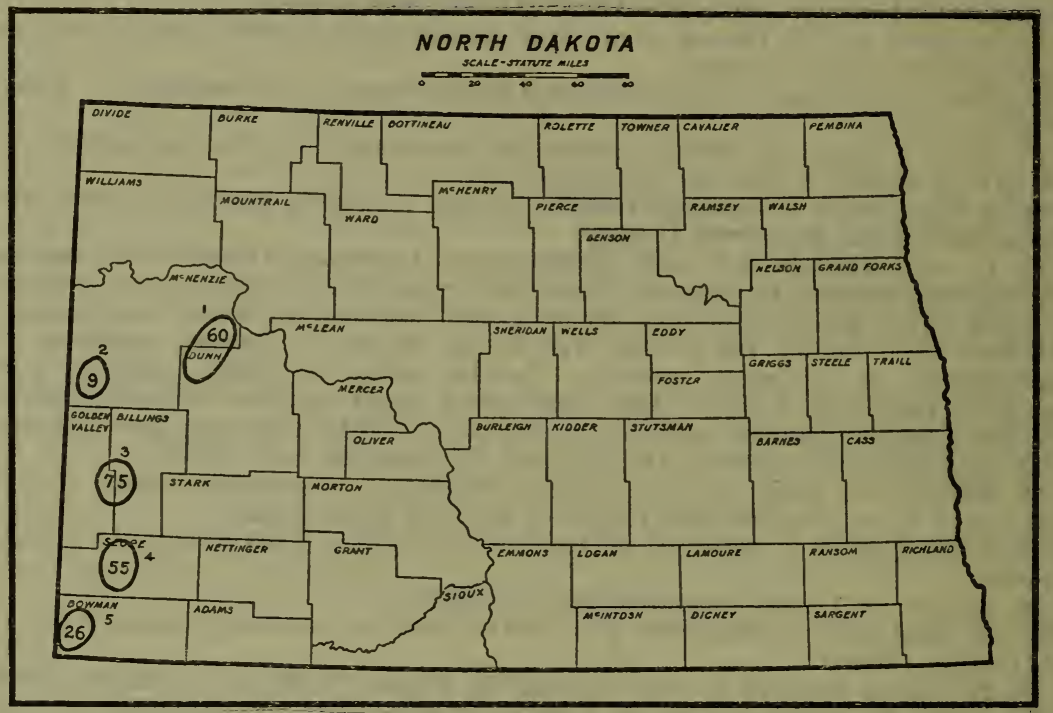

Frg. 12.-Distribution of antelope in North Dakota, estimated at 225 , in 5 areas

In December, 1910, and January, 1911, the Boone and Crockett Club transported 9 antelope from the Yellowstone National Park herd to the Wichita National Game Preserve. This experiment had an unfortunate ending, since all the animals died during the next few years. Another attempt was made in the fall of 1921 by the American Bison Society to established a herd on this preserve by placing there 10 animals which had been purchased at Brooks, Alberta. Six of these died shortly afterwards, and in the fall of 1922 the Bison Society placed 6 more there from the same source. Of these 5 died shortly afterwards, leaving during the winter of 1922-23, 5 survivors from the original transplantings of 16 . In the spring of 1923 the 3 females each gare birth to a pair of young, which were safely reared. This was duplicated in the spring of 1924 , bringing the number in the herd to 17 . The handicap which at first existed appears to have been overcome, and the outlook is farorable for the establishment there of a good herd. 
The following interesting quotation from a letter from District Forester Reed, United States Forest Service, dated June 20, 1923, gives an idea of the vicissitudes undergone by the antelope during the last two introductions:

"We have just received word from Mr. Rush that there is but one survivor of the six shipped to the Wichita last fall. This survivor is a buck. Two of the antelope died from the effects of ticks and two have disappeared. Mr. Rush surmises that the coyotes got in and killed them while they were in the little bull pasture. Later they were moved into the buffalo yard, and the ouly female left ran headlong into the gate and broke her neck. Of the antelope shipped two years ago, one 2-year old buck and three 2-year old does remain. This reduces the herd to 5 adult antelope.

"Mrr. Rush reports that the 3 does now have 2 fawns each. This brings the herd up to 11 head, and Mr. Rush says that he had excellent luck with them. It is to be hoped that the fawns born in captivity on the Wichita will survive the vicissitudes which decimated the original shipment made by the

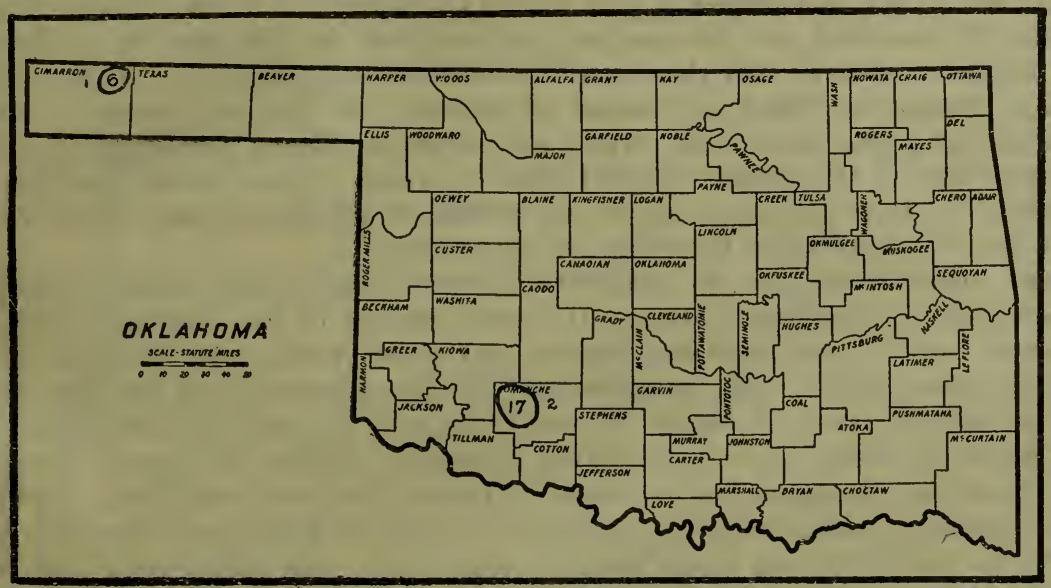

FIG. 13.-Distribution of antelope in Oklahoma, estimated at 23, in 2 areas

American Bison Society. Since we have 11 antelope on the Wichita, it does not seem necessary to seek further assistance from the American Bison Society at this time. We will, however, take the best care of the remaining antelope. We are satisfied that Mr. Rush has done his best, and it seems that we have a fighting chance to secure a herd of antelope on the Wichita."

The location of the two bands of antelope now in Oklahoma may be stated as follows (fig. 13) :

1. A single band of 5 or 6 animals is living in the Ford pastures in northeastern Cimarron County, where it is protected. A band of about 8 animals, reported to range in Morton County, southwestern Kansas, is said to spend part of its time across the line in Oklahoina, which would take it into Cimarron County. The relations between these two herds have not been ascertained. For convenience the 8 animals are credited to Kansas and make up the only known surviving anteiope in that State. Apparently the only survivors of these animals in both Oklahoma and Kansas are in the adjoining counties of the extreme western parts of these States.

2. During the summer of 1924 a herd of 17 antelope was on the Wichita National Game Preserve. This is an increase of 12 animals from the 5 survivors of 25 animals imported in previous years by the Boone and Crockett Club and the American Bison Society. 


\section{OREGON}

Southeastern Oregon forms part of a rough, rocky desert covering also northern Nevada and southwestern Idaho, on which natural conditions have been exceedingly farorable for antelope. This region constitutes one of the few areas in the United States where large herds of these animals numbering hundreds still continue to congregate during the winter season. Southeastern Oregon corers so large a territory and the herds in it are so widely scattered that it has not been practicable definitely to locate them and ascertain their numbers. For this reason an area has been marked on the accompanying map (fig. 14) corering the main antelope territory, within which it is estimated that the different herds contain an aggregate of not less than 2,000 animals. Most of the definite information concerning antelope in Oregon has been supplied by Stanley G. Jewett, of the Biological Survey, and W. L. Finley, of the National Association of Audubon Societies.

There is no question that antelope have increased in Oregon during the past few years, and although year by year a considerable number have been killed by poachers, yet this has not been sufficient to overcome the increase. It has been reported that the climatic conditions were especially favorable for them during the winter and spring of 1923-24, and that an unusually large number of young were born. Water and range conditions were worse in this district during the summer of 1924 than for years. Cattle owners moved all their stock from this range about the middle of August and as a result conditions were made more favorable for the antelope.

Old Fort Warner and the neighboring Desert Lake appear to be centers of abundance for antelope. Stanley G. Jewett, leader of the predatory animal control work of the Biological Survey in Oregon, writes that while he was there during August, 1924, antelope were in sight practically all the time, and he is confident that on August 16 and 17 he saw not less than 500 within a radius of 15 miles. In a letter dated September 2, 1924, Mr. Jewett stated:

"I am sorry to report that a number of fawns have been found dead. Jacobs reports about 20 dead within a radius of 15 miles from old Fort Warner. An old doe was sick near camp while I was there. She acted much like an alkalied cow. This condition has probably been brought about by the extreme drought and the fact that the does have not had enough nourishment properly to feed their young. Range conditions are so bad that the big cattle companies have taken all their cattle from that range."

Such adverse conditions must prevail not only orer eastern Oregon but into the adjacent parts of Nevada and Idaho. What the outcome will be as to the antelope in this great area is a serious question, since it is one of the greatest centers of surriving antelope in the entire West.

For a number of years various persons interested in the conservation of antelope have been advocating the establishment of a Federal antelope refuge in southeastern Oregon. Details concerning this project are set forth elsewhere in this bulletin.

The present distribution of antelope in Oregon is as follows (fig. 14) :

1. During July, 1924, a single antelope was seen at different times near Antone, in Wheeler County, which is considerably outside the general distribution area of antelope at the present time and may indicate a gradual extension of range into formerly occupied territory.

2. In July, 1924, an isolated herd of about 18 was observed on Twelve Mile Creek in the southeastern part of Crook County and the northwestern part of Harney County.

3. A herd of about 20 was ranging in July, 1924, on the northeastern side of Harney Valley from Saddle Butte north to old Camp Harney in northern Harney County. 
4. This large generalized area contains nearly all the surviving antelope in Oregon. The number has been roughly estimated here at 2,000 , although it may be considerably in excess of this. They are distributed in many herds, the largest of which is believed to number nearly 1,000 and is located in southern Harney County and southeastern Lake County, from which it may range across into Nevada. Two other herds, estimated to contain about 500 each, range, one in southern Malheur County across the boundary into Idaho and into Nevada, and the other in northern Lake and southern Deschutes Counties. The many dry-farming homesteaders have left the high desert country of southeastern Oregon during the past few years, and the antelope have been gradually going back into their former range. During the summer of 1924, seven grown antelope and one fawn were seen a number of times in the jackpine timber about Button Spring and Sand Spring, where they watered, in the extreme northeastern corner of the Deschutes National Forest. Another recent extension of range is in the vicinity of Fife in southern Crook County and along the upper stretches of Silver Creek in northwestern Harney County.

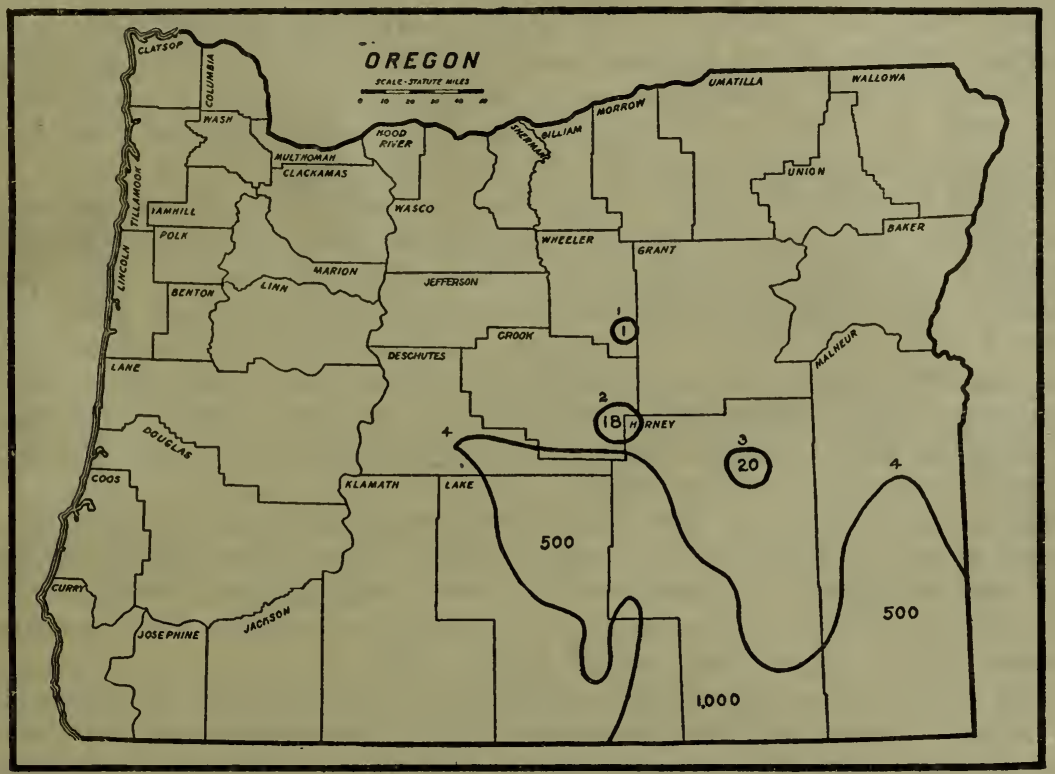

FIG. 14.-Distribution of antelope in Oregon, estimated at 2,039, in 4 areas

There small bands of from 10 to 20 have been seen at various times about Benjamin Lake and on Wagontire Mountain.

The antelope occurring in the northwestern part of their range in this region are scattered in small bands, owing to the extreme scarcity of water. They practically all water at the springs on Grays Butte, Christmas Lake, Button Spring, Sand Spring, and the southern slope of Hampton Butte, and ordinarily at Glass Butte, but the latter spring has been absolutely dry the present season. Antelope in the extreme southeast bordering the Idaho line are in a better watered region and are much scattered along the tributaries of the Owyhee and about many springs in that area.

\section{SOUTH DAKOTA}

Senator Peter Norbeck and State Game Warden H. S. Hedrick are taking a very active interest in the conservation and building up of the herds of antelope in South Dakota. Concerning the practical side of this question, Senator Norbeck's remarks at the antelope conference in Washington on December 14, 1923, are much to the point. He stated: 
"I think the situation in our State is very largely the same as in other Western States. The antelope is exterminated everywhere except in about one-quarter of the area. Together with the State game warden I spent a little time this summer going over 5 or 6 counties and we were surprised that there were a number of small bands of antelope surviving. They remain in certain areas which are probably more favorable for them. The bands were generally from 4 or 5 up to 20 or 30 . One band of 85 was seen-a really fine-looking, healthy lot of animals. They had been ranging in the same neighborhood for about the last 20 years.

"South Dakota is all settled. There is very little Government land left. The land we need for the antelope refuge is nearly all patented, though not all occupied. The State has a fenced game preserve of 40,000 acres, but this is built in the foothills of the mountains and is not a suitable range for antelope. While I was there recently the State game and fish commission passed resolutions taking the first steps toward the establishment of an antelope preserve in the antelope country, with the plan of fencing in 5 or 6 sections of land to include some of the larger bands that we saw during my recent trip. This should take in from 50 to 100 antelope as a start. I am sure that something substantial will come from this."

Senator Norbeck informs the writer that this game refuge will be primarily for antelope, but that with the addition from the Federal forested lands it is desired to establish here herds of elk, buffalo, and possibly some other game animals. The headquarters of this fine game refuge is to be at Reva Gap, located on the main line of an important highway. This locality is not only one of natural beanty but one of historical interest, having been the scene of the battle of Slim Buttes with the Indians 50 years ago, fought under Gen. Anson Mills, then a captain. Parts of this game preserve are hilly, with thin forests; the rest of it is open prairie.

The largest number of surviving antelope are located in the northwestern corner of the State, where, in Harding County, a new State antelope refuge has been established in accordance with legal authorization granted at the time Senator Norbeck was gorernor. In regard to the plans for this refuge Senator Norbeck wrote under date of July 24, 1924 :

"An antelope preserve has been established in the northwest corner county of the State by action of the State game and fish commission, and additional Federal lands have been set aside for the purpose by recent act of Congress.

"The area includes considerable State land, but some private ranches will have to be purchased. The plan is to have an inclosed preserve of about 15,000 acres. The first fence, which is now under construction, incloses an area 3 miles square. It is beliered that from 100 to 150 antelope can be gathered into this inclosure, as that number of animals range over this area and in the immediate neighborhood.

"The State has set aside $\$ 20,000$ for this work. Additional funds will be required, but same will be provided in the next few years. It will probably take from 3 to 5 years to work out the complete plan but I believe that we have made a very good start."

On August 8 Senator Norbeck wrote that after further consideration on the ground it has been agreed immediately to enlarge the fenced area on the new antelope refuge to include $\mathbf{1 5}$ or 16 sections of land.

Under date of September 9, 1924, he added:

"We are going ahead in splendid shape with our antelope preserve. The material has already been purchased for the inclosure of some 15 or 16 sections 
of land. The fenced area will be approximately 4 miles square and will cover some of the present antelope range.

"Whether it will be 15 or 16 sections depends on the purchase of a ranch, for which negotiations are now under way. Most of the land inside the inclosure is owned by the State of South Dakota. An S00-acre ranch, with improvements, located in the center of the area, has already been purchased by the State.

"The inclosure will cover approximately half of the proposed game preserve, it being the intention of the commission to enlarge it in a year or two by adding an area 4 miles square, which will include a few sections of forest-reserve land in the vicinity of Slim Buttes.

"The preserve is located in the eastern part of Harding County and is 84 miles from the closest railroad point by present highways. This, of course, makes the undertaking rather expensive; but it is a splendid location, even though somewhat isolated."

In connection with the establishment of the State antelope refuge in South Dakota, mentioned above, the following letter, dated December 4, 1923, from State Game Warden Hedrick, is worth quoting:

"Senator Norbeck and myself have been making a personal investigation along this line, having recently put in several days in Harding County, in the northwest corner of South Dakota, investigating conditions and looking for a location for the establishment of an antelope preserve, which was authorized by the South Dakota Game and Fish Commission during the time that Senator Norbeck was governor of the State.

"When the Senator arrives at Washington he will doubtless see you personally and paint a word picture to you of this beautiful prairie animal, as he certainly got very enthusiastic when we came upon a band of 85 head on a fine Sunday afternoon and were within 200 feet of a considerable number of these animals at times. Within 3 miles of this place on the same afternoon we came upon another band of 17 and drove up within 8 or 10 rods of them. There was also a band to the west of us that we did not get close to; we do not know how many there were in this band. Upon talking to the neighbors and ranchers in that section, where the antelope seem to have many friends, my estimate would be that there are at least 225 antelope within a range of 4 to 6 townships. There are also many other bands in Harding County, as well as in Perkins, Butte, and Meade Counties. We also have a band of from 50 to 75 head within 50 miles of Pierre, lying to the northwest of us, in the Cheyenne River country. The Senator and I investigated this situation the latter part of July, this year."

Three unsuccessful efforts have been made to stock the large State game park of South Dakota, but in each case the animals died from disease or other causes. The new antelope refuge is in much more suitable country, and there the animals should do well.

On May 29, 1923, Louis Knowles, predatory-animal inspector of the Biological Survey, who furnished most of the information as to the specific distribution of antelope in South Dakota, wrote that he believed antelope have decreased 50 per cent during the year. This has' come about through depredations of predatory animals, diseases, illegal shooting, and a shortage of males. Coyotes are reported to kill many antelope. One of the official hunters has been working in the principal antelope ranges, where he has killed many of these predatory animals, thereby relieving the herds from one of their chief dangers.

On June 23, 1923, Mr. Knowles wrote that stockmen and others throughout the country where the surviving antelope occur report a marked decrease in 
their numbers during the preceding 12 months. The only exception to this is in Harding County, where an increase was reported for the past two years, this possibly being due to animals having come in from other sections. A number of small bands of antelope have been exterminated in the State within the past few years.

Stanley Phillips, present owner of the Phillips buffalo herd, informed Mr. Knowles that antelope in northern Stanley County were rapidly decreasing. He reported the existence of a good-sized band there two years ago, which has since been hunted with dogs and has been rapidly depleted. It is reported that officers who were searching the premises of an alleged "moonshiner" in Harding County found 11 antelope skins. It is encouraging to learn that the people in the town of Buffalo are organizing a rod-and-gun club largely for the purpose of giving protection to the remaining antelope in the Statc.

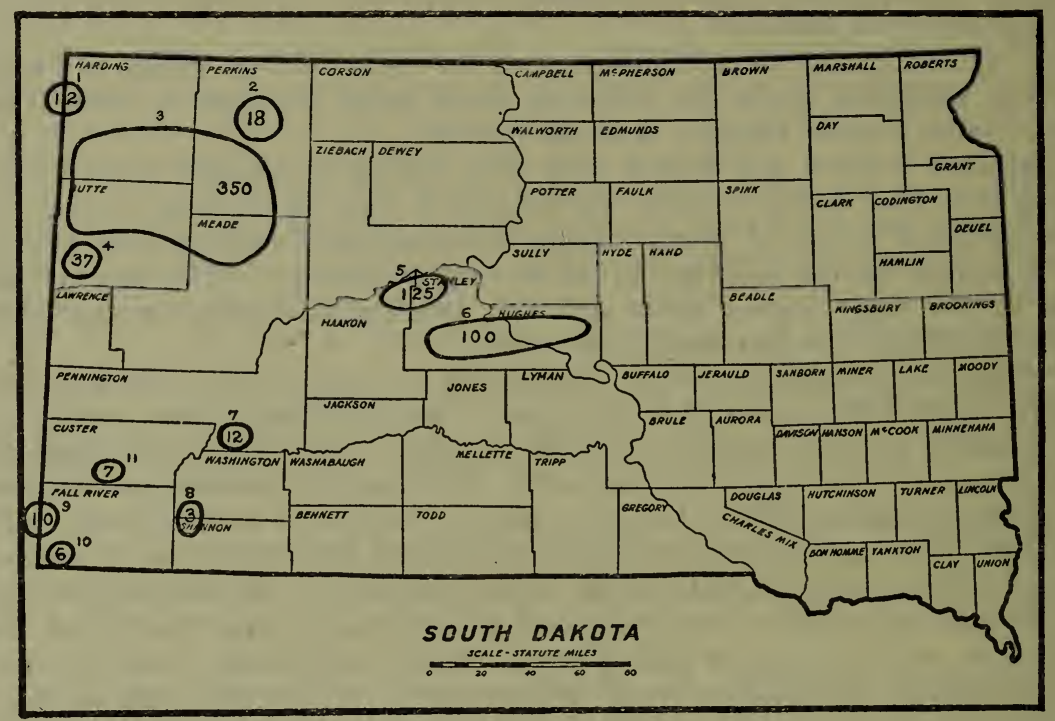

Frg. 15.-Distribution of antelope in South Dakota, estimated at 680, in 11 areas

Mr. Knowles wrote that there has been a disproportionate decrease in the number of buck antelope, and one of the small surviving bands is composed entirely of females. Owing to the scarcity of males throughout the antelope country many of the females do not breed. In one band of 40 only 3 bucks were found.

On June 29, 1923, J. D. Carr, writing from Lindsay, stated that 75 antelope range within a radius of about 8 miles in the Cheyenne Breaks, where they are not being molested. On the same date, from the same locality, F. L. Norman wrote that about 125 antelope are running near Lindsay, where they are so tame that they often come within 100 yards of his home. The crop of young for the season appears to have been large. Mr. Norman states that he and his son try to protect the antelope in every possible way and that they will be pleased to have any measures taken to insure the safety of the herd.

The remaining antelope herds of South Dakota appear to be distributed in the following 11 areas (fig. 15) : 
1. A band of 12 was reported in June, 1923, in western Harding County, probably ranging across the boundary into Montana.

2 . In November, 1923,18 antelope were reported near Bison, in Perkins County.

3. The largest herds of antelope in the State were reported in 1923 by Senator Norbeck and by the Biological Survey representative, Louis Knowles, as existing in adjacent parts of Harding, Perkins, Butte, and Meade Counties. About 150 animals were reported from around Bam Butte. During this same vear $O$. W. Litzke reported having seen about 300 in a 20 -mile ride in the slim Buttes region. In November, 1923, Senator Norbeck wrote there was a herd of 32 in a pasture 3 miles northwest of Camp Crook, and another small herd of 8 in a pasture near Reva Gap, east from Buffalo. Several scattered small bands occur about the north end of Slim Buttes and several large bands about 15 miles southeast of Buffalo, in the neighborhood of Bam Butte, being some 6 miles west of Slim Buttes. Senator Norbeck added: "I saw two small bunches on a quarter section of land, one of about 40 animals and the other about 45. Sereral other bands containing from a dozen to two dozen animals each were seen in a couple of miles in different directions from the larger bands. In other words, there must be from 125 to 150 antelope within 5 miles of Bain Butte, which is a small but well-known landmark in the neighborhood." A reasonable estimate of the total number of antelope in this area is 350 .

4. Thirty-seven antelope are reported to be living on the Belle Fourche Bird Refuge, in southwestern Butte County, in the Paul Bernard pasture, where they are being protected by the owner.

5. About 125 antelope are reported in northern Stanley and eastern Haakon Counties. Concerning these, Senator Norbeck wrote, under date of July 14, 1924 , that he is well pleased with a trip made recently into the Cheyenne River country, and that "careful inquiry among the ranchers who have had a friendly attitude toward the antelope convinced me that there were probably 100 animals ranging over an area 4 miles wide by 10 to 12 long in the breaks on the south side of the Cheyenne River. The distribution seems to be about equal between Stanley and Haakon Counties. It was a surprise to me to find the antelope here, as it did not appear to be choice antelope range, but they have existed here for about 30 years and apparently have held their own."

A band of 30 is probably permanently located on the Carr ranch, in northeastern Haakon County, where there is a pasture about 2 miles wide by 4 miles long, in which the antelope range most of the time, although a year ago last winter they spent several weeks, if not months, on the river flat in an alfalfa field on the ranch. The owner states they did no damage to the alfalfa. Usually they range in the hills and are often seen on high points. Louis Knowles wrote that some appear to be very wild, in part due to the hunting of predatory animals with dogs in this district, during which the dogs frequently pursue the antelope. In addition, there has been a certain amount of hunting with guns. A local hunter agreed that the antelope have not increased here for several years, but during the past three years have about held their own.

6. About 100 antelope were reported in adjacent parts of Stanley and Hughes Counties, where they were decreasing rapidly through being hunted with dogs.

7. Twelve antelope were seen near Scenic, in southeastern Pennington County, in March, 1922 , by $\mathrm{H}$. R. Wells.

8. Only 3 antelope, all females, were reported to survive on the Pine Ridge Indian Reservation, in Washington and Shannon Counties.

9. A band of about 10 was reported in 1923 from western Fall River County. 10. In August, 1924, a bunch of 6 antelope was seen 11 miles west of Ardmore, Fall River County. Antelope have supposedly been extinct in this locality for several years, and it is thought this bunch must have drifted in from the west.

11. In October, 1914, 13 young antelope captured near Brooks, Alberta, were placed on Wind Cave Reserve, the gift of the Boone and Crockett Club, of New York City. (See Pl. VI.) Another shipment of 9 animals from the same source was received in October, 1916. The antelope increased very well, but losses were great, caused partly by sickness and partly by attacks of coyotes. Coyotes have been a source of much trouble and in 1918 killed 13 antelope here. Trappers have been sent to the preserve at various times to assist in exterminating these and other predatory animals and have killed 
a large number of them. The herd is still more or less in danger, however, from attacks of their predatory enemies. It was reduced to 8 animals in December, 1915; increased to 23 in 1917, and to 34 in 1921; but was again reduced during 1922 and 1923 to 17 , and during 1924 to 6 animals, all does. In July, 1924, a young buck, captured in 1923, in northwestern Nevada, was added to the herd, raising the number to 7 .

\section{TEXAS}

Formerly antelope abounded on the plains of western Texas, but with the occupation of the country they hare decreased until it has been possible to obtain definite information of only 42 existing bands, numbering about 2,400 animals, for the entire State. My principal sources of information concerning the antelope in Texas hare been W. W. Boyd, State game, fish, and oyster commissioner, and C. R. Landon, in charge of the predatory-animal work of the Biological Surrey in that State.

On May 1, 1922, Mr. Boyd wrote that the antelope in Texas were ranging so far as possible in the rougher or sandy lands, owing to their haring been hunted in high-powered automobiles. He added that one ranchman in 1922 reported 75 antelope fawns in the herd on his place the preceding year, and that he expected another good fawn crop that spring. Mr. Boyd is taking an actire interest in the remaining antelope in the State and believes that the number can be materially increased. In December, 1924, through his deputies and other sources of information he completed the most thorough census of the surviving antelope in the State that has erer been obtained. The number proves to be much greater than was anticipated.

One of Mr. Boyd's deputies, Pete Crawford, writing on January 12, 1925, stated that a small herd of 4 or 5 antelope which ranged a few miles north of Marathon was completely wiped out. Mr. Crawford added that all the antelope herds that he has mentioned particularly in his report are protected by the ranchmen and popular sentiment. He stated that each of the herds that he personally knows is decidedly on the increase, and he beliered that at the end of 10 years, if the present program of conservation is carried on, antelope herds in the region west of the Pecos will become a common sight.

In the Houston Chronicle for Norember 12, 1923, it is stated from Hebronville that-

" Jim Hogg County perhaps can claim the only remaining antelope in southwest Texas. One herd of 16 to 20 ranges near town on the Hellen and Yeager ranches, while the other herd, somewhat larger, is on the W. W. Jones, Wilbur Allen, and Jonas Weil ranches in the southern part of the county.

"While protected by law and the ranchmen, as far as the latter are able to do so, yet occasionally one is killed by a hunter, as they are as gentle as range cattle and easily shot.

"The adrent of the farmer in this section also is interfering with these beautiful animals and the time is not far distant when, like the buffalo which once roamed orer these prairies, they, too, will have passed."

Apparently the antelope are on the increase in this district, since on January 29, 1925, Mr. Boyd listed herds in that area totaling 285 animals, as indicated in area No. 40 on the map (fig. 16).

H. G. Clark, of Lobo, Tex., writes that coyotes and eagles destroy some of the young fawns, and other causes contribute materially to reduce the increase.

Mr. Landon on April 15, 1922, wrote that 5 or 6 years before he saw between 30 and 40 antelope in one herd ranging near Big Lake, but that last fall the same herd contained only 7 animals. He added: 
"There may be 4 or 5 antelope left on the Bar-S Ranch, north of Barnhart, but I am not certain that even this number survives. A few may exist on the 7-D Ranch or adjoining ranches near Stiles, but $I$ doubt if there are at present 30 antelope in Reagan, Crockett, and Upton Counties, where they were formerly in great numbers. A small herd has existed on the Door-Irey Ranch, 20 miles south of San Angelo, as long as I can remember, but I now understand there are only two left. These I saw about a year ago.

"On the MrIntyre ranch, north of Sterling, there are possibly 20 or 30. Mr. McIntyre protects them as well as he can, but when they get outside of his fence they are usually killed. Sterling and the adjoining counties in all directions except to the east were formerly ideal antelope ranges, but the McIntyre herd is the only one now remaining in that section of the country, and $I$ have been over practically every road in it.

"In the Panhandle a few herds of antelope still remain. On the holdings of the Matador Cattle Co., near Vega, I understand there are two or three small herds. One or more herds are also to be found on the holdings of Lee Bivans, of Amarillo.

"I believe it is conservative to state that where there were 10 antelope in Texas 10 years ago there is now less than one. In the country near Big Lake they suffered the greatest loss one fall three or four years ago, when through an oversight the legal protection of antelope in Texas was allowed to lapse for about 30 days. During this open season they were run down by men in motor cars and hunted so closely that the herd was practically exterminated. On the ranches near Amarillo, which were mainly posted, antelope would probably have held their own so far as human agencies were concerned, but the extremely severe winter of 1918 , when the snow remained on the ground for weeks at a time, killed them by hundreds, and only a handful survive."

In a letter dated Jume 17, 1923, Charles Goodnight wrote that at one time he captured 5 antelope and placed them in one of his fenced pastures near Goodnight, where they increased to 18 , after which all were killed by hunters. He added that in his opinion antelope will not live in small inclosures but do well where they have plenty of room.

In the following summary of existing antelope in Texas all the reports are as of December, 1924, unless otherwise stated (fig. 16) :

1. Band of 6 reported in Hansford County.

2. Band of 3 reported in Ochiltree County.

3. In 1922, 25 antelope were located on the Sheldon range in Oldham and Hartley Counties, and a band of 4 on the Bivins ranch, near Channing, Hartley County. In December, 1924, the State game department estimated 350 for the entire county.

4. In 1923 there was a band of 5 in the breaks of Moore County; these are now estimated to number 25.

5. A band of $\mathbf{1 6}$ is reported from Hutchinson County, apparently about maintaining its numbers.

6. Forty were reported in 1924 in Roberts County.

7. In 1922 a band of 7 were living on the Landergin West ranch, near Adrian, Oldham County; in December, 1924, 125 antelope were estimated to exist in this county.

8. In 192260 were reported in the Brown and Trujillo pastures, near Amarillo, Potter County; in December, 1924, only 20 were estimated to be found in this county.

9. Twenty-five are estimated to be living in Carson County.

10. Deaf Smith County is estimated to contain 100 antelope.

11. A band of 10 is reported in Randall County.

12. Fifteen were reported in Castro County in 1924.

13. In 1922 a band of 15 was reported on the Francis Miller ranch in Bailey County; in 1924 a total of 50 was estimated in this county. 
14. A band of 9 was reported in 1923 on Spring Lake ranch, Lamb County ; in December, 1924,30 were estimated in this county.

15. One hundred antelope were estimated in the fall of 1924 in Cochran County.

16. Seventy-fire are reported in Hockley County.

17. A band of 10 is reported in Lubbock County.

18. Five antelope are reported in Kent County.

19. In the spring of 1924 a band of 5 was reported about 18 miles west of Seminole, and another band of the same number about 16 miles west of Seagrares, Gaines County; in the fall of that year the total number in the county was estimated at 30 .

20. A band of five is reported in Borden County.

21. A band of five is reported in Scurry County.

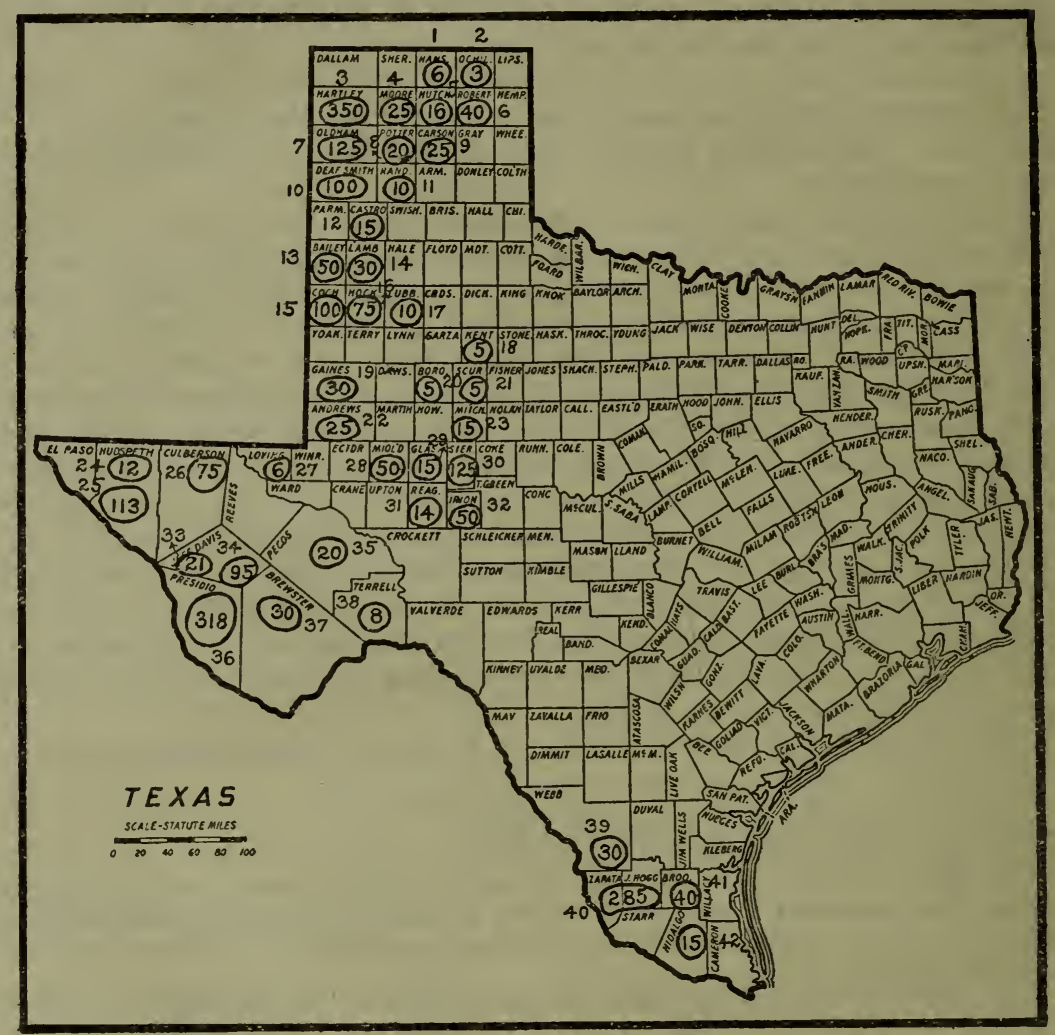

Fig. 16.-Distribution of antelope in Texas, estimated at 2,407, in 43 areas

22. 'Twenty-five are reported in Andrews County.

23. Fifteen are reported in Mitchell County.

24. In 1922,10 to 12 were reported as ranging in northern Hudspeth County, southwest of Orange, N. Mex.

25. Several small bands, aggregating about 65 antelope, were reported in 1922 as occurring in central Hudspeth County. A. E. Gray, in charge of the rodent work of the Biological Survey in Texas, writes that the consensus of opinion among ranchmen is that these animals are gradually decreasing. The stockmen state that, in addition to the antelope killed by local residents, numbers are killed by hunters from El Paso who make annual trips into that country during the deer season. In the fall of 1924, however, the State game department estimated a total of 125 antelope in Hudspeth County; in the absence of details as to their distribution it may be assumed that this indicates an increase in herd No. 25. 
26. In 1922 , 75 were reported on the W. D. Casey ranch in northeastern Culberson County.

27. A band of six was reported in Loving County in 1924.

28. Fifty were reported in Midland County in 1922, but the present status of the band is not known.

29. Fifteen antelope were reported in Glasscock County in $\mathbf{1 9 2 4 .}$

30. In 1922 about 30 were living on the McIntyre ranch, north of Sterling; in the fall of 1924, 125 were estimated in Sterling County.

31. A band of 7 was reported in 1923 near Big Lake, Reagan County; in the fall of 1924, 14 were reported in this county-probably the same band.

32. Fifty were reported in 1924 in Irion County.

33. In 1922,13 antelope were reported six miles north of Valentine, and 8 on the Jones Ranch, in northwestern Jeff Davis County; no later report concerning these has been received. In 1924 reports give 21 in the western part of the county.

34. A herd of 20 was reported in January, 1925, ranging on a ranch five miles southwest of Fort Davis. About 75 head were reported also, scattered in small herds, on the H. L. Kokenot ranch along the border line between Jeff Davis and Brewster Counties.

35. In 1922 sereral small bands were reported east and south of Fort Stockton, Pecos County, and in 1924 about 20 antelope were reported in this area.

36. About 300 antelope were reported in 1924 to be living on the Fisher ranch, 17 miles southwest of Marfa, in Presidio County; these animals are rigidly protected by the owner. On the Cardwell ranch, seven miles west of Marfa, there is a herd of about 18 head.

37. A herd of about 25 is located about three miles northeast of Alpine, Brewster County, in one of $\mathrm{H}$. K. Kolrenot's pastures, the animals being carefully protected by the owner. A band of four or five ranges near Altuda in the same county.

38. A band of eight antelope is known to range between Dryden, Terrell Counts, and the Rio Grande, the band having increased from three animals in 1922 .

39. Thirty antelope were reported in the fall of 1924 in Webb County, but the exact locality was not stated.

40. In January, 1925, State Deputy Game Warden O. R. Stephens reported sereral bands, aggregating about 285 antelope, as ranging mainly in Jim Hogg and Zapata Counties, as follows:

"On the W. H. Yager ranch, situated in the corners of Jim Hogg and Webb Counties, there is a band of antelope numbering 35 head, 17 of which were counted as fawns the past summer. On the W. W. Jones ranch, located in the eastern part of Jim Hogg County, there is a band of about 150 head, 40 of which were counted as fawns last summer. Another band of 40 lives on the Jonas Wiles ranch in the southeast corner of Jim Hogg County, and another of 60 head on the Wilbur Allen ranch in the south part of Jim Hogg County."

41. Forty antelope are reported from Brooks County.

42. Fifteen are reported by the State game department from Hildago County.

UTAH

Antelope were once plentiful and widely distributed over the greater part of Utah. Gradually they have been reduced in numbers until now we have been able to learn of survivors existing in 10 sections of the State, numbering about 670 animals. The information has been mainly obtained through the efforts of George E. Holman and B. B. Richards, in charge, respectively, of the predatory-animal and rodent-control work of the Biological Survey in the State, with the assistance of D. H. Madsen, State game warden. Owing to the size of the State and to the fact that the surviving animals occur mainly in the sparsely settled districts, it has been exceedingly difficult to gather accurate information as to the exact number of these animals, but it is believed that there are few additional to those here reported. Mr. Madson has expressed interest in the conservation of the antelope, and on December 8, 1923, wrote: 
"During the past few months we have interested the Union Pacific Railroad Co., which is at present working out plans for the development of the Zion Park and Bruce Canyon scenic attractions, and which has agreed to give us all the cooperation possible in the protection of the antelope."

The information appears to indicate that the antelope in Utah are rapidly decreasing. Very definite and prompt efforts will be necessary to prevent their complete extermination. It is to be hoped that local game-protective associations and others will make special efforts to safeguard the few widely scattered surviving bands. It is gratifying to note that in certain areas, as on the Escalante Desert, in Iron County, the settlers are interesting themselres in antelope protection. Unfortunately, reports from remote districts indicate that

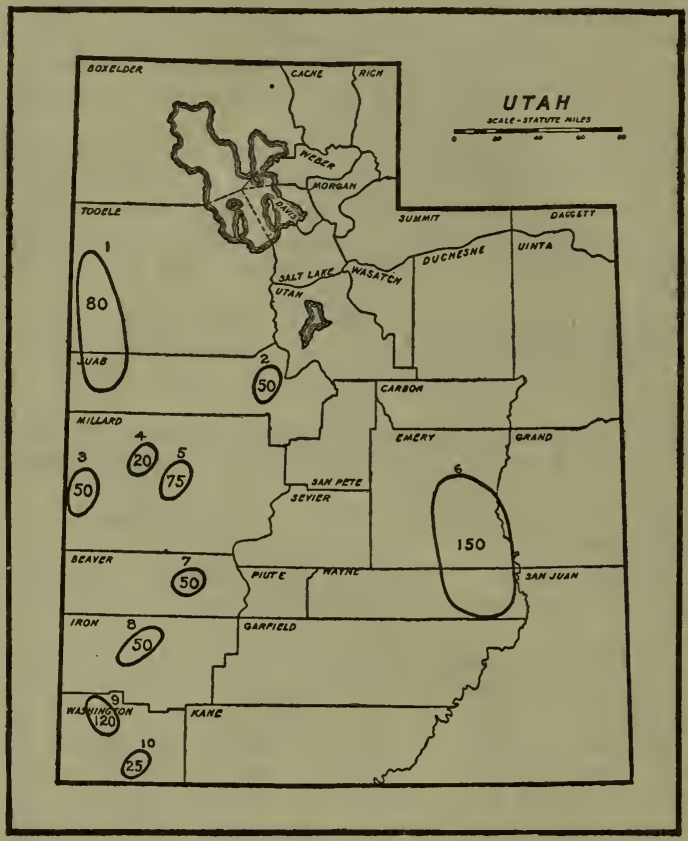

FrG. 17.-Distribution of antelope in 'Utah, estimated at 670 , in 10 areas

herders make a practice of killing these animals when opportunity offers.

The antelope in Utah are distributed as follow's (fig. 17) :

1. In 1922 a band of about 50 was ranging in the vicinity of Erickson, in Tooele County, where they were reported as being killed, especially in winter, and in danger of extermination. Another band of:30 was ranging from Callao, in Juab County, to Guld Hill, in the same county.

2. A band of 50 was reported in 1922 as ranging in the vicinity of Cherry Creek, in Juab County, where they were said to be maintaining their numbers.

3. In 1922 a band of 50 was reported in Snake Valley, Millard County. These are the survirors of the herd of about 200 there in 1919. Their decrease is attributed both to their being hunted and to the inroads of predatory animals.

4. In 1922 a band of about 20 was reported in White Valley, Millard County. 5. In 1923 a band of not less than 75 was reported in the vicinity of Serier Lake, in Millard County. This is said to be increasing.

6. Several bands aggregating about 150 animals were living in 1923 on the desert in Emery and Wayne Counties, ranging thence down to the Green River breaks. A few were reported on the east side of the Green River, in Grand County.

7. In 1922 about 50 were reported in the vicinity of Milford, in eastern Beaver County.

8. About 50 antelope are reported to live on the desert between Lund and Cedar City, in Iron County. Travelers on the road between these two places not uncommonly see some of these animals. As many as 50 have been seen on one trip. The settlers are interested in their protection and the antelope have become very tame. L. L. Carter, who has been long familiar with that region, states that in 1919 there were about 250 antelope there. After a period of heavy decrease it is believed that under the present protection they are now increasing.

9. About 100 antelope were reported in 1922 as about maintaining their numbers in Hamblin Valley, northwestern Washington County. Another band of 20 is reported from Pine Valley, in the same county, concerning which 
Mr. Carter states that predatory animals and shooting have caused a reduction from about $50^{-}$present in 1919.

10. In 1922 a band of 25 was reported in Hurricane Valley, Washington County.

\section{WYOMING}

Wyoming has the distinction of possessing the largest number of antelope surviving in any State. This, however, is only a pitiful remnant of the vast numbers which once roamed its great open plains. Antelope are now reported from 27 sections and total 7,000 . In 1885 on the Big Sandy River they were estimated to number about 30,000 , or as many as now survive on the whole continent.

Practically throughout the United States, as in Canada and Mexico, there is now a close season on antelope. A modified exception to this rule exists in Wyoming, where an act approved February 18, 1921, which still remains in force, reads as follows :

"Whenever, in the judgment of the State game and fish commission it is deemed desirable, the said commission may direct the State game and fish commissioner to issue not to exceed one hundred special buck antelope permits."

Owing to the numbers of antelope in some sections of Wyoming in 1922, plans were made for the issuance of 100 buck-antelope licenses under this law, but so strong was the public opposition which developed that the idea was abandoned.

The history of the Greybull River herd on the Pitchfork Ranch and vicinity, above Meeteetse, is a good illustration of the manner in which an antelope herd may be built up and also demonstrates the fact that a great increase of game under protection in the midst of a cultivated district may become detrimental to the interests of the farmers and lead to open antagonism toward the animals. The late L. J. Phelps, one of Wyoming's pioneers, living at Meeteetse, many years ago realized that the antelope were disappearing. In 1902 he declared that no antelope should be molested anywhere on his holdings and prohibited shooting. At that time there was a band of about 15 ranging in the vicinity of the Pitchfork Ranch. Through Mr. Phelps's influence during the next 21 years the original 15 increased to about 1,500. During 1923, Charles J. Bayer, in charge of the predatory-animal work of the Biological Survey in Wyoming, visited the Pitchfork Ranch to investigate this herd, and reported that there were practically 1,000 antelope ranging within the boundaries of the territory of area No. 3 on the accompanying map (fig. 18). They were broken into bands of from 25 to 125 each. It is planned to verify the numbers by a count during the fall of 1925. Eugene Phelps, in charge of the Pitchfork Ranch holdings, reports to Mr. Bayer that during the past two years the animals have increased to such an extent that they have become a pest. They enter grainfields after harvest and consume much grain before it can be hauled in and threshed; they also graze throughout the year on lands owned and leased by his company. He contends that the antelope consume sufficient forage from their holdings to accommodate easily a good-sized band of sheep, and this contention appears to be correct. Many of the antelope were grazing in the pastures and fields at the time of this investigation.

A. M. Hogg, representing the Hogg brothers' land holdings in that vicinity, reports that their company has suffered considerable loss of forage through the antelope. He states that during the past four years the antelope have cleaned all the forage from one field of 160 acres. Immediately after a heavy snowstorm on October 24, 1923, a band of between 500 and 700 crossed the fence into an alfalfa and grain field and consumed about half the second crop of forage. They also visited the grainfields at night and destroyed some 
grain and ate hay in unfenced stacks but without much damage. With the melting of the snow and the return of favorable weather three weeks later, the antelope left the ranches for the outside range.

It is reliably reported that after a heavy snowstorm in October, 1922, about 500 antelope drifted out of the Meeteetse Valley into the farming country around Burlington, where the farmers shot large numbers, keeping the band moving in an easterly direction until they crossed the Big Horn River. It is impossible to learn how many animals were killed before they crossed the river, but everything indicates that at least half of the band was hung up in meat houses along the way. As near as can be ascertained the survivors did not return.

Eugene Phelps, A. M. Hogg, and Forest Supervisor Andrew Hutton suggest that a limited-license system should permit killing 50 to 100 buck antelope for each of the next two years, in this way ridding the range of many old animals. According to their statement there are twice the number of bucks really needed for the welfare of the herds, and this recommendation was made with the belief that such killing would cause large bands to split and spread into the adjoining areas, thus avoiding their congestion in one central district. If after a couple of years it should be found that the antelope have been properly distributed and are not in sufficient numbers to cause material damage to crops, then the season could be closed again.

The census of antelope in Wyoming has been compiled mainly by Albert M. Day and Charles J. Bayer, of the Biological Survey, with the cooperation of Frank S. Smith, State game warden.

The distribution of the antelope in the State is approximately as follows (fig. 18) :

1. The Yellowstone Park herd comprises the antelope which in summer frequent the plains of the upper Yellowstone River, within the boundaries of the Yellowstone Park. During severe winters, particularly when the snowfall is heavy, they have generally been forced to descend along the valley of the Yellowstone River to lower country in Montana. In 1909 the Yellowstone Park antelope herds were estimated to number about 2,000 animals. The last heavy loss occurred in the winter of 1921-22, when the deep snow made it difficult for them to escape the depredations of coyotes and wolves, and others perished from starvation. In the spring of 1922 only 235 remained. Horace M. Albright, superintendent of the Yellowstone National Park, to whom the writer is indebted for the information concerning this herd, in a letter dated September 10,1924 , stated that during the summer of 1923 approximately 70 fawns were born, of which all but 5 survired the following winter. In the spring of 1924 there were approximately 320 antelope in the herd. Reports from the summer range indicate that a large number of fawns were born, and in December, 1924, Mr. Albright reported 410 antelope in the park herd. He arranged to feed and safeguard the animals during the winter of 1924-25. The decrease in numbers in this herd through a series of years appears to have been brought to an end under Mr. Albright's guardianship.

2. In this area about 80 antelope range along the Shoshone River, in Park County.

3. One of the largest single herds in the State is reported ranging on the Greybull River, in southern Park County. It is estimated to contain approximately 1,000 animals and to be increasing. Further details concerning these are given above.

4. There are about 100 antelope southwest of Burlington, in Big Horn County.

5. Bands estimated to number 200 range in the Stagner and Black Mountains and on Owl Creek, Hot Springs County.

6. About 150 antelope are located near Kaycee, in Johnson County, where they are said to be decreasing rapidly.

7. A band of about 60 is reported on Wattel and Hanging Woman Creeks, in northeastern Sheridan County. 
8. About 130 are reported about 7 miles southwest of Gillette, in Campbell County. These are said to be fast decreasing as a result of hunting.

9. In this area approximately 350 antelope range on the Belle Fourche River, in Campbell County. Their numbers are reported to be rapidly decreasing through shooting.

10. About 60 antelope are reported along the Little Missouri River and the North Fork of the Cheyenne, in Crook County. These animals undoubtedly range back and forth across the border into Montana. They are reporter to be rapidly decreasing.

11. One hundred and fifty antelope are reported to range on Lodge Pole, Prairie Dog, and Black Thunder Creeks and Cheyenne River in Weston County.

12. About 300 range along Antelope, Bear, and Sand Creeks, in northern Converse County.

13. Three bands, totaling about 70 , appear to be generally scattered over the northern half of Niobrara County.

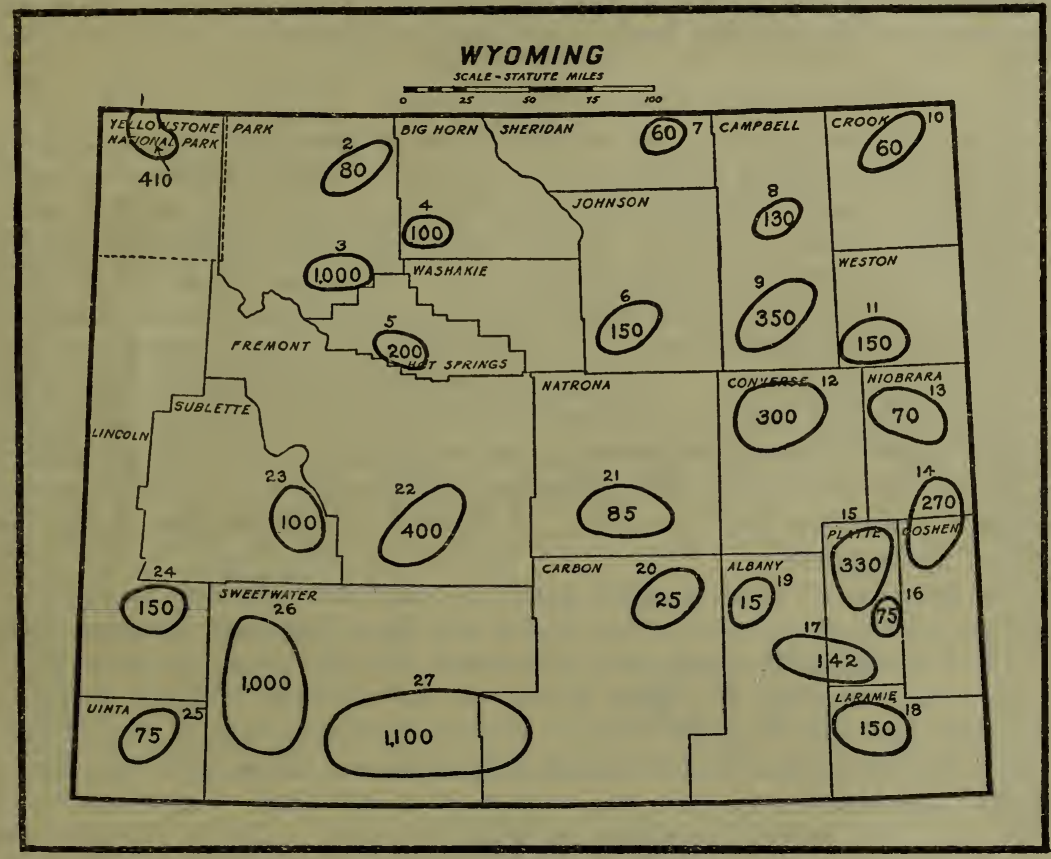

FIG. 18.-Distribution of antelope in Wyoming, estimated at 6,977, in 27 areas

14. In southern Niobrara County is a band numbering about 180 , and there are 90 near Raw Hide Butte, in northern Goshen County. These herds appear to be about holding their own.

15. This area, covering part of northern Platte County, is reported to have about 330 antelope, in two bands of 150 each, ranging on Glendo and Flat Top Creeks and Laramie River, and one band of 30 on Fish Creek.

16. This area, in middle eastern Platte County, is reported to have about 75 antelope, mainly about Goshen Hole and Deer Creek, near Wheatland.

17. In the middle eastern part of Albany and southern Platte Counties there are about 142 antelope, made up of three bands, numbering, respectively, 12, 45, and 85, ranging on Sibylee, Antelope, and North Chugwater Creeks. These are reported to be decreasing as the result of shooting.

18. About 150 antelope are reported as ranging on Horse and Bear Creeks, in Laramie County. These are said to be decreasing rapidly.

19. A band of 15 lives on Mule Creek in northern Albany County near Marshall. 
20. About 2.5 are reported in Shirley Basin, in northeastern Carbon County.

21. A band of 85 is reported in Natrona County, along Powder River and Bates, Poison Spider, and Fish Creeks.

22. This area contains about 400 antelope ranging on the Sweetwater Divide, in Freemont County.

23. One hundred antelope are reported on Big Sandy Creek and New Fork of Green River, in Sublette County.

24. About 150 are reported near Fontenelle, in Lincoln County. They are said to be decreasing rapidly through shooting.

25. About 75 occur on Middy Creek, in Uinta County, where they are said to be rapidly decreasing.

26. In the Green River Valley, in western Sweetwater County, about 1,000 antelope are reported, which makes it the second largest herd, and gives Sweetwater County a total of 2,100 antelope (see area No. 27), by far the largest number surviving in any county in the State.

27. This area is reported to include about 1,100 antelope, the largest number in any similar area in the State. It lies mainly in southeastern Sweetwater County, extending into the adjoining part of Carbon County. The main bands range on Black Rock, Shell, Skull, and Lost Creeks.

\section{CANADA}

In Canada antelope are now limited to the Prorinces of Alberta and Saskatchewan. In Alberta bands are located in 5 areas, containing a total of about 1,030 animals. In Saskatchewan they are located in 9 areas in which are about 297 animals, or a total of 1,327 north of the United States. Antelope formerly ranged east into Manitoba and north to the limit of the plains along the Saskatchewan River. For some years the antelope in Canada dininished rapidly, but are reported now to be about maintaining their numbers or eren increasing in some areas. Althougl the conservation of antelope in Canada is mainly a matter for the attention of the Provinces, yet the Dominion Government assumes general responsibility in regard to all wild life, particularly concerning the antelope. The Canadian National Park at Nemiskam was especially created for their protection. J. B. Harkin, commissioner of Canadian national parks, states:

"The question of creating other parks as sanctuaries is now receiring the attention of the department. Our efforts are being retarded, howerer, owing to lack of appropriations necessary to proceed with the work. A limited number of young antelope are being raised on the national antelope refuge at Nemiskam and will be transferred to Buffalo National Park at Wainwright, Alberta, as soon as they are old enough to be shipped. These, with the antelope already at the park, will form the nucleus of a new lierd. I think it can be safely said that, due to the efforts put forth in recent years for the protection of these animals, they have not seriously decreased and are now holding their own."

Concerning the heary losses of antelope which were reported to have taken place by their drifting against fences along the railroad in this region some years ago, F. Bradshaw, game commissioner of Saskatchewan, writes that no serious recent losses of this kind have occurred, but that he read an article not long ago by Doctor Prince in Rod and Gun in Canada, in which reference was made to thousands of animals dying along the fence of the Canadian Pacific Railway west of Swift Current.

For the information concerning the surviving antelope in Canada the writer is indebted to J. B. Harkin, commissioner of Canadian national parks; to F. Bradshaw, game commissioner of Saskatchewan; and to Benjamin Lawton, chief game warden of Alberta.

The distribution of the herds is as follows (fig. 19): 


\section{ALBERTA}

1. About 500 are reported on the north side of Bow River above its junction with Lethbridge or Belly River, west and south of Brooks, on the Canadian Pacific Railroad.

2. About 100 range on Red Deer and South Saskatchewan River's, a short distance west of their junction.

3. About 100 are reported in the section between Belly River and Bow River, to the northeast of Lethbridge.

4. On the National Antelope Refuge in Nemiskam, to the west of Iuake Pakowski, 180 antelope were reported in September, 1924.

5. The latest information, in 1924, gives about 150 as ranging in the extreme southeastern corner of the Province.

\section{SASKATCHEWAN}

6. About 40 antelope are said to range on both sides of the South Saskatchewan River, west of Owensville.

7. To the northeast of White Bear Lake about 20 antelope are said to range.

8. A band of 8 antelope is reported on the South Saskatchewan River a few miles west of Saskatchewan Landing.

9. Between White Bear and Luck Lakes, some distance north of the South Saskatchewan, 12 antelope are reported.

10. A band of about 10 are reported near Long Valley, northwest of Lake Chaplin.

11. About $100 \mathrm{range}$ about Bigstick Lake, north of Maple Creek on the Canadian Pacific Railroad.

12. To the north of $\mathrm{Cy}$ press Lake, in the southwestern corner of the Province, 40 antelope are reported.

13. On the north side of Frenchman Creek, near the town of East End, 27 are reported.

14. About 40 are re-

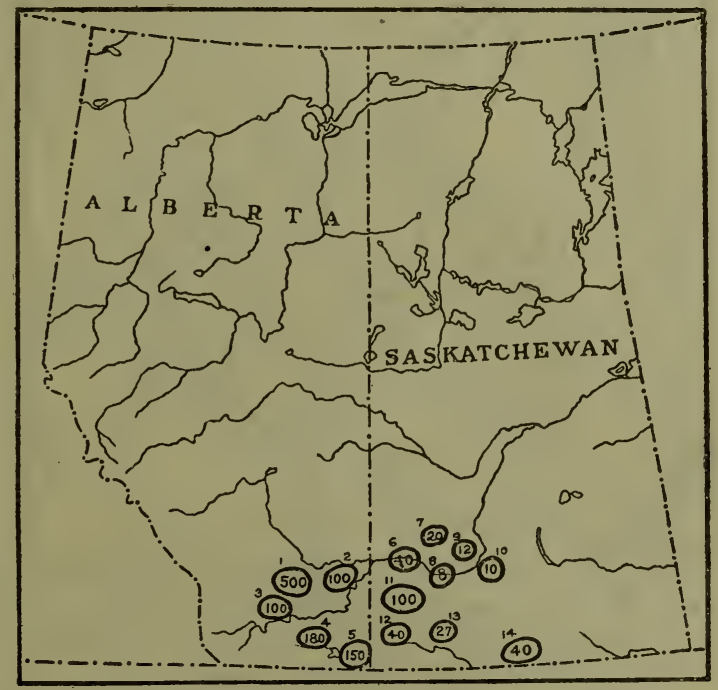

Frg. 19.-Distribution of antelope in Canada, estimated at 1,030 in 5 areas in Alberta, and 297 in 9 areas in Saskatchewan; a total of 1,327 in 14 areas ported to occur in the area south of Wood Mountain, drained by Freuchman Creek and Poplar River, both tributary to the Missouri.

\section{MEXICO}

It has not been possible to obtain definite information concerning the distribution of the antelope bands or the numbers contained in them from any part of Mexico except Sonora. The accompanying maps (figs. 20 and 21) and statements concerning the surviving antelope in that country are based on personal knowledge of the writer and on information mainly received from Carlos Lopez, in charge of the Federal game administration of Mexico, and from Game Warden Ben Tinker.

Formerly antelope ranged south over the great Mexican tableland to within less than 100 miles of the City of Mexico. It is interesting to know, as set forth earlier in this report, that the first mention of antelope seen by Europeans 
on this continent was recorded in an account of a great hunt organized for the viceroy of Mexico in 1540 , at a point near the present station of Cazadero on the Mexican Central Railroad in extreme southwestern Hidalgo.

The main herds of antelope in Mexico are undoubtedly located on the broad arid plains of Coahuila, Chihuahua, and northeastern Durango. Other herds occupy considerable territory in northwestern Sonora, some occasionally ranging back and forth across the border between Sonora and Arizona, and others are located in Lower California. From information received it appears possible at this time that, in general, antelope may be holding their own in Mexico.

On October 1, 1922, a close season of 10 years on antelope, which had been established by President Obregon, became effective. This should serve to lessen the number of these animals killed and so favor their increase. There

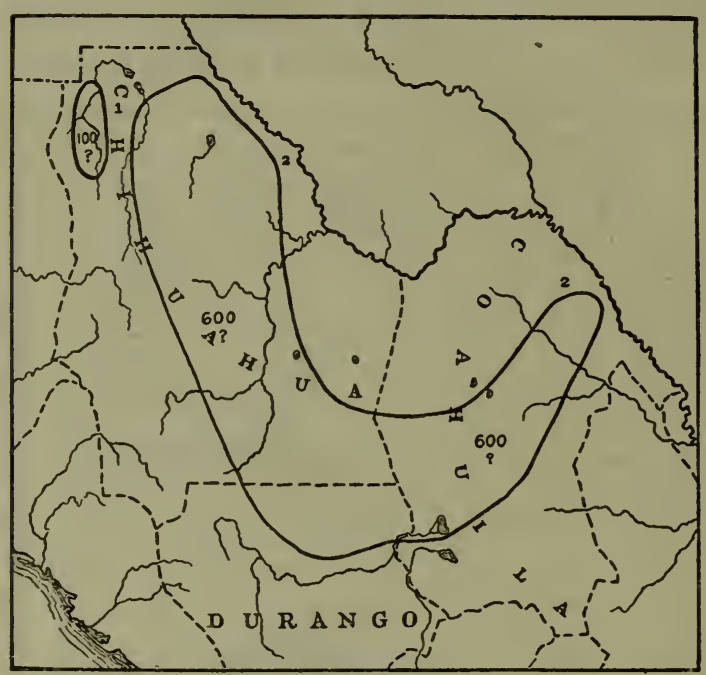

Frg. 20.-Distribution of antelope in parts of Mexicoin Chihuahua, Coahuila, and Durango, estimated at about 1,300 in 2 areas (see also fig. 21) are great areas of sparsely occupied plains on the northern Mexican tablelands where they might find a home far into the distant future.

To assist in safeguarding the antelope and other game animals of northern Sonora the Permanent Wild Life Protection Fund, through Doctor Hornaday, has entered into an agreement with the Mexican Government whereby it employs Ben Tinker as game warden, with headquarters at Tucson, Ariz., to work along both sides of the Arizona-Sonora border to prevent poaching.

It is conservatively estimated that there are 2,395 antelope in Mexico, of which 1,300 are estimated to be in Chihuahua, Durango, and Coahuila, and 500 in Lower California. The remainder are more definitely known in Sonora. These numbers will serve as a working basis until there is opportunity to get more complete information. It is probable that there may be many more on the plains of Chihuahua and Coahuila than here estimated. The following details of distribution are based on a letter received from Professor Lopez in January, 1924, and from other information available on the subject. It is grouped under States and the Territory of Lower California, as follows (figs. 20 and 21) :

\section{COAHUILA}

In the great Valley of La Encantada, to the west of Muzquiz, bands of 50 to 100 antelope occur. They are also about the Hacienda de San Antonio, and are more abundant about the Hacienda de Paila and on the plains about the neighboring mountain range of Espianzo. Most of the antelope in Coahuila are located west of the railroad which runs south from Eagle Pass, Tex., to Saltillo, and north of the railroad extending from the last-named place restward to Torreon. 


\section{CHIHUAHUA}

In extreme northwestern, southeastern, and eastern Chihuahua antelope occur in varied numbers. The bands in the extreme northwestern part are separated from those which range along the Mexican Central Railroad to the east. The great Bolson de Mapimi and the region east of the Mexican Central Railroad is a vest territory ideally suited to the needs of these animals. In southern Chihuahua antelope occur on both sides of the Mexican Central Railroad, particularly along the border of Durango.

DURANGO

In Durango antelope are now limited mainly to the northeastern part of the State, in the district of San Dimas. Antelope are reported to be rather common in the following localities : L a pi o r i z, Maravelles, El Pilar, Santa Rita, San Julián, Las Lagunas, Huachinepas, San Francisco de los Lobos, Pericos, and Huahiapa $\mathrm{y}$ Gavilanes. They are also said to be abundant in the district about Escalon, along the border of Chihuahua and Durango, near the base of the Sierra del Diablo.

\section{SONORA}

Antelope in Sonora are practically all west of the railroad extending from Nogales on the Arizona border south to Guaymas and in the region lying north of a line drawn from Hermosillo west to the coast of the Gulf of California. A few bands in

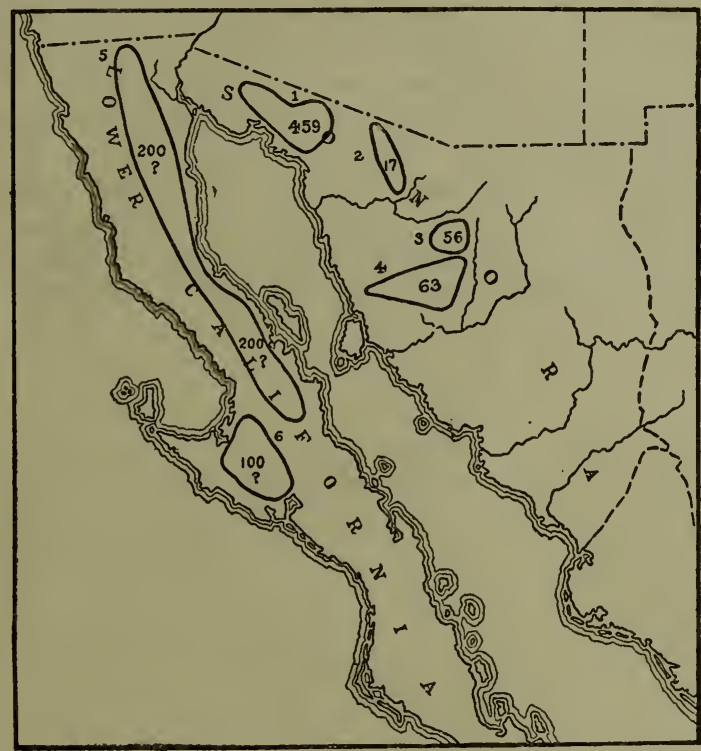

Fig. 21.-Distribution of antelope in Lower California and Sonora, Mexico, estimated at 500 in 2 areas of Lower California, and 595 in 4 areas of Sonora; a total of 1,095 in 6 areas (see also fig. 20)

\section{northwestern Son or a}

range back and forth across the Arizona border. It is these bands which are now under the guardianship of the Permanent Wild Life Protection Fund.

Under date of January 4, 1925, Ben Tinker, who represents the Permanent Wild Life Protection Fund along the Sonora-Arizona border, supplied the writer with interesting information concerning the distribution of the surviving antelope in Sonora. They are reported to occupy 4 areas and to have totaled 595 animals in November, 1924, when they were counted by him. Following is his summary of these antelope herds:

1. Comprises numerous bands, numbering 459 all told, ranging from the southern end of the Sierra Rosario south and east to the Sierra Blanca and the Rio Sonoyta, thence eastward (north of Sierra Pinta) to the eastern side of the Sierra de San Francisco. The largest single band, containing 73 animals, ranges between the Sonoyta River and Sierra de San Francisco during the months of October, November, and December and southward from this river to the Sierra Pinta during the remainder of the year. 
2. Comprises $\mathbf{1 7}$ in two bands between the Sierra de la Nariz and the town of Altar.

3. Comprises 56 in small. scattered bands from Sierra del Cajon eastward to within six mlles of Noria Station on the S. P. de M. Railway.

4. Comprises 63 in mans small bands between the Rio San Ignacio and the cits of Hermosillo.

\section{LOWER CALIFORIIA}

Antelope in Lower California are distributed mainly on the plains east of the central mountain range from the California border south to the middle of the peninsula. They are also on the desert of Vizcaino, where thes lire rest of the main mountain range, reaching the borders of the Pacific on the shores of Vizcaino Bar on the north and Ballenas Bar on the south. It is estimated that not less than 500 antelope surrire on the peninsula. Formerly antelope in Lower California ranged south berond Magdalena Bay, but for mans sears thes hare been extinct orer a large part of their former territory. During the past 15 rears antelope hare been continuousls hunted in Lorrer California. and it is rather surprising that ther hare continued to surrire. It is hoped that the operation of the present close season on them mas result in their numbers again increasing. Natural conditions are such that Lower California will nerer be densely populated or occupied by farming communities of ans importance. Tater is scarce in the interior, and great plains corered with desert regetation afford an ideal home for antelope. With reasonable protection ther might survive there in large numbers far into the future (fig. 21).

ADDITIONAL COPIES

OF THIS PUBLICATION MAY BE PROCCRED FROM

THE STPERTIENDENT OF DOCTMENTS

GOTERNMENT PRINTING OFFICE

WASHINGTON, D. C.

$\Delta \mathrm{T}$

15 CENTS PER COPY 


Photomount

Pamphlet

Binder

Gaylord Bros.

Makers

Syracuse, $\mathbf{N}$. Y.

PAT. JAN 21, 1908 


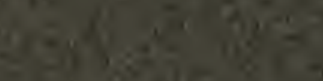

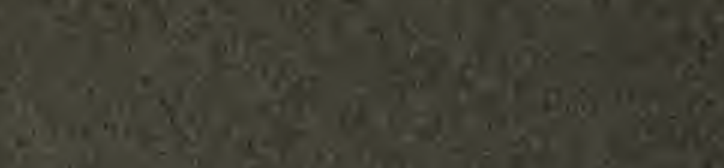

3

Cus

$16+15$

$4=$

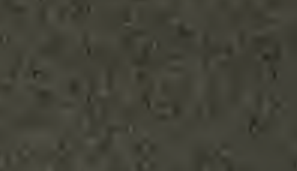

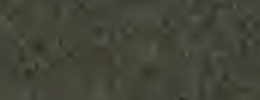

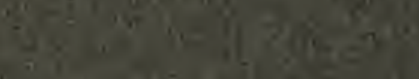

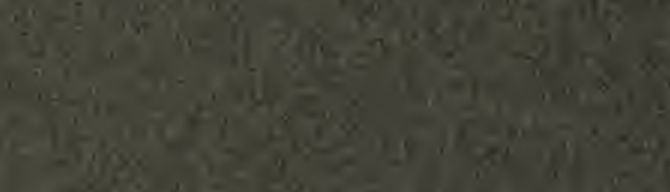

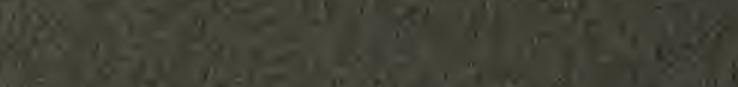

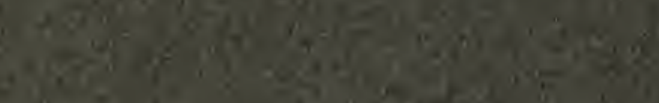

$=x^{2}+3$

$(x+5)$

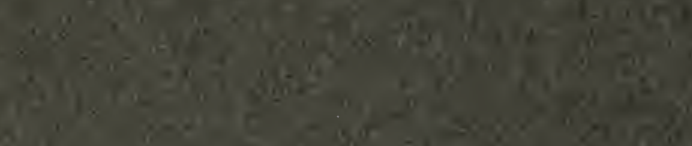

$=\frac{1}{4} \div \frac{1}{2}=$

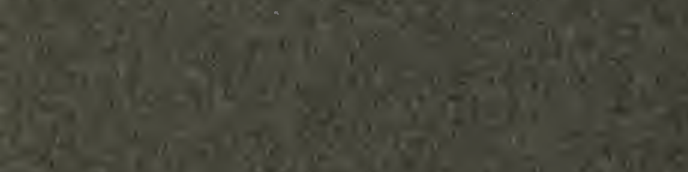

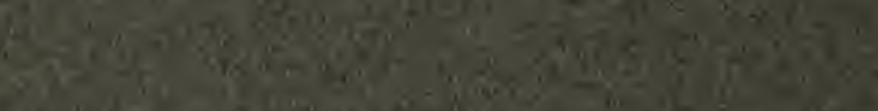

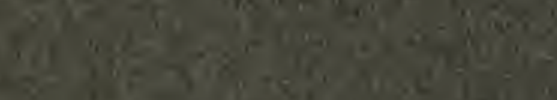

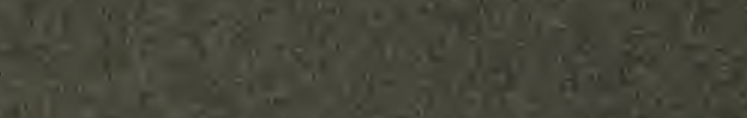

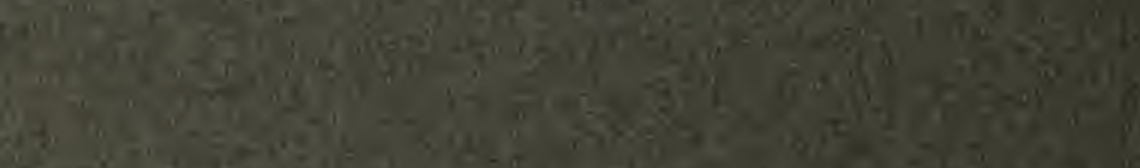

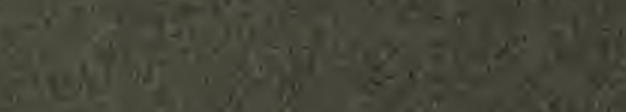

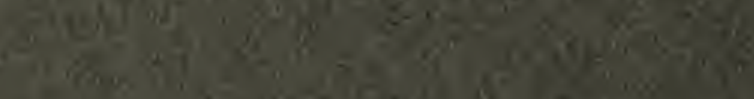

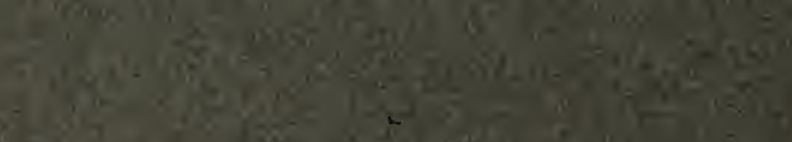

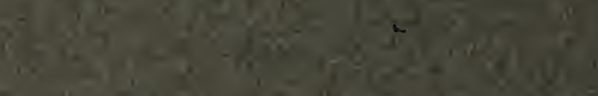

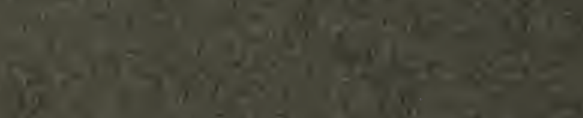

